\title{
Coordination Chemistry of Nitric Oxide and Biological Signaling
}

\author{
José A. Olabe \\ INQUIMAE (UBA-CONICET), Facultad de Ciencias Exactas y Naturales, Universidad de Buenos Aires, Argentina. \\ E-mail: olabe@qi.fcen.uba.ar
}

Dedicated to Prof. Wolfgang Kaim in his 70th birthday

\begin{abstract}
Nitric Oxide (NO) is a key intermediate in the nitrogen redox cycles that operate in soils, water and biological fluids, affording reversible interconversions between nitrates to ammonia and vice-versa. The discovery of its biosynthesis in mammals for signaling purposes generated a research explosion on the ongoing chemistry occurring in specific cellular compartments, centered on NO reactivity toward $\mathrm{O}_{2}$, thiols, amines, and transition metals, as well as derivatives thereof. The present review deals with the coordination chemistry of $\mathrm{NO}$ toward selected iron and ruthenium centers. We place specific



The picture describes the addition of $\mathrm{OH}^{-}$into the $\mathrm{N}$-atom of bound $\mathrm{NO}^{+}$in the $\left[(\mathrm{FeCN})_{5}(\mathrm{NO})\right]^{2-}$ (nitroprusside) ion, leading to the bound intermediate $\left[(\mathrm{FeCN})_{5}\left(\mathrm{NO}_{2} \mathrm{H}\right)\right]^{3-}$. attention to the three redox states of the nitrosyl group: $\mathrm{NO}^{+}, \mathrm{NO}$ and NO-/HNO, describing changes in structure and reactivity as coordination takes place. Noteworthy are the results with the most reduced nitroxyl-species that allow establishing the changes in the measurable $\mathrm{pK}_{\mathrm{a}}$ values for the HNO-bound complexes, also revealing the abrupt decrease in reducing power and trans-releasing abilities of the protonated species over the unprotonated ones, NO- Comparative results using non-heme and heme proteins and models prove useful for suggesting further improvements in the current research status of complex enzymatic behavior.
\end{abstract}

\section{Keywords:}

nitric oxide, nitroxyl, nitrous oxide, nucleophilic/electrophilic addition, disproportionation, nitrosation, dioxygenation, hydrogen sulfide, thionitrous acid, thionitrites, perthionitrites

\section{Introduction}

Modern studies in physiology and biochemistry point to some endogenously generated small molecules, dissolved gases that are free to diffuse in solutions and permeate membranes. More than the products of metabolism, their production is regulated to fulfill messenger functions involved in signal transduction, with specific cellular and molecular targets. They have been evolutionary conserved in eukaryotes, from bacteria to plant and mammalian cells, and use to act cooperatively. Main examples are nitric oxide (NO), carbon monoxide (CO), and hydrogen sulfide $\left(\mathrm{H}_{2} \mathrm{~S}\right)$. They are frequently called "gasotransmitters", excluding the not endogenously generated dioxygen $\left(\mathrm{O}_{2}\right)$, despite that it fulfills the main described properties, among them the signaling abilities. By focusing on NO, and leaving CO aside now, we will discuss in this review the biorelevant chemistry of the latter molecules in an integrated way.[1,2]

NO, an environmental pollutant and toxin, gained prestige in the 1980s after the discovery of its biosynthesis in mammals for signaling purposes, [3] and the recognition of functions in plant biology.[4] NO is produced by a five- $\mathrm{e}^{-}$ oxidation of L-arginine with $\mathrm{O}_{2}$, catalyzed by the iron based nitric oxide synthase isozymes in the endothelium, nerves, 
and macrophages: e-NOS, n-NOS, and i-NOS, respectively. NO subsequently targets another iron enzyme, soluble guanylate cyclase (sGC), a high affinity NO-sensor that produces blood pressure control through vasodilation, as well as nerve signal transduction and immune defense. $\mathrm{NO}$ is also produced by reductive conversion from nitrite $\left(\mathrm{NO}_{2}^{-}\right)$in soils and seawater, in denitrifying bacteria and fungi, catalyzed by copper or iron heme anaerobic nitrite reductases (NIR). It is thought to be similarly produced in vivo by reaction of $\mathrm{NO}_{2}^{-}$with deoxy- $\mathrm{Hb}$ and $-\mathrm{Mb}$ for hypoxic vasodilation, a process also related with curing of meat. Other NO-binding iron heme isozymes are nitrophorins, that serve as NO carriers in the saliva of blood-sucking insects. Given its toxicity beyond the $\mu \mathrm{M}$ level, regulatory enzymatic NO production displays at 1-10 nM concentrations. Removal of NO is accomplished in mammals and in some bacteria under nitrosative stress, mainly through autoxidation forming nitrate $\left(\mathrm{NO}_{3}^{-}\right)$. A catalytic depletion of $\mathrm{NO}$ giving nitrous oxide $\left(\mathrm{N}_{2} \mathrm{O}\right)$ is afforded by heme NO-reductases (NOR) in denitrifying bacteria and fungi.[5,6]

Elucidating the biorelevant mechanistic chemistry of NO and redox derivatives is a complex task. The targets for NO-biological signaling can be the direct reactions with $\mathrm{O}_{2}$, thiols (RSH) and hydrogen sulfide $\left(\mathrm{H}_{2} \mathrm{~S}\right)$, amines, and radical species. Besides, dioxygen $\left(\mathrm{O}_{2}\right)$, superoxide $\left(\mathrm{O}_{2}^{-}\right)$, and hydrogen peroxide $\left(\mathrm{H}_{2} \mathrm{O}_{2}\right)$ have their own signaling abilities. The mutual interactions of all potential components at a given cellular microenvironment must be considered, as well as the corresponding rate constants and local concentrations of species.[1,7,8] Intermediate/products of those reactions such as nitrosothiolates (RSNO) might also produce a signaling cascade. In protein nitrosations implying modifications of a thiol group, how RSNOs are formed and how specificity is achieved for activating a given biological function are mostly unknown.[9] Most relevant to our present focus, transition metal ions can provide novel signaling features, depending on the nature of available metal-binding sites, tuning abilities exerted by coligands, second-sphere interactions with counterions or residues in vicinal protein chains, or with solvent media. Thus, the reactivity of "free" NO can be greatly modified upon coordination, as done by the multifunctional metalloenzymes necessary for the biosynthesis, transport, sensing and detoxification of NO.[6,10]

Following a brief survey on the basic solution physical and chemical properties of $\mathrm{NO} \mathrm{NO}_{\mathrm{x}}$ and redox derivatives, $[1,7]$ the coordination chemistry will be emphasized mainly by revisiting our work with a non-heme iron complex (pentacyanonitrosylferrate(II), "nitroprusside"),[11] and by using ruthenium nitrosyl models,[12] thus providing appropriate frameworks for comparison with the most biorelevant iron heme proteins. Recent aspects of the "crosstalk" of NO with $\mathrm{H}_{2} \mathrm{~S}$ will be presented, comprising the intermediacy of thionitrous acid (NOSH), nitrososulfides (thionitrites, $\mathrm{NOS}^{-}$) and nitrosodisulfides (perthionitrites, $\mathrm{NOS}_{2}^{-}$).[13] Hopefully, this account will address challenging mechanistic questions pointing to a best understanding of the role of transition metals in biological signaling. Only the main original articles related to the chemistry described will be cited, instead we provide the reader access to the most current literature, with emphasis on reviews.

\section{Properties of aqueous $\mathrm{NO}$ and redox derivatives $\mathrm{NO}^{+}, \mathrm{NO}^{-}, \mathrm{HNO}, \mathrm{NO}_{x}$}

NO is thermodynamically very unstable in water $\left(\Delta G_{\text {faq } 298 \mathrm{~K}}^{\mathrm{o}}=102 \mathrm{~kJ} / \mathrm{mol}\right)$, although it is persistent as a monomer, soluble in the $\mathrm{mM}$ range (increasing to $3-15 \mathrm{mM} / \mathrm{atm}$ in aprotic solvent), nearly non-polar, hydrophobic, diffusible, and able to freely pass the cell boundaries.[1,7] Figure 1 shows a Molecular Orbital (MO) bonding description, with the highest energy unpaired electron in an antibonding orbital, and an N-O bond order of 2.5. Remarkably, aqueous NO shows no significant tendency to dimerize, with an apparently unfavorable dimerization equilibrium constant.[14] In contrast, dimerization reactions for most inorganic radicals are very fast and effectively irreversible, except for $\mathrm{NO}_{2}, \mathrm{SO}_{2}^{-{ }^{-}}$and a few others.[14] Neither does $\mathrm{NO}$ disproportionate in water, as other oxo-nitrogenated radicals do $\left(\mathrm{NO}_{2} \cdot\right.$ and $\left.\mathrm{N}_{2} \mathrm{O}_{2}{ }^{-}\right)$, though it evolves gradually to $\mathrm{N}_{2} \mathrm{O}$ and $\mathrm{NO}_{2}$ - in pressurized $\mathrm{NO}$ gas-cylinders. The colligation reactions of $\mathrm{NO}$ with paramagnetic substrates are nearly diffusion-controlled $\left(\sim 10^{10} \mathrm{M}^{-1} \mathrm{~s}^{-1}\right)$, as with $\mathrm{NO}_{2} \cdot$ and $\mathrm{CO}_{2}^{--}$, giving $\mathrm{N}_{2} \mathrm{O}_{3}$ and $\mathrm{NOCO}_{2}^{-}$respectively.[14] Very fast reactions take place with biorelevant radicals as thiyl (RS-), peroxyl (ROO-) and tyrosyl (PhO-). Fast radical quenching by $\mathrm{NO}$ on enzyme systems serve as regulatory or inhibitory functions; many chain-carrying radicals oxidize important biological macromolecules, and a protective role for NO can be established.[1,7,14] 




$\mathrm{N}$ atomic orbitals

O atomic orbitals

Figure 1. Molecular orbital diagram for NO

A third order rate law has been verified for the aqueous autoxidation reaction (1): $\mathrm{d}\left[\mathrm{NO}_{2}^{-}\right] / \mathrm{dt}=4 k_{\mathrm{ox}}\left[\mathrm{NO}^{2}\left[\mathrm{O}_{2}\right]\right.$, with $k_{\mathrm{ox}}=2 \times 10^{6} \mathrm{M}^{-2} \mathrm{~s}^{-1}\left(25^{\circ} \mathrm{C}, \mathrm{pH}\right.$ independent). It is believed that intermediate $\mathrm{NO}_{2}$. production is rate-limiting, followed by association with $\mathrm{NO}$ giving $\mathrm{N}_{2} \mathrm{O}_{3}$, that hydrolyzes to nitrite.[7,14] Following several reports on the mechanisms, ONOONO, $\mathrm{NO}_{2}$ and $\mathrm{N}_{2} \mathrm{O}_{3}$ have been proposed as oxidizing intermediates, depending on added substrates.[15] ONOONO would be generated by the reaction of $\mathrm{NO}$ with a peroxynitrite radical formed in the initial step: ONOO (or alternatively, with a weakly bound $\mathrm{NO} \mathrm{O}_{2}$ species). No mention has been made at all on a NO-dimer as a putative endergonic precursor intermediate, subsequently reactive toward $\mathrm{O}_{2}$.

$4 \mathrm{NO}+\mathrm{O}_{2}+2 \mathrm{H}_{2} \mathrm{O} \rightarrow 4 \mathrm{H}^{+}+4 \mathrm{NO}_{2}^{-}$

Alternatively, $\mathrm{NO}_{2}$ is the final product in aprotic solvents, which raises the question on the different damaging capability of the autoxidation reaction depending on the local polarity in cells. The rate of NO-decay depends on its initial concentration: in aerated solutions and high concentrations of $\mathrm{NO}(\mu \mathrm{M}$ to $\mathrm{mM})$, the reaction takes place in seconds or less, whereas the decay is much slower at physiological concentrations $(\leq 100 \mathrm{nM})$. For example, at $1 \mathrm{mM}$ NO and 250 $\mu \mathrm{M} \mathrm{O}_{2}$, the first $\mathrm{t}_{1 / 2}$ is $0.5 \mathrm{~s}$, whereas at more physiological levels of $10 \mathrm{nM} \mathrm{NO}$ and $50 \mu \mathrm{M} \mathrm{O}_{2}$, the $\mathrm{t}_{1 / 2}$ is $\sim 50$ hours. [5,7] As $t_{1 / 2}$ decreases, the flux of reactive nitrogen species (RNS) increases, as might occur with other damaging reactive oxygen species (ROS, viz., $\mathrm{O}_{2}^{-}, \mathrm{H}_{2} \mathrm{O}_{2}$,), and requires modulation of $\mathrm{NO}$ production, accomplished by NOS isozymes on demand. Thus, NO may be involved in diverse biological functions. Most important is the very fast colligation reaction (2):

$\mathrm{NO}+\mathrm{O}_{2}^{-} \rightarrow \mathrm{OONO}^{-} \quad k_{2}=5 \times 10^{9} \mathrm{M}^{-1} \mathrm{~s}^{-1}$

A maximized production of strongly oxidizing peroxynitrite $\left(\mathrm{ONOO}^{-}\right)$can be reached upon colocalized disposal of the reactants, a process that can be inhibited by superoxide dismutase enzymes (SOD). In contrast, NO shows no reaction with $\mathrm{H}_{2} \mathrm{O}_{2}$, although the latter might be toxic by reacting with reduced metal ions ( $\mathrm{Fe}^{\mathrm{II}}, \mathrm{Cu}^{\mathrm{I}}$, leading to $\left.\mathrm{OH}\right)$, or behave as signaling agent by reacting with thiols, showing kinetic selectivity in the oxidations to sulfenic acids ( $\mathrm{RSH}+\mathrm{H}_{2} \mathrm{O}_{2} \rightarrow$ $\mathrm{RSOH}+\mathrm{H}_{2} \mathrm{O}$ ). Decomposition of $\mathrm{H}_{2} \mathrm{O}_{2}$ is regulated by catalase and peroxidase enzymes.[1,7]

Turning to the charged diatomic moieties, Figure 1 shows that $\mathrm{NO}^{+}$and $\mathrm{NO}^{-}$are accessible states upon one-electron removal or addition. Stable $\mathrm{NO}^{+}$can be isolated (viz., with $\mathrm{BF}_{4}^{-}$) and solubilized in organic solvents. Despite its bond order 3, akin to $\mathrm{CO}$ and $\mathrm{N}_{2}, \mathrm{NO}^{+}$is extremely reactive in aqueous solutions as an electrophile toward $\mathrm{OH}^{-}$, giving $\mathrm{HNO}_{2}$. On the other hand, one-electron addition to $\mathrm{NO}$ leads to the ground-state (GS) triplet ${ }^{3} \mathrm{NO}^{-}$(bond order 2, akin to $\mathrm{O}_{2}$ ) through the single occupation of each MO. A singlet excited state (ES), ${ }^{1} \mathrm{NO}^{-}$, can be reached by pairing both electrons in one of the MO's. To the relevant reduction potentials in eqs $(3,4)$, we include an estimated value to produce ${ }^{1} \mathrm{HNO}$ (nitroxyl, azanone, with a GS singlet), given by eq (5), at $\mathrm{pH}$ 7.4. We also quote the $\mathrm{pH}$-dependent conversion to $\mathrm{NO}_{2}^{-}$in reaction (6), which means that $\mathrm{NO}$ is a mild oxidant at $\mathrm{pH} 7, E=0.37 \mathrm{~V}$ (all these redox potentials are referenced to NHE).

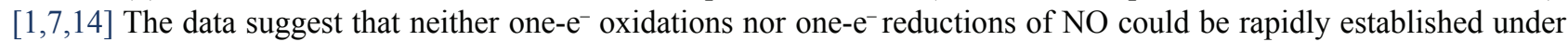
biorelevant conditions (reactions 4 and 5 are spin-forbidden); therefore, we might conclude that NO has time to diffuse from a cell to another and react accordingly (viz., with locally available highly reactive reductants such as $\mathrm{H}_{2} \mathrm{~S}$ or thiols, see below). 


$$
\begin{aligned}
& \mathrm{NO}^{+}+\mathrm{e}^{-} \rightleftarrows \mathrm{NO} \quad E_{(\mathrm{NO}+\mathrm{NO})}^{\mathrm{o}}=1.45 \mathrm{~V} \\
& \mathrm{NO}+\mathrm{e}^{-} \rightleftarrows{ }^{3} \mathrm{NO}^{-} \quad E_{\left(\mathrm{NO} / 3 \mathrm{NO}^{-}\right)}^{\mathrm{o}}=-0.81 \mathrm{~V} \\
& { }^{3} \mathrm{NO}+\mathrm{H}^{+}+\mathrm{e}^{-} \rightleftarrows{ }^{1} \mathrm{HNO} \quad E_{(\mathrm{NO}, \mathrm{H}+\mathrm{HNO})}^{\mathrm{o}}=-0.5 \mathrm{~V} \\
& \mathrm{HNO}_{2}+\mathrm{H}^{+}+\mathrm{e}^{-} \rightleftarrows \mathrm{NO}+\mathrm{H}_{2} \mathrm{O} \quad E_{(\mathrm{HNO}, \mathrm{H}+\mathrm{NO})}^{\mathrm{o}}=0.99 \mathrm{~V}
\end{aligned}
$$

There is an enormous interest on the chemical properties of aqueous $\mathrm{HNO},[16,17]$ which equilibrates with ${ }^{3} \mathrm{NO}^{-}$ through reaction (7). Reactions (8) and (9) show the different reactivity toward $\mathrm{O}_{2}$ of the protonated and deprotonated species, although $\mathrm{ONOOH}$ has been questioned as a product in reaction (8).[7] Note that the extremely fast reactions (2) and (9) are isoelectronic.

$$
\begin{array}{ll}
\mathrm{HNO}+\mathrm{OH}^{-} \rightleftarrows{ }^{3} \mathrm{NO}^{-}+\mathrm{H}_{2} \mathrm{O} & k_{7}, 4.9 \times 10^{4} \mathrm{M}^{-1} \mathrm{~s}^{-1} ; k_{-7}, 1.2 \times 10^{2} \mathrm{~s}^{-1} \\
\mathrm{HNO}+\mathrm{O}_{2} \rightarrow \mathrm{ONOOH} & k_{8}=1.8 \times 10^{4} \mathrm{M}^{-1} \mathrm{~s}^{-1} \\
{ }^{3} \mathrm{NO}^{-}+\mathrm{O}_{2} \rightarrow \mathrm{ONOO}^{-} & k_{9}=2.7 \times 10^{9} \mathrm{M}^{-1} \mathrm{~s}^{-1}
\end{array}
$$

$\mathrm{HNO}$ becomes a dominant species at $\mathrm{pH} 7$, based on the estimated value of $\mathrm{p} K_{\mathrm{a}} \sim 11.4$ for deprotonation into $\mathrm{GS}^{3} \mathrm{NO}^{-}$. $\mathrm{HNO}$ decays rapidly forming $\mathrm{N}_{2} \mathrm{O}$ through $\mathrm{pH}$-dependent pathways attributed to self-dimerization of HNO. For reaction (10), a nucleophilic addition step of ${ }^{3} \mathrm{NO}^{-}$to the $\mathrm{N}$ atom of $\mathrm{HNO}$ has been proposed, leading to cis- $\mathrm{N}_{2} \mathrm{O}_{2} \mathrm{H}^{-}$that rapidly decomposes to $\mathrm{N}_{2} \mathrm{O}$.[17]

$$
\mathrm{HNO}+{ }^{3} \mathrm{NO}^{-} \rightarrow \mathrm{N}_{2} \mathrm{O}+\mathrm{OH}^{-} \quad k_{10}=6.6 \times 10^{9} \mathrm{M}^{-1} \mathrm{~s}^{-1}
$$

We also highlight the mutual reactivity of $\mathrm{HNO} / \mathrm{NO}$ giving hyponitrite radicals, $\mathrm{N}_{2} \mathrm{O}_{2}{ }^{-}$( $\left(\mathrm{p} K_{\mathrm{a}}\right.$ of $\mathrm{HN}_{2} \mathrm{O}_{2}$, 5.6), whose chemistry has been characterized by pulse radiolysis and flash photolysis.[18] The radicals form either by one-electron oxidation of aqueous hyponitrite, $\mathrm{N}_{2} \mathrm{O}_{2}{ }^{2-}$, or by one-electron reduction of NO. In the latter case, the precursor can be either $\mathrm{HNO}$, reaction (11), or ${ }^{3} \mathrm{NO}^{-}$, which reacts much faster $\left(3 \times 10^{9} \mathrm{M}^{-1} \mathrm{~s}^{-1}\right)$. The chemistry of $\mathrm{N}_{2} \mathrm{O}_{2}^{--}$might be most biorelevant under colocalized generation of $\mathrm{NO} / \mathrm{HNO}$. In a complex process, the $\mathrm{N}_{2} \mathrm{O}_{2}{ }^{-}$radicals can disproportionate further in a rate-limiting bimolecular step, followed by fast reactions producing $\mathrm{N}_{2} \mathrm{O}$ and $\mathrm{NO}_{2}^{-}$, with $\mathrm{NO}$ and $\mathrm{N}_{3} \mathrm{O}_{3}^{-}$as catalytic intermediates.[18] We refer the reader to recent articles and reviews on the mechanistic chemistry of $\mathrm{N}_{2} \mathrm{O}$ production, most relevant to greenhouse effects, comprising the chemistry of NOR enzymes that generates $\mathrm{N}_{2} \mathrm{O}$ in soils.[19-21]

$\mathrm{HNO}+\mathrm{NO} \rightarrow \mathrm{N}_{2} \mathrm{O}_{2}^{--}+\mathrm{H}^{+} \quad k_{11}=5.8 \times 10^{6} \mathrm{M}^{-1} \mathrm{~s}^{-1}$

Finally, reaction (12) shows the reversible oxidative ability of HNO toward thiols (viz., as residues in proteins) that produces sulfenamide intermediates RSNHOH in the first step, followed by attack by a second RSH to give hydroxylamine

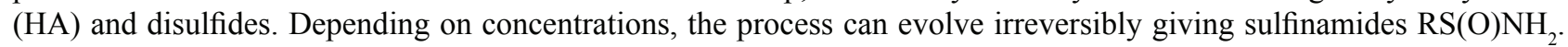
$[1,7]$

$\mathrm{HNO}+2 \mathrm{RSH} \rightleftarrows \mathrm{NH}_{2} \mathrm{OH}+\mathrm{R}_{2} \mathrm{~S}_{2} \quad k_{12}=4.5 \times 10^{6} \mathrm{M}^{-1} \mathrm{~s}^{-1}$

Endogenous synthesis of HNO is feasible though controversial.[16,17] It might occur through similar oxidative routes as for NO-production through NOS, although by a four-electron oxidation under deficient conditions of the tetrahydrobiopterin $\left(\mathrm{BH}_{4}\right)$ cofactor. Studies in vitro suggest its formation from HA or other amino alcohols, through peroxidation catalyzed by diverse hemeproteins.[17] Direct NO-reductive routes to HNO by ascorbate, tyrosine, thiols and $\mathrm{H}_{2} \mathrm{~S}$ have been reported, evolving irreversibly to $\mathrm{N}_{2} \mathrm{O}$ and oxidized species.[22,23] Though the redox potential value in reaction (5) allows questioning the accessibility of ${ }^{1} \mathrm{HNO}$ by single electron transfer, a recalculated value at $-0.12 \mathrm{~V}$ (NHE) sustains a lower barrier for PCET that might couple favorably with the fast, exergonic reactions of the intermediates.[24] Most significant is the assumed general outcome that $\mathrm{NO}$ and $\mathrm{NO}^{-} / \mathrm{HNO}$ could be easily interconverted in biological media, depending on the $\mathrm{pH}$ and redox state of the environment.

\section{Basic transition metal coordination chemistry of $\mathrm{NO}^{+}, \mathrm{NO}, \mathrm{NO}^{-}$. The Enemark- Feltham formalism and beyond}

The three redox states of the nitrosyl diatomic group can be stabilized by complexation to metal ions.[12] NO binds covalently to transition metals $\mathrm{M}$ forming diverse structural types as mononuclear, NO-bridging and cluster compounds. We focus on mononuclear species with coordination numbers (CN) 6 and 5. The Enemark and Feltham MO formalism allows describing and predicting the main geometrical and reactivity features.[25] By using the $\{\mathrm{MNO}\}^{\mathrm{n}} \operatorname{symbolism}^{\mathrm{n}}$ is 
the electron count for the metal $d$ and $\pi^{*}{ }_{\mathrm{NO}}$ orbitals), the M-N-O fragment is defined as a single entity, without assuming any electronic distribution at the M,N,O atoms. Linear M-N-O geometries are predicted for complexes with $n \leq 6$, with increasingly bent structures for $\mathrm{n}=7$ and 8 . As no role is assigned to the coligands, we must advance further by evaluating their influence on the structural, spectroscopic and reactivity properties. We must also consider the $\sigma$ and $\pi$ bonding interactions between $\mathrm{M}$ and NO. Figure 2 includes simplified diagrams of MO energy levels for $\{\mathrm{MNO}\}^{\mathrm{n}}$ systems with $\mathrm{n}=6,7,8 \cdot[26]$

(a)

$$
\begin{aligned}
& -a_{1}\left(d_{z}^{2}\right) \\
& -b_{1}\left(d_{x}^{2}-y^{2}\right) \\
& =e_{2}\left(\pi^{\star}(\mathrm{NO}), d_{x z} d_{y x}\right) \\
& =b_{2}\left(d_{x y}\right) \\
& =e_{1}\left(d_{x z} d_{y z}, \pi^{*}(\mathrm{NO})\right.
\end{aligned}
$$

(b)

$$
\begin{aligned}
& -a^{\prime}\left(d_{\mathrm{z}}{ }^{2}, \pi^{*}(\mathrm{NO})\right) \\
& -\quad d^{\prime}\left(d_{\mathrm{x}}{ }^{2}-\mathrm{y}^{2}\right) \\
& -\quad a^{\prime}\left(\pi^{*}(\mathrm{NO}), d_{\mathrm{yz}}\right. \\
& -\quad a^{\prime}\left(\pi^{*}(\mathrm{NO}), d_{\mathrm{z}}{ }^{2}\right) \\
& = \\
& =\left\{\begin{array}{l}
d_{\mathrm{xy}} \\
d_{\mathrm{xz}}, \pi^{*}(\mathrm{NO}) \\
d_{\mathrm{yz}}, \pi^{*}(\mathrm{NO})
\end{array}\right.
\end{aligned}
$$

Figure 2. Molecular orbitals in 6-coordinate $\{\mathrm{MNO}\}^{\mathrm{n}}$ complexes, with $\mathrm{M}-\mathrm{N}-\mathrm{O}$ in (a) linear situation: $\mathrm{n}=6$, and (b) bent situations: $\mathrm{n}=7,8$. From reference 26 .

We will present selected cases of nitrosyl coordination compounds with different coligand types, for the three values of n, including the total spin states $S_{\mathrm{t}}$, basic X-ray structural data, and IR spectral information on most relevant stretching frequencies, $v_{\mathrm{N}-\mathrm{O}}$ and, when available, $v_{\mathrm{Fe}-\mathrm{NO}}$. An emphasis will be placed on iron examples for non-heme and hemecoordination environments, and on some model nitrosyl ruthenium complexes. We aim at getting a comprehensive insight into the redox chemistry of the three redox states of nitrosyl, also including HNO, in well-defined coordination environments. Complementary spectroscopic results (UV-vis, EPR, NMR, Mössbauer) and DFT calculations will be considered. A more comprehensive description of biorelevant nitrosyl complexes can be found elsewhere.[10,12,26,27]

\section{3. $\{\mathrm{MNO}\}^{6}$ complexes. Close-to-Linear geometries. Dominant electrophilic reactivity: nitrosation reactions}

\subsection{Synthesis, bonding, and spectroscopies}

Table 1 shows a selection of 6C metallonitrosyl-complexes,[28-39] usually prepared by mixing NO with Fe(III) (d $\left.\mathrm{d}^{5}\right)$ precursors. Reaction (13) describes a situation for L coligands, either equatorial or axial with respect to nitrosyl, with an occasional multidentate character. We deal with the "ferri-heme" nitrosyls, which in many cases originate in high-spin labile porphyrin $\mathrm{Fe}^{\mathrm{III}}$ centers $\left(\mathrm{d}^{5}, S=5 / 2\right)$ that react fast and reversibly with $\mathrm{NO}(S=1 / 2)$, giving low-spin diamagnetic nitrosyl-products $\left(S_{\mathrm{t}}=0\right)$, with $k_{\text {on }}=\sim 10^{5} \mathrm{M}^{-1} \mathrm{~s}^{-1}$ and $k_{\text {off }}=1-50 \mathrm{~s}^{-1}$.[40,41] That moderate NO-lability has been found for $\left\{\mathrm{FeNO}^{6}{ }^{6}\right.$ complexes generated under flash-photolysis and excess $\mathrm{NO}$ conditions. On the other hand, very stable and comprehensively characterized model complexes have been recently synthesized,[33] namely the 6C [Fe(TPP)(NO) $(\mathrm{MI})]^{+}(\mathrm{MI}=1$-methylimidazole $)$ and $[\mathrm{Fe}(\mathrm{TPP})(\mathrm{NO})(\mathrm{X})]\left(\mathrm{X}=\mathrm{Cl}^{-}, \mathrm{Br}^{-}\right)$complexes, through the oxidation of corresponding $\{\mathrm{FeNO}\}^{7}$ precursors in the absence of excess NO gas; the products showed very low values of $k_{\text {off }}$ that made NO-binding essentially irreversible.[33] For stronger-field coligands like amines, cyanides, etc., the reactants may comprise lowspin aqua-complexes $\left(\mathrm{d}^{5}, S=1 / 2\right)$ that bind NO much slower and irreversibly giving also diamagnetic products, like the nitroprusside ion, best known as a sodium dihydrate salt, $\mathrm{Na}_{2}\left[\mathrm{Fe}(\mathrm{CN})_{5} \mathrm{NO}\right] \cdot 2 \mathrm{H}_{2} \mathrm{O}(\mathrm{SNP})$, with $k_{\text {on }}=0.3 \mathrm{M}^{-1} \mathrm{~s}^{-1}$. [42]

$\left[\mathrm{Fe}^{\mathrm{III}}\left(\mathrm{L}_{5}\right)\left(\mathrm{H}_{2} \mathrm{O}\right]^{\mathrm{x}}+\mathrm{NO} \rightleftarrows\left[\mathrm{M}\left(\left(\mathrm{L}_{5}\right)(\mathrm{NO})\right]^{\mathrm{x}}+\mathrm{H}_{2} \mathrm{O} \quad k_{\text {on }}, k_{\text {off }}\right.\right.$

Alternatively, $\mathrm{HNO}_{2}$ may react with $\mathrm{Fe}(\mathrm{II})\left(\mathrm{d}^{6}\right)$ precursors as in reaction (14), through binding and subsequent fast proton-assisted dehydration. High-spin ferrous aqua-complexes react much faster than the ferric ones through dissociative mechanisms; [41] corresponding low-spin complexes such as $\left.\left[\mathrm{Fe}^{\mathrm{II}}(\mathrm{CN})_{5}\right) \mathrm{H}_{2} \mathrm{O}\right]^{3-}$ react much slower $\left(k_{\text {on }(14)}, 2300 \mathrm{M}^{-1} \mathrm{~s}^{-1}\right)$. [43] Also, $\mathrm{NOBF}_{4}$ can react directly with $5 \mathrm{C} \mathrm{Fe}(\mathrm{II})$ complexes in non-aqueous media. In other methods, reduced species like arginine or hydroxylamine can be oxidized to bound $\mathrm{NO}^{+}$.

$\left[\mathrm{Fe}^{\mathrm{II}}\left(\mathrm{L}_{5}\right) \mathrm{H}_{2} \mathrm{O}\right]^{(\mathrm{x}-1)+}+\mathrm{HNO}_{2}+\mathrm{H}^{+} \rightleftarrows\left[\mathrm{M}\left(\mathrm{L}_{5}\right)(\mathrm{NO})\right]^{\mathrm{x}+}+2 \mathrm{H}_{2} \mathrm{O} \quad k_{\text {on }}, k_{\text {off }}$ 
Table 1 shows that most complexes display nearly linear M-N-O groups with $\angle \mathrm{MNO}$ lying at $170-180^{\circ}$, with high IR stretching frequencies $v_{\mathrm{N}-\mathrm{O}}$ at $1950-1900 \mathrm{~cm}^{-1}$. The reported values for $v_{\mathrm{Fe}-\mathrm{NO}}$ lie in the $650-580 \mathrm{~cm}^{-1}$ range. [6,29] Nitrosyl myoglobin (MbNO), with an axial histidine ligand, is an example among the heme NO-proteins with weak $\mathrm{N}$-imidazolic ligands, as $c d_{1}$ NIR, nitrosyl horseradish peroxidase (HRPNO) and most of the nitrophorins.[10]

Figure $2 \mathrm{~A}$ shows that the 6 electrons can fully occupy the predominantly metal orbitals $\mathrm{e}_{1}$ and $\mathrm{b}_{2}\left(\mathrm{C}_{4 \mathrm{v}}\right.$ symmetry), under sufficiently strong-field situations. Whilst $\mathrm{b}_{2}$ is essentially nonbonding, $\mathrm{e}_{1}$ is strongly $\pi$ bonding, mixing the degenerate metal $\mathrm{d}_{\mathrm{xz}}, \mathrm{d}_{\mathrm{yz}}$ with the $\pi^{*}{ }_{\mathrm{NO}}$ orbitals. In a general way, these $\pi$ "back-bonding" interactions depend on the metal $\mathrm{M}$, its charge and electronic configuration. In contrast the Fe-NO $\sigma$ interaction is very weak, as observed for poorly $\sigma$-donor diatomic species with multiple bonds. Consistent with $S_{\mathrm{t}}=0$, a limiting $\mathrm{Fe}^{\mathrm{II}} \mathrm{NO}^{+}$GS configuration corresponds with a short and linear Fe-N-O unit that maximizes the $\pi$ interaction. The latter implies a net transfer of the charge density of one electron from iron to the $\mathrm{NO}^{+}$ligand, which strengthens the $\mathrm{Fe}-\mathrm{NO}$ bond and weakens the N-O bond, thus explaining the lowering of $v_{\mathrm{N}-\mathrm{O}}$ from $2390 \mathrm{~cm}^{-1}$ in free $\mathrm{NO}^{+}$to $1950-1900 \mathrm{~cm}^{-1}$ in the bound species. In other words, some of the triplebond character of free $\mathrm{NO}^{+}$is lost upon coordination, resulting in a real distribution that must be considered intermediate between $\mathrm{Fe}^{\mathrm{II}} \mathrm{NO}^{+}$and $\mathrm{Fe}^{\mathrm{III}} \mathrm{NO}$. It must be remarked, however, that not all $\{\mathrm{FeNO}\}^{6}$ compounds are of $\mathrm{Fe}(\mathrm{II})-\mathrm{NO}{ }^{+}$type: the high-spin complex $[\mathrm{Fe}(\mathrm{TMG} 3 \text { tren })(\mathrm{NO})]^{3+}$ has been described as $\mathrm{Fe}(\mathrm{IV})-\mathrm{NO}^{-}$.[44]

Table 1 includes two porphyrin nitrosyl complexes with axial sulfur ligands having distinctive low values of $v_{\mathrm{N}-\mathrm{O}}$ at $1850 \mathrm{~cm}^{-1}$ and a pronounced bending with $\angle \mathrm{MNO}$ reaching $160^{\circ}$. Correspondingly diminished $v_{\mathrm{Fe}-\mathrm{NO}}$ values locate at 549 $530 \mathrm{~cm}^{-1}$. Whilst the first example is a model nitrosyl compound with a trans thiophenolate ligand,[35] the second one is the nitrosyl adduct of the "ferri-heme" protein, P450nor,[37] containing cysteinate as the trans ligand. In addition to $\pi$ bonding, a new type of $\sigma$-trans interaction has been described:[6] the donor sulfur-ligand forms a S-Fe $\sigma$ bond (mainly with iron $\mathrm{d}_{72}$ ), admixed with the (unoccupied) delocalized Fe-N-O $\sigma^{*}$ orbital, antibonding with respect to both the Fe$\mathrm{NO}$ and N-O bonds. Hence, partial occupation of this orbital decreases $v_{\mathrm{N}-\mathrm{O}}$ and $v_{\mathrm{Fe}-\mathrm{NO}}$ simultaneously. Other specific geometrical changes were reported for the model 6C NO-compound,[35] which we do not analyze here; we remark that it shows a nearly equal (slightly lower) value of $\mathrm{d}_{\mathrm{Fe}-\mathrm{S}}$ with respect to the NO-unbound reactant, i.e., no significant structural trans effect is onset, in contrast with the $\mathrm{n}=7$ systems that produce significant elongations in the trans $\mathrm{Fe}-\mathrm{L}$ distances upon coordination,[45] as analyzed later.

A new series of $\mathrm{n}=6[\mathrm{Fe}(\mathrm{TPP})(\mathrm{SPh})(\mathrm{NO})]$ model complexes has been synthesized containing electron-poor thiophenolates with variable donor strengths and $\mathrm{p} K_{\mathrm{a}}$ values; [36] a fine tuning of the H-bonding influence on the $\mathrm{S}$-ligands allows sensing the changes in the IR stretchings, confirming that the decrease of both $v_{\mathrm{N}-\mathrm{O}}$ and $v_{\mathrm{Fe}-\mathrm{NO}}$ correlate with the increasing binding strengths of the trans thiophenolate groups. These second-sphere H-bonding and electronic interactions appear as crucial for controlling the degree of activation of the Fe-N-O unit for P450nor catalysis during the first step of $\mathrm{N}_{2} \mathrm{O}$ production, and also determine distinctive catalytic roles for other $\mathrm{n}=6$ intermediates in cyt P450 monoxygenases, in chloroperoxidase (CPO) and NOSs, all with thiolate ligands in differently H-bonded environmental pockets.

Though not included in Table 1, previous results with other non-sulfur strong donor trans-ligands showed the same geometric changes (viz., $\mathrm{C}_{6} \mathrm{H}_{4} \mathrm{~F}, \mathrm{OH}^{-}$), $[12,45]$ suggesting that even the minor $\angle \mathrm{MNO}$ deviations from $180^{\circ}$ might be due to electronic effects rather than to steric restrictions.[34] The overall spread in $v_{\mathrm{N}-\mathrm{O}}\left(1950-1850 \mathrm{~cm}^{-1}\right)$ allows concluding that the complexes with the higher frequencies reflect a greater $\mathrm{NO}^{+}$-character. The significance of the IR results has been clarified by normal coordinate analysis calculations (NCA), which show comparatively high values for the N-O and Fe-N force constants, at $\sim 14-15$ and $4 \mathrm{mdyn} / \AA \AA$, respectively. On the other hand, the bending of the Fe-N-O units down to $160^{\circ}$ has been attributed to a different orbital origin, namely the strong $\pi$ donation by the thiolates.[6] 
Table 1. $n=6$. Selected 6-coordinated metallonitrosyl complexes, $\{\mathrm{MNO}\}^{6}(\mathrm{M}=\mathrm{Fe}, \mathrm{Ru})$, with different coligands

\begin{tabular}{|c|c|c|c|c|c|c|c|}
\hline Compound & $S_{t}$ & $\begin{array}{c}v_{\mathrm{N}-\mathrm{O}} \\
\left(\mathrm{cm}^{-1}\right)\end{array}$ & $\begin{array}{c}\mathrm{d}_{\mathrm{M}-\mathrm{NO}} \\
\left(\AA^{\circ}\right)\end{array}$ & $\begin{array}{l}\mathrm{d}_{\mathrm{N}-\mathrm{O}} \\
\left(\AA^{\circ}\right)\end{array}$ & $\begin{array}{c}\angle_{\mathrm{MNO}} \\
\left(^{\circ}\right)\end{array}$ & $\begin{array}{c}\mathrm{d}_{\text {M-Ltrans }} \\
\left(\AA^{\circ}\right)\end{array}$ & Ref \\
\hline $\mathrm{Na}_{2}\left[\mathrm{Fe}(\mathrm{CN})_{5}(\mathrm{NO})\right] \cdot 2 \mathrm{H}_{2} \mathrm{O}^{\mathrm{a}}$ & 0 & 1960 & $1.6656(7)$ & $1.133(1)$ & $176.03(7)$ & $1.9257(9)$ & 28,29 \\
\hline$[\mathrm{Fe}($ cyclam-ac $)(\mathrm{NO})] \mathrm{Cl}\left(\mathrm{ClO}_{4}\right) \cdot \mathrm{H}_{2} \mathrm{O}^{\mathrm{b}}$ & 0 & 1903 & 1.663 & 1.133 & 175.6 & 1.883 & 30 \\
\hline $\mathrm{Mb}^{\mathrm{III}} \mathrm{NO}^{\mathrm{c}}$ & 0 & 1927 & $1.68(2)$ & $1.13(1)$ & $180(4)$ & $2.04(2)$ & 31 \\
\hline$[\mathrm{Fe}(\mathrm{TPP})(\mathrm{MI})(\mathrm{NO})]^{+} \mathrm{d}$ & 0 & 1896 & $1.6275(3)$ & $1.148(5)$ & $176.3(4)$ & $1.973(3)$ & 32,33 \\
\hline$[\mathrm{Fe}(\mathrm{TPP})(\mathrm{NO})(\mathrm{Cl})]$ & 0 & 1880 & $1.668(9)$ & $1.209(8)$ & 180 & $2.099(4)$ & 33 \\
\hline$\left[\mathrm{Fe}(\mathrm{TPP})\left(\mathrm{O}_{2} \mathrm{CCF}_{3}\right)(\mathrm{NO})\right]$ & 0 & 1907 & $1.618(8)$ & $1.151(8)$ & $175.8(6)$ & $1.899(6)$ & 34 \\
\hline$\left[\mathrm{Fe}(\mathrm{OEP})\left(\mathrm{SR}-\mathrm{H}_{2}\right)(\mathrm{NO})\right]^{\mathrm{e}}$ & 0 & 1870 & $1.671(9)$ & 1.187(9) & $159.6(8)$ & $2.356(3)$ & 35,36 \\
\hline P450nor III-NO & 0 & 1851 & 1.63 & 1.16 & 161 & 2.3 & 37 \\
\hline$\left[\mathrm{Ru}\left(\mathrm{Me}_{3}[9] \mathrm{aneN}_{3}\right)(\mathrm{bpy})(\mathrm{NO})\right]\left(\mathrm{BF}_{4}\right)_{3}{ }^{\mathrm{f}}$ & 0 & 1919 & $1.761(2)$ & $1.128(3)$ & $173.2(3)$ & $2.128(4)$ & 38 \\
\hline$\left[\mathrm{Ru}\left(\mathrm{Me}_{3}[9] \mathrm{aneN}_{3}\right)(\mathrm{bpym})(\mathrm{NO})\right]\left(\mathrm{BF}_{4}\right)_{3}{ }^{\mathrm{g}}$ & 0 & 1947 & $1.776(5)$ & $1.133(7)$ & $172.5(4)$ & $2.110(6)$ & 39 \\
\hline
\end{tabular}

Abbreviations: cyclam-ac: 1,4,8,11-tetraazacyclotetradecane-1-acetate; $\mathrm{Mb}^{\mathrm{III}}$ : "ferri"-myoglobin; por: porphyne(2-); MI: 1-methylimidazole; TPP: 5,10,15,20-tetraphenylporphyrin(2-); OEP: octaethylporphyrin(2-); P450nor: Fungal cytochrome P450 NO reductase; SR- $\left.\left.\mathrm{H}_{2}: \mathrm{S}-2,6-\left(\mathrm{CF}_{3} \mathrm{CONH}\right)_{2} \mathrm{C}_{6} \mathrm{H}_{3}\right) ; \mathrm{Me}_{3}[9] \mathrm{aneN}_{3}\right): 1,4,7$-trimethyl-1,4,7triazacyclononane; bpy: 2,2'-bipyridine; bpym: 2,2'-bipyrimidine.

a) X-ray diffraction, $50 \mathrm{~K}$, ref. $28 ; v_{\mathrm{N}-0}$, ref. $29,77 \mathrm{~K}$. b) X-ray diffraction, $100 \mathrm{~K} ; v_{\mathrm{N}-\mathrm{O}}$ in $\mathrm{CD}_{3} \mathrm{CN}$. c) Geometric data from XAFS, $v_{\mathrm{N}-\mathrm{O}}$ by resonance Raman. d) $v_{\mathrm{N}-\mathrm{O}}$ corresponds to $\mathrm{BF}_{4}^{-}$salt, ref. 32. X-ray, with $\mathrm{PO}_{2} \mathrm{~F}_{2}^{-}$salt, ref. 33. Calculated geometrical data (BP86/TZVP, with a porphyne ${ }^{2-}$ ligand), see ref. 6. e) corrected value of $v_{\mathrm{N}-\mathrm{O}}$ in ref. 36 with respect to previous report in ref. 35. f) Compound $[1-\mathrm{NO}]^{3+}$, see text; $v_{\mathrm{N}-\mathrm{O}}$ in ATR mode; calculated DFT (B3LYP) are available. g) Compound $[3-\mathrm{NO}]^{3+}$, see text; data as in f).

The highest value of $v_{\mathrm{N}-\mathrm{O}}$ for nitroprusside in Table 1 is remarkable.[29] Given that cyano-ligands are strong $\sigma$-donors, one might expect a lower value, as described above for the thiolate-complexes. However, the bound cyanides also display specific H-bonds with water, $[29,46]$ which diminishes the iron electron density and consequent $\pi$-bonding ability toward nitrosyl. Upon dehydration of $\mathrm{Na}_{2}\left[\mathrm{Fe}(\mathrm{CN})_{5} \mathrm{NO}\right] .2 \mathrm{H}_{2} \mathrm{O}$ or upon dissolving the salt in acetonitrile rather than in water, $v_{\mathrm{N}-\mathrm{O}}$ decreases by $40 \mathrm{~cm}^{-1}$.[46] These examples highlight the importance of considering both the first and second coordination spheres, accounting for interactions either with the solvents, counterions, or the neighboring residues located at distal and/ or proximal positions with respect to the NO-group. Interestingly, the nitroprusside ion clearly shows a negative transinfluence of $\mathrm{NO}^{+}$, with the axial Fe-C distance becoming shorter than the equatorial ones by $0.1 \AA$ (this is also nicely reflected in the changes of $v_{\mathrm{C}-\mathrm{N}}$ ); moreover, the iron atom is displaced upwards above the equatorial plane toward the NO group.[28] More generally, the axial L becomes inert toward dissociation from iron under the electron-withdrawing influence of the $\mathrm{NO}^{+}$-group,[47] accounting for the very poor number of available 5C complexes[45] (note however a recent isolation and $\mathrm{X}$-ray characterization of $\left.5 \mathrm{C}[\mathrm{Fe}(\mathrm{TPP})(\mathrm{NO})] \mathrm{BF}_{4}\right) \cdot[33]$ Remarkably enough, the $\mathrm{p} K_{\mathrm{a}}$ for axial $\mathrm{H}_{2} \mathrm{O}$ might decrease to $\sim 3$, which means that the $\mathrm{Fe}^{\mathrm{II}} \mathrm{NO}^{+}$fragment reaches the behavior of a $\mathrm{Fe}$ (III) center.[47] Such a deprotonation of trans $-\mathrm{H}_{2} \mathrm{O}$ at $\mathrm{pH} 7$ generates significant changes in the kinetic/mechanistic parameters for the aqueous nitrosylation/denitrosylation reactions of Fe(III)-porphyrin models.[41]

UV-vis spectroscopy has been a pioneering tool for describing the electronic structure and assigning optical transitions. Early theoretical calculations with $\left[\mathrm{Fe}(\mathrm{CN})_{5}(\mathrm{NO})\right]^{2-}$ indicated a composition of the $\mathrm{HOMO}\left(\mathrm{b}_{2}\right)$ of about $85 \% \mathrm{~d}_{\mathrm{xy}}, 14 \%$ $\pi^{\mathrm{b}}{ }_{\mathrm{CN}}$, and only $1.6 \% \pi^{*}{ }_{\mathrm{CN}}$, revealing a poor $\pi$ back-donation to $\mathrm{CN}^{-} .[48]$ In contrast, the $\mathrm{e}_{1}$ MO comprised $\sim 25 \% \pi^{*}{ }_{\mathrm{NO}}$, indicating substantial Fe-NO $\pi$ back bonding. The need of an adequate modeling of the solution environment has been emphasized, as DFT calculations using continuum models appeared as inadequate because the specific H-bonds between the bound cyanides and water are not accounted for; best results were achieved by using a ZINDO approach with pointcharges located along the axis behind the cyano-ligands.[49] Good DFT results have been obtained for other Fe- and $\mathrm{Ru}$ complexes included in Table 1. Whilst the orbital compositions of the HOMOs are diverse, the LUMOs become 
predominantly $\pi_{\text {NO }}^{*}$ in all nitrosyl complexes calculated so far, with significant metal d participation. Finally, Mössbauer spectroscopy aids in describing the atomic electron densities. Small isomer shifts $(\delta)$ at $\sim 0 \mathrm{~mm} \mathrm{~s}^{-1}$ and a large quadrupole splitting $\left(\Delta E_{\mathrm{Q}}\right)$ at 1.7-2.0 $\mathrm{mm} \mathrm{s}^{-1}$ support a limiting $\mathrm{Fe}^{\mathrm{II}} \mathrm{NO}^{+}$description for a variety of iron compounds.[30]

\subsection{NO-dissociation reactions. Why is NO released so fast in the nitrosyl "ferri- hemes"?}

As shown above, the strong multiple bonds in the $\mathrm{Fe}-\mathrm{N}-\mathrm{O}$ fragment determine the thermal inertness of $\left[\mathrm{Fe}(\mathrm{CN})_{5}(\mathrm{NO})\right]^{2-}$ toward NO-dissociation, consistent with the GS dominant $\mathrm{Fe}^{\mathrm{II}} \mathrm{NO}^{+}$configuration. In striking contrast, the so-called "ferriheme" nitrosyls, also with strong bonds in the GS, display moderate values of $k_{\text {off }}$, both in model nitrosyl-porphyrins and in proteins like $\mathrm{Mb}^{\mathrm{III}} \mathrm{NO}$ or $\mathrm{Hb}^{\text {III NO}}$.[40,41] In this context, the electronic structure of $[\mathrm{Fe}(\mathrm{TPP})(\mathrm{Im})(\mathrm{NO})] \mathrm{BF}_{4}$ has been studied with nuclear resonance vibrational spectroscopy (NRVS), coupled to NCA and DFT calculations.[6,32] After confirming $\mathrm{Fe}^{\mathrm{II}} \mathrm{NO}^{+}$as the GS (with a dissociation energy of $125 \mathrm{~kJ} / \mathrm{mol}$ ), low-energy ES's have been calculated: a lowspin Fe ${ }^{\mathrm{III}} \mathrm{NO}\left(S_{\mathrm{t}}=0\right)$, slightly above the GS, has a Fe-NO dissociation energy of $42 \mathrm{~kJ} / \mathrm{mol}$, a weaker (longer) Fe-NO bond, and a lower $v_{\mathrm{Fe}-\mathrm{NO}}$. Most importantly, another higher energy $\mathrm{ES}, \mathrm{Fe} \mathrm{III}^{\mathrm{III}} \mathrm{NO}\left(S_{\mathrm{t}}=2\right)$, was found to be dissociative with respect to the Fe-NO bond. Therefore, an easy thermal access to these ES's would explain the large values of $k_{\text {off }}$ found for NO, that would constitute a general property of all the "ferri-heme" nitrosyls. The facile thermal NO-release is a crucial step in the mechanistic chemistry of the NIR enzymes, providing for a regeneration of the active aqua-sites for $\mathrm{NO}_{2}^{-}$ rebinding, and might also determine the role of the nitrophorins, favoring NO-dissociation upon injection of the saliva of the insects into the tissues of the victim for inducing vasodilation. The NOS isozymes afford such a Fe ${ }^{\text {IIIIO }}$ intermediate for supporting the catalytic NO-production and release. In brief, in all Fe $\mathrm{FI}^{\mathrm{III}}$-heme nitrosyls, $\mathrm{NO}$ forms strong Fe-NO/N-O bonds in the GS ( $\mathrm{Fe}^{\mathrm{II}} \mathrm{NO}^{+}$distribution), though it behaves as a labile ligand because of an easy thermal access to low energy ESs. Besides, as highlighted in section 3.1., mutual interactions are onset between the nitrosyl and the trans-L ligand. Thus, weaker Fe-NO bonds can be predicted for the complexes containing stronger donor trans-L's, associated with an enhanced $\mathrm{Fe}^{\mathrm{III}} \mathrm{NO}$ character.

\subsection{Electrophilic reactivity of $\mathrm{NO}^{+}$-complexes}

Bonding descriptions predict that the N-atom at the delocalized M-N-O LUMO in $\{\mathrm{MNO}\}^{6}$ complexes might be the site of attack for diverse nucleophiles (:B), with reversible adduct formation, reaction $(15):[12,27]$

$\left[\mathrm{M}\left(\mathrm{L}_{5}\right)(\mathrm{NO})\right]^{\mathrm{x}}+: \mathrm{B} \rightleftarrows\left[\mathrm{M}\left(\mathrm{L}_{5}\right)(\mathrm{N}(\mathrm{O}) \mathrm{B})\right]^{\mathrm{x}}$

Studies have been addressed with a series of group 8 metals, $\mathrm{L}$ coligands $\left(\mathrm{CN}^{-}, \mathrm{NH}_{3}, \mathrm{Cl}^{-}\right.$, polypyridines, EDTA, etc.), and different $\mathrm{B}$ nucleophiles like $\mathrm{OH}^{-}$,[50] N-binding hydrides[51] $\left(\mathrm{NH}_{3}, \mathrm{NH}_{2} \mathrm{OH}, \mathrm{N}_{2} \mathrm{H}_{4}, \mathrm{~N}_{3} \mathrm{H}\right.$, and derivatives), S-binding ones: $\mathrm{SR}^{-}, \mathrm{SH}^{-}, \mathrm{SO}_{3}{ }^{2-}$, and others. [52-55] Given the potential reductive capabilities of $\mathrm{B}$, the adducts generally decompose irreversibly through redox reactions involving oxidation of $\mathrm{B}$ and $\mathrm{NO}^{+}$-reduction.[12,27]

\subsubsection{Addition of $\mathrm{OH}^{-}$to $\{\mathrm{MNO}\}^{6}$ complexes. A linear free energy relation}

The non-redox character of $\mathrm{B}=\mathrm{OH}^{-}$describes a simplest situation from the mechanistic perspective, reaction (16): [50]

$\left[\mathrm{M}\left(\mathrm{L}_{5}\right)(\mathrm{NO})\right]^{\mathrm{n}}+2 \mathrm{OH}^{-} \rightleftarrows\left[\mathrm{M}\left(\mathrm{L}_{5}\right)\left(\mathrm{NO}_{2}\right)\right]^{(\mathrm{n}-2)}+\mathrm{H}_{2} \mathrm{O}$

All the studied metal nitrosyls show the same global stoichiometry. Second order rate-laws support a mechanism with a slow bimolecular addition step of $\mathrm{OH}^{-}$, followed by fast deprotonation of the $\left[\mathrm{ML}_{5}\left(\mathrm{NO}_{2} \mathrm{H}\right)\right]$ intermediates. Figure 3 shows a typical example for the reaction of $\left[\mathrm{Ru}(4-\mathrm{Mepy})\left(\mathrm{NH}_{3}\right)_{4}(\mathrm{NO})\right]^{3+}$ with excess $\mathrm{OH}^{-}$, forming $\left[\mathrm{Ru}(4-\mathrm{Mepy})\left(\mathrm{NH}_{3}\right)_{4}\left(\mathrm{NO}_{2}\right)\right]^{+}$. 




Figure 3. Successive spectra for the reaction of $4 \times 10^{-6} \mathrm{M}\left[\mathrm{Ru}(4-\mathrm{Mepy})\left(\mathrm{NH}_{3}\right)_{4}(\mathrm{NO})\right]^{3+}$ with $0.015 \mathrm{M} \mathrm{OH}^{-} . I=1 \mathrm{M}$ $(\mathrm{NaCl}), \mathrm{T}=35^{\circ} \mathrm{C}$. Inset: Traces of the decay of nitrosyl reactant at $240 \mathrm{~nm}$, and build-up of nitrite-product at $378 \mathrm{~nm}$. From reference 50 .

The rate constants and activation parameters have been determined, as well as values of $v_{\mathrm{N}-\mathrm{O}}$ and $E_{\mathrm{NO}+\mathrm{NO}}$ for a comprehensive set of nitrosyl-complexes (mainly Ru). The dependence of the pseudo-first order rate constants $k_{\text {obs }}$ on the concentration of $\mathrm{OH}^{-}$allowed deriving a generalized mechanistic proposal, reactions (17-19):

$$
\begin{aligned}
& {\left[\mathrm{M}\left(\mathrm{L}_{5}\right)(\mathrm{NO})\right]^{\mathrm{x}}+\mathrm{OH}^{-} \rightleftarrows\left\{\left[\mathrm{M}\left(\mathrm{L}_{5}\right)(\mathrm{NO})\right]^{\mathrm{x}}, \mathrm{OH}^{-}\right\} \quad K_{\mathrm{ip}}} \\
& \left\{\left[\mathrm{M}\left(\mathrm{L}_{5}\right)(\mathrm{NO})\right]^{\mathrm{x}}, \mathrm{OH}^{-}\right\} \rightleftarrows\left[\mathrm{M}\left(\mathrm{L}_{5}\right)\left(\mathrm{NO}_{2} \mathrm{H}\right)\right]^{\mathrm{x}-1} \quad K_{18}, k_{18}, k_{-18} \\
& \left.\left[\mathrm{M}\left(\mathrm{L}_{5}\right)\left(\mathrm{NO}_{2} \mathrm{H}\right)\right]^{\mathrm{x}-1}+\mathrm{OH}^{-} \rightleftarrows \mathrm{M}\left(\mathrm{L}_{5}\right)\left(\mathrm{NO}_{2}\right)\right]^{\mathrm{x}-2}+\mathrm{H}_{2} \mathrm{O} \quad K_{19}
\end{aligned}
$$

Reaction (17) comprises a fast association preequilibrium, prior to the relevant unimolecular nucleophilic addition step (18) that forms the $\mathrm{HNO}_{2}$ adduct-intermediate. The latter may go back to the reactants or deprotonate rapidly as in eq (19) to form the final $\mathrm{NO}_{2}^{-}$-product, which is generally most stable toward nitrite-dissociation. The addition rate constants $k_{\mathrm{OH}}$ can be obtained by fitting the plots of $k_{\mathrm{obs}}\left(\mathrm{s}^{-1}\right)$ against $\left[\mathrm{OH}^{-}\right]$, which behave linearly at moderate-to-high concentrations of $\mathrm{OH}^{-}$, though reaching a $\mathrm{pH}$-independent behavior at low pH's. Figure 4 shows how $\ln k_{4}$ [50] (which corresponds to $\ln$ $k_{18}$ in our mechanistic scheme), depends linearly on the redox-potential $E_{\mathrm{NO}+\mathrm{NO}}$, with a slope of $\sim 20 \mathrm{~V}^{-1}$; some members of the trans- $\left[\mathrm{Ru}(\mathrm{py})_{4}(\mathrm{~L})(\mathrm{NO})\right]^{\mathrm{x}+}$ (in the parallel line) show lower rates than expected, probably because of steric hindrance for the $\mathrm{OH}^{-}$-access. For reaction (18), $k_{18}\left(\mathrm{~s}^{-1}\right)$ correlates with other nucleophilicity indicators such as the calculated charge at the MNO moieties.[50] Note that $k_{18}\left(\mathrm{~s}^{-1}\right)$ can be estimated according to: $k_{\mathrm{OH}}=K_{\mathrm{ip}} \times k_{18}$, by using calculated values for $K_{\text {ip }}$ that depend on the charges of the reacting complexes. The experimental $k_{\mathrm{OH}}$ values $\left(\mathrm{M}^{-1} \mathrm{~s}^{-1}\right)$ reflect the trends in the values of $k_{18}$, with a minor influence of $K_{\mathrm{ip}}$. [56] Following the work in ref. 50, new complexes have been measured (viz., $\left.[\mathrm{Ru}(\mathrm{bpy})(\mathrm{tpm})(\mathrm{NO})]^{3+},[\mathrm{Ru}(\mathrm{EDTA})(\mathrm{NO})]\right)$, and the results have been included in subsequent reviews, [11,27,51] with very minor deviations in the corresponding slopes. 


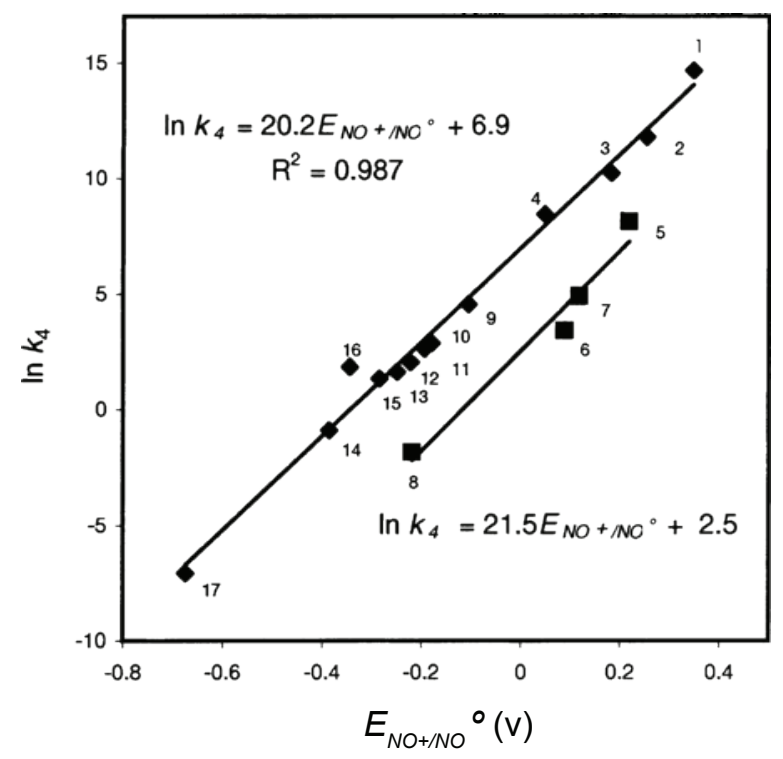

Figure 4. LFER plot of $\ln k_{4}$ (corresponds to $\ln k_{18}$, see text) against $E_{\mathrm{NO}+\mathrm{NO}}(v s \mathrm{Ag} / \mathrm{AgCl} 3 \mathrm{M} ; 0.21 \mathrm{~V} v s \mathrm{NHE})$ for the reactions of several nitrosyl-complexes with $\mathrm{OH}^{-}$: 1. cis- $\left[\mathrm{Ru}(\mathrm{AcNO})(\mathrm{bpy})_{2}(\mathrm{NO})\right]^{3+} ; 2$. cis- $[\mathrm{Ru}(\mathrm{bpy})(\operatorname{trpy})(\mathrm{NO})]^{3+}$;

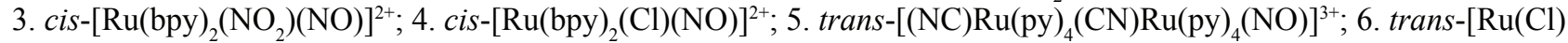

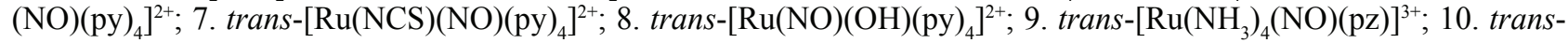
$\left[\mathrm{Ru}\left(\mathrm{NH}_{3}\right)_{4}(\text { nic })(\mathrm{NO})\right]^{3+} ; 11$. trans- $\left[\mathrm{Ru}(\mathrm{Clpy})\left(\mathrm{NH}_{3}\right)_{4}(\mathrm{NO})\right]^{3+} ; 12$. trans- $\left[\mathrm{Ru}\left(\mathrm{NH}_{3}\right)_{4}(\mathrm{NO})(\mathrm{py})\right]^{3+} ; 13$. trans- $[\mathrm{Ru}(4-\mathrm{Mepy})$ $\left.\left(\mathrm{NH}_{3}\right)_{4}(\mathrm{NO})\right]^{3+} ; 14$. trans $-\left[\mathrm{Ru}(\mathrm{his})\left(\mathrm{NH}_{3}\right)_{4}(\mathrm{NO})\right]^{3+} ; 15 .\left[\mathrm{Fe}(\mathrm{CN})_{5}(\mathrm{NO})\right]^{2-} ; 16 .\left[\mathrm{Ru}(\mathrm{CN})_{5}(\mathrm{NO})\right]^{2-} ; 17 .\left[\mathrm{Os}(\mathrm{CN})_{5}(\mathrm{NO})\right]^{2-}$. From reference 50 .

Figure 4 describes a linear free-energy relationship (LFER), as found in the trends of kinetic vs thermodynamic parameters for reactions governed by the same mechanism. Remarkably, the correlation spans $\sim 10$ orders of magnitude in the values of $k_{4}$, covering around $1 \mathrm{~V}$ in the redox potentials. The value of the slope is close to that predicted for LFER's in weakly coupled outer-sphere, one-electron transfer reactions $\left(19.4 \mathrm{~V}^{-1}\right.$ or $\left.0.5 / \mathrm{RT}\right)$, under a Marcus' treatment for cross reactions that can be extended to associative mechanistic situations. The increase in rate constants and redox potentials correlates with an increase in both the activation enthalpies and entropies. While the trends in the entropies relate to the changes in solvation, the increase in the enthalpic barriers accounts for the reorganization of the linear M-N-O moieties to angular $\mathrm{M}-\mathrm{NO}_{2} \mathrm{H}$ ones.[50]

As part of the DFT analysis, Figure 5 describes the optimized geometries for the initial steps of the $\mathrm{OH}^{-}$-addition into nitroprusside. Figure 6 shows the corresponding geometries for other selected ruthenium nitrosyl-complexes. A detailed account of computational methodologies, results, and interpretations for additions in the series of $\left[\mathrm{ML}_{5} \mathrm{NO}^{\mathrm{x}}\right.$ complexes can be found elsewhere. $[27,50,56]$

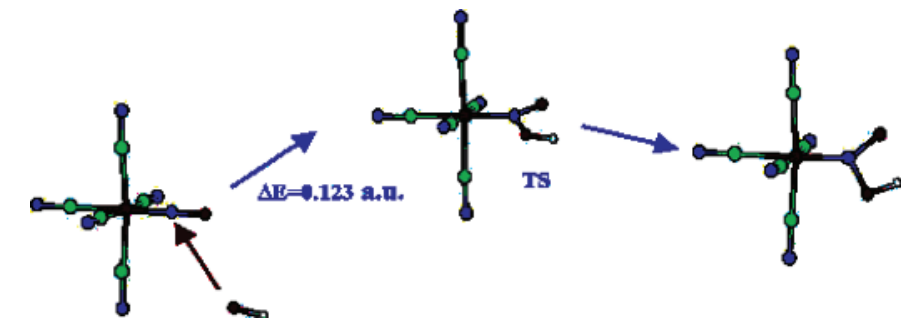

Figure 5. Optimized geometries for the initial steps of the reaction of $\left[\mathrm{Fe}(\mathrm{CN})_{5}(\mathrm{NO})\right]^{2-}$ with $\mathrm{OH}^{-}$leading to the transition state and the $\left[\mathrm{Fe}(\mathrm{CN})_{5}\left(\mathrm{NO}_{2} \mathrm{H}\right)\right]^{3-}$ intermediate. Relative energies (y-coordinate) are not drawn to scale. From reference 50. 


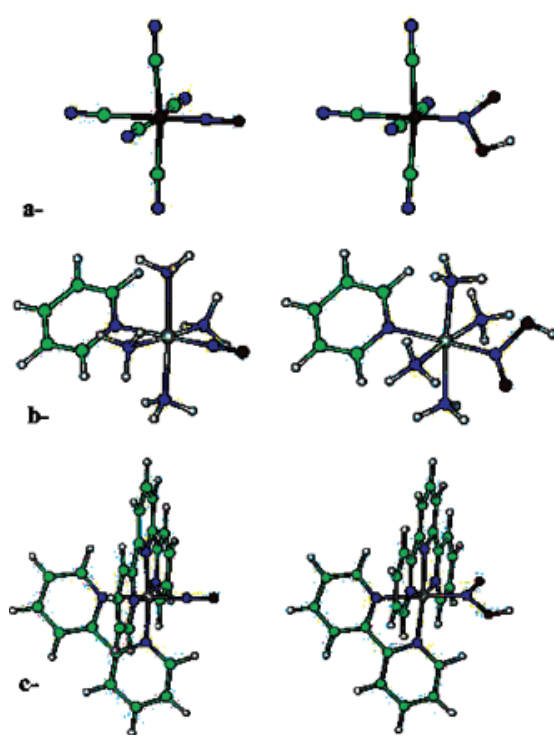

Figure 6. Optimized geometries at the $\mathrm{B} 3 \mathrm{LYP} / 6-31 \mathrm{G}^{* *}$ level for representative reactants and $\mathrm{OH}^{-}$addition intermediates:

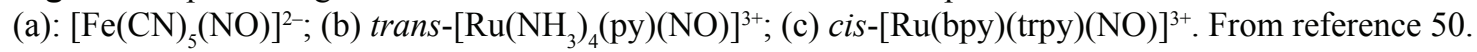

The $\mathrm{OH}^{--}$-additions have not been directly studied for the reactions of heme-nitrosyl proteins and models; [40,41] instead, the $\mathrm{Fe}-\mathrm{NO}_{2} \mathrm{H}$ intermediates, assumed to be transiently formed during the reactions of $\mathrm{Fe}(\mathrm{III})$-hemes with an excess of $\mathrm{NO}$ (eq 13), led to [ $\mathrm{Fe}^{\mathrm{II}}\left(\right.$ por)(NO)] $+\mathrm{HNO}_{2}$ as final products, in a so-called "reductive-nitrosylation" process (i.e., no bound-nitrite products were generated, in contrast with the non-hemes).[41] By using data for the measured decay of [ $\mathrm{Fe}($ por $\left.)\left(\mathrm{H}_{2} \mathrm{O}\right)(\mathrm{NO})\right]^{+}$at different $\mathrm{pHs}$, we made an estimation of values for $k_{\mathrm{OH}} \sim 10^{3} \mathrm{M}^{-1} \mathrm{~s}^{-1}$ for $\mathrm{Hb}^{\mathrm{II}} \mathrm{NO}$ and $\mathrm{Mb}^{\mathrm{II}} \mathrm{NO}$ (from the linear plots of the rate constants $v s\left[\mathrm{OH}^{-}\right]$).[56] The results for the hemeproteins compare qualitatively well with those from the classical complexes located at the upper right part of Fig. 4. We extended this analysis to other $\mathrm{Fe}^{\text {III- }}$ models with substituted-porphyrins bearing different charges: porf $^{8-}$, TPPS $^{4-}$, $(\mathrm{TMPyP})^{4+}$ and porf $^{8+}$. $[41,56]$ The values of $k_{\mathrm{OH}}$ were in the range $10^{3}-10^{8} \mathrm{M}^{-1} \mathrm{~s}^{-1}$, increasing in the previous order, as predicted by the onset of rate-determining nucleophilic addition steps (eq18), determined by the increased electrophilicities at the $\{\mathrm{MNO}\}$ moieties, induced by the electron-attractive abilities of the more positively charged substituents at the porphyrin cores. The latter results and interpretations preclude a more detailed quantitative analysis, owing to the complex porphyrin moieties (with many factors influencing the kinetic parameters), [41] and the perturbations that arise when using excess NO for the onset of the initial equilibrium reaction (13).[33] A better scenario could arise by using the pure isolated $n=7$ nitrosyl-complexes as direct precursors for the oxidized porphyrin $\mathrm{Fe}^{\mathrm{II}} \mathrm{NO}^{+}$reactants that subsequently would react with $\mathrm{OH}^{-}$.[33]

\subsubsection{Additions of $\mathrm{N}$-hydrides to nitroprusside. Linkage isomers and $\mathrm{N}_{2} \mathrm{O} / \mathrm{N}_{2}$ release}

Small nitrogenated hydrides are active nucleophiles in aqueous media toward bound $\mathrm{NO}^{+}$, according to the following stoichiometries:[51]

$$
\begin{aligned}
& {\left[\mathrm{Fe}(\mathrm{CN})_{5}(\mathrm{NO})\right]^{2-}+\mathrm{NH}_{3}+\mathrm{OH}^{-} \rightarrow\left[\mathrm{Fe}(\mathrm{CN})_{5}\left(\mathrm{H}_{2} \mathrm{O}\right)\right]^{3-}+\mathrm{N}_{2}+\mathrm{H}_{2} \mathrm{O}} \\
& {\left[\mathrm{Fe}(\mathrm{CN})_{5}(\mathrm{NO})\right]^{2-}+\mathrm{NH}_{2} \mathrm{R}+\mathrm{OH}^{-} \rightarrow\left[\mathrm{Fe}(\mathrm{CN})_{5}\left(\mathrm{H}_{2} \mathrm{O}\right)\right]^{3-}+\mathrm{N}_{2}+\mathrm{ROH}} \\
& {\left[\mathrm{Fe}(\mathrm{CN})_{5}(\mathrm{NO})\right]^{2-}+\mathrm{NH}_{2} \mathrm{OH}+\mathrm{OH}^{-} \rightarrow\left[\mathrm{Fe}(\mathrm{CN})_{5}\left(\mathrm{H}_{2} \mathrm{O}\right)\right]^{3-}+\mathrm{N}_{2} \mathrm{O}+\mathrm{H}_{2} \mathrm{O}} \\
& {\left[\mathrm{Fe}(\mathrm{CN})_{5}(\mathrm{NO})\right]^{2-}+\mathrm{N}_{3} \mathrm{H}+\mathrm{OH}^{-} \rightarrow\left[\mathrm{Fe}(\mathrm{CN})_{5}\left(\mathrm{H}_{2} \mathrm{O}\right)\right]^{3-}+\mathrm{N}_{2}+\mathrm{N}_{2} \mathrm{O}} \\
& {\left[\mathrm{Fe}(\mathrm{CN})_{5}(\mathrm{NO})\right]^{2-}+\mathrm{N}_{2} \mathrm{H}_{4}+\mathrm{OH}^{-} \rightarrow\left[\mathrm{Fe}(\mathrm{CN})_{5}\left(\mathrm{H}_{2} \mathrm{O}\right)\right]^{3-}+\mathrm{N}_{2} \mathrm{O}+\mathrm{NH}_{3}}
\end{aligned}
$$

Reactions (20-24) comprise additions on the $\mathrm{N}$ atom of the M-N-O fragment, coupled with deprotonation, as evidenced by $\mathrm{pH}$-dependent rate laws with a first order behavior in complex- and nucleophile-concentrations. All the adducts reorganize with subsequent generation of gaseous products, $\mathrm{N}_{2}$ and/or $\mathrm{N}_{2} \mathrm{O}$, and a final production of labile $\left[\mathrm{Fe}(\mathrm{CN})_{5}\left(\mathrm{H}_{2} \mathrm{O}\right)\right]^{3-}$, that can be trapped by scavenger ligands such as pyridines or pyrazines. Remarkably, if the reactions with primary/secondary amines or amino acids are carried out in nonaqueous solvents, different stoichiometries and mechanisms lead to variable organic products, depending on the amine.[57-59] Scheme 1 describes the reaction pathways 
for the aliphatic amines, with the intermediacy of stabilized diazonium species that yield mainly the corresponding diamines.[60]<smiles>[3H][N+](C)(C)[N+](C)(C)C</smiles><smiles>CC(C)[C@@H](C)N</smiles>

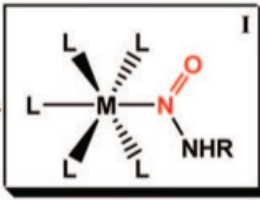

NITROSAMINE<smiles>C=CC</smiles>

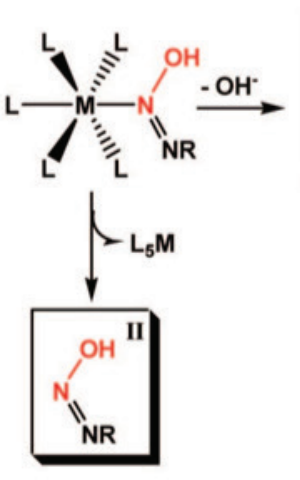

DIAZOIC ACID

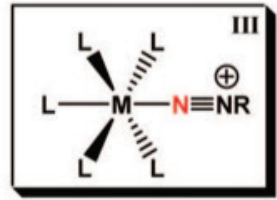

DIAZONIUM

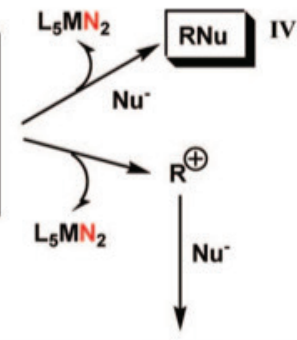

$\mathrm{RNu}+\mathrm{R}^{\prime} \mathrm{Nu}$ + alkenes

$\mathbf{R}^{\prime}$ = rearranged $\mathbf{R}$

\section{Scheme 1}

In contrast with the H-bonds established by the bound cyanides with water, weaker acceptor aprotic solvents make the iron center more electron-rich, leading to an increased back-bonding to the nitrosyl group,[46] that aids stabilizing the diazonium ligand. As a result, changes in the nitrosating ability of nitroprusside in lipophilic media might be predicted as compared to water.[60]

Figure 7 describes the theoretical (DFT) description of the $\mathrm{N}_{2} \mathrm{H}_{4}$-intermediates in reaction (24), and Scheme 2 describes the proposed steps for the overall process, with subsequent deprotonation and $\mathrm{N}-\mathrm{N}$ cleavage, leading to $\mathrm{NH}_{3}$ and to the side-on $\eta^{2}-\mathrm{N}_{2} \mathrm{O}$ and end-on $\eta^{1}-\mathrm{N}_{2} \mathrm{O}$ isomers.[61]

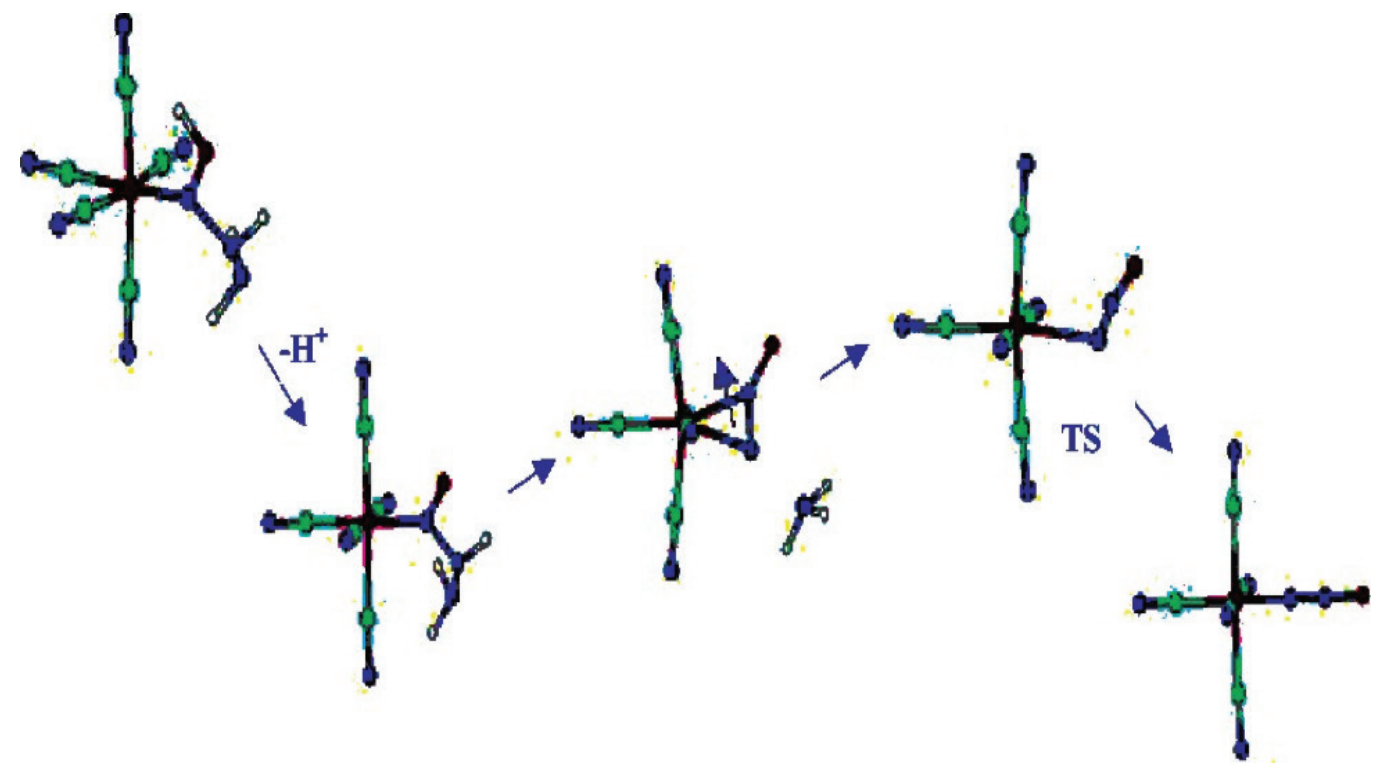

Figure 7. Schematic representation of the calculated stable intermediates for the reaction of $\left[\mathrm{Fe}(\mathrm{CN})_{5}(\mathrm{NO})\right]^{2-}$ with hydrazine rendering the $\mathrm{N}_{2} \mathrm{O}$-bound species. The structures correspond to singular points in the potential hypersurface, calculated at a B3LYP-6-31G** level. Relative energies (y-coordinate) are not drawn to scale. All adducts and intermediates, except for the first one, bear charge $3^{-}$. From reference 61. 




Scheme 2

The final products $\mathrm{N}_{2} \mathrm{O}$ and $\left[\mathrm{Fe}(\mathrm{CN})_{5}\left(\mathrm{H}_{2} \mathrm{O}\right)\right]^{3-}$ allow further coordination of $\mathrm{NO}^{+}$coming from nitrite. Studies using labeled nitroprusside $\left({ }^{15} \mathrm{NO}\right)$ led to a quantitative identification of the gaseous product ${ }^{14} \mathrm{~N}^{15} \mathrm{NO}$, with no label at $\mathrm{NH}_{3}$. This fact, together with DFT evidence, supports the proposed catalytic reduction of $\mathrm{NO}_{2}^{-}$by $\mathrm{N}_{2} \mathrm{H}_{4}$ occurring in appropriate conditions. Interestingly, the addition of $\mathrm{N}_{2} \mathrm{H}_{4}$ to other nitrosyl complexes led to azide-formation, not to $\mathrm{N}_{2} \mathrm{O}$. The prediction of the $\mathrm{N}_{2} \mathrm{O}$-linkage isomers reminds the results on the NO-analogs described elsewhere.[27-29] Direct spectroscopic evidence exists only for the coordination of $\eta^{1}-\mathrm{N}_{2} \mathrm{O}$ on some Ru- and Os-complexes. The involvement of $\eta^{2}-\mathrm{N}_{2} \mathrm{O}$ and $\eta^{1}-\mathrm{N}_{2} \mathrm{O}$ in reaction (24) is supported by the consistent geometrical and IR parameters derived from the DFT treatment,[61] a general feature for all the hydrides.[51] A similar approach proved useful to describe the side-on and end-on $\mathrm{N}_{2}$-linkage isomers.[51]

In the $\mathrm{N}_{2} \mathrm{O}$-forming reactions of Me-substituted derivatives of $\mathrm{N}_{2} \mathrm{H}_{4}$ adding to nitroprusside, closely related stoichiometries and mechanisms have been found for methylhydrazine and 1,1-dimethylhydrazine, forming methylamine and dimethylamine as products, respectively. The rates decrease by a factor of 10 for each Me-substitution, supporting an attack through the $\mathrm{NH}_{2}$ groups. Remarkably, the reaction with 1,2-dimethylhydrazine follows a route with a very different stoichiometry. It comprises a full six-electron reduction of $\mathrm{NO}^{+}$to $\mathrm{NH}_{3}$, with formation of azomethane, reaction (25). The mechanism involves the production of two-electron reduced intermediates, $\left[\mathrm{Fe}(\mathrm{CN})_{5}(\mathrm{HNO})\right]^{3-}$ and $\left[\mathrm{Fe}(\mathrm{CN})_{5}\left(\mathrm{NH}_{2} \mathrm{OH}\right)\right]^{3-}$. [61]

$\left.\mathrm{IFe}(\mathrm{CN})_{5}(\mathrm{NO})\right]^{2-}+3 \mathrm{MeHNNHMe} \rightarrow\left[\mathrm{Fe}(\mathrm{CN})_{5}\left(\mathrm{NH}_{3}\right)\right]^{3-}+\mathrm{H}_{3} \mathrm{O}^{+}+3 \mathrm{MeNNMe}$

The attack of N-binding nucleophiles to bound $\mathrm{NO}^{+}$is at the heart of the mechanisms of $\mathrm{NO}_{2}^{-}$-reductions in soils by bacteria and reducing enzymes, evolving to gaseous products, $\mathrm{N}_{2} / \mathrm{N}_{2} \mathrm{O}$. The binding of $\mathrm{NO}_{2}^{-}$into an $\mathrm{Fe}^{\mathrm{II}}$ center giving bound- $\mathrm{NO}^{+}$(cf. reaction 14) is considered the first step toward further reactivity of the nitrite reductase (NIR) enzymes. Overall, the fascinating diversity of stoichiometries and mechanisms observed by exerting subtle variations in the structure of $\mathrm{N}_{2} \mathrm{H}_{4}$ and substituted derivatives adding to the electrophilic Fe-N-O center calls attention to the complexities found in Nature for the action of different NIRs, as seen by looking at the recently proposed detailed mechanism for the sixelectron reductions on the heme-based cytochrome $c$ NIR enzyme, controlled by the concerted H-bonding interactions of different adjacent amino acids to the active centers along each of the one-electron reduction processes down to $\mathrm{NH}_{3}$.[62]

Finally, the described addition-chemistry of $\mathrm{NH}_{2} \mathrm{OH}(\mathrm{HA})$ allows highlighting the biorelevance of this endogenously generated molecule, closely related to the oxidative chemistry of arginine, hydroxyurea, etc.[17] The catalytic disproportionation of $\mathrm{NH}_{2} \mathrm{OH}$ is aided by coordination into $\left[\mathrm{Fe}(\mathrm{CN})_{5}\left(\mathrm{H}_{2} \mathrm{O}\right)\right]^{3-},[63]$ and $\mathrm{Fe}^{\mathrm{IIII}}$-porphyrinate compounds,[64] and studies have been extended to substituted $N$-alkylhydroxylamines: $\left.\mathrm{CH}_{3} \mathrm{~N}(\mathrm{H}) \mathrm{OH},\left(\mathrm{CH}_{3}\right)_{2} \mathrm{NOH}\right),[65]$ and $O$-methylhydroxylamine.[66] Biochemically significant mechanistic differences (comprising $\mathrm{Fe}^{\mathrm{IIIIII}}$ cycling and formation of different radical intermediates) reflect in the production of $\mathrm{NH}_{3}$ and diverse oxidation products when using either $\mathrm{HA}$ $\left(\mathrm{N}_{2}, \mathrm{HNO}, \mathrm{N}_{2} \mathrm{O}\right.$, and $\left.\mathrm{NO}^{+}\right)$or the substituted derivatives.

\subsubsection{Addition of thiolates (RS') and HS-. The "Gmelin" reaction}

Adducts of nitroprusside with aliphatic thiols RSH (including cysteine and glutathione) form faster than with $\mathrm{OH}^{-}$or amines, and lead to $\mathrm{pH}$-dependent second-order rate constants for the formation of bound nitrosothiolates, $\left[\mathrm{Fe}(\mathrm{CN})_{5}(\mathrm{NOSR})\right]^{3}$. $[52,53]$ Red colors develop up to the completion of the reversible reaction (26), at pHs 9-10, though plunging the adducts 
into buffers at $\mathrm{pH}$ 4-6 effected its dissociation. Subsequent slower color fading due to redox decomposition of the nitrosothiolate fragment leads to reaction (27):

$$
\begin{aligned}
& {\left[\mathrm{Fe}(\mathrm{CN})_{5}(\mathrm{NO})\right]^{2-}+\mathrm{RS}^{-} \rightleftarrows\left[\mathrm{Fe}(\mathrm{CN})_{5}(\mathrm{NOSR})\right]^{3-} k_{\mathrm{f}}, k_{\mathrm{d}}} \\
& {\left[\mathrm{Fe}(\mathrm{CN})_{5}(\mathrm{NOSR})\right]^{3-} \rightarrow\left[\mathrm{Fe}(\mathrm{CN})_{5}(\mathrm{NO})\right]^{3-}+0.5 \mathrm{R}_{2} \mathrm{~S}_{2}}
\end{aligned}
$$

From the $\mathrm{pH}$-dependence of $k_{\mathrm{f}}$, only $\mathrm{RS}^{-}$showed to be reactive, not RSH.[53] The values of $k_{\mathrm{f}}\left(3 \times 10^{3}-4 \times 10^{4} \mathrm{M}^{-1} \mathrm{~s}^{-1}\right.$, $\left.25^{\circ} \mathrm{C}\right)$ vary little for all studied thiols, with similar values of $\Delta H^{\ddagger}(\sim 33 \mathrm{~kJ} / \mathrm{mol})$. Negative activation entropies $(\sim-50 \mathrm{~J} / \mathrm{K}$ mol) agree with the association of like charges. There is a much larger variation in the values of $k_{\mathrm{d}}\left(12\right.$ to $\left.3 \times 10^{3} \mathrm{~s}^{-1}\right)$. The influence on the kinetic parameters of protonation, charge, steric effects, and solvation features of different groups in the thiols was reported.[53] Interesting mechanistic changes as compared to $\left[\mathrm{Fe}(\mathrm{CN})_{5}(\mathrm{NO})\right]^{2}$ were found for cysteine reacting with $\left[\mathrm{Ru}(\mathrm{CN})_{5}(\mathrm{NO})\right]^{2-}$ and other positively charged Ru-nitrosyls, showing a two-step addition process that led to the production of $\mathrm{N}_{2} \mathrm{O}$.[54] Remarkably, similar LFER relations as found with $\mathrm{OH}^{-}$additions were also obtained for the much faster $\mathrm{RS}^{-}$additions to a wide set of electrophilic Ru-nitrosyl-complexes.[54] Overall, the latter results showed large stoichiometric and kinetic/mechanistic variations related to the different nucleophilic abilities of $\mathrm{SR}^{-}$and $\mathrm{OH}^{-}$, as well as to the controlled changes of redox potentials of the electrophilic nitrosyl-complexes through an adequate design. The latter properties might be useful for better understanding how functional specificity is attained for thiolate nucleophiles in protein nitrosation processes, through the fine tuning of their reactivities under the influence of nearby electrostatic fields or the interactions with vicinal charged residues.

The putatively similar "Gmelin" reaction $\left(\left[\mathrm{Fe}(\mathrm{CN})_{5}(\mathrm{NO})\right]^{2-}\right.$ with $\left.\mathrm{H}_{2} \mathrm{~S}\right)$ has been studied for a long time.[55] There is a renewed interest in disclosing how HS ${ }^{-}$behaves mechanistically in a different way as RS'. For "Gmelin", HS' behaves as a poorer nucleophile $\left(k_{\mathrm{f}}, 190 \mathrm{M}^{-1} \mathrm{~s}^{-1}\right)$, and the stoichiometry leads to $\mathrm{N}_{2} \mathrm{O}, \mathrm{S}_{8}$, and Prussian-blue type species. [55] The reported mechanism was questioned and a new proposal has been raised.[67] There are still unsolved issues on the identity of the $\mathrm{pH}$-dependent emerging intermediates, probably bound thionitrous acid $\{(\mathrm{H}) \mathrm{SNO})\}$, thionitrite $\mathrm{NOS}^{-}$, perthionitrite $\mathrm{NOS}_{2}^{-}$, and HNO.[68,72] Such N/S intermediates have been known for a long time, though their biorelevance is of much recent interest.[69] They can be generated as free species following transnitrosation reactions like (28) and (29) and provide an input to the emerging studies on the chemistry of sulfides and disulfides as biologically relevant signaling species.

$$
\begin{aligned}
& \left.\mathrm{RSNO}+\mathrm{HS}^{-}+\mathrm{H}^{+} \rightleftarrows\{(\mathrm{H}) \mathrm{SNO})\right\}+\mathrm{RSH} \\
& \{(\mathrm{H}) \mathrm{SNO})\}+\mathrm{HS}_{2}{ }^{-} \rightleftarrows \mathrm{NOS}_{2}{ }^{-}+\mathrm{HS}^{-}+\mathrm{H}^{+}
\end{aligned}
$$

The highly controversial issues around the chemistry and physiological relevance of the $\mathrm{NO} / \mathrm{H}_{2} \mathrm{~S}$ "crosstalk" reactions have been recently considered, $[13,71,72]$ and contribute to display a promising scenario for best interpreting the complex coordination chemistry involved in the "Gmelin" process, which most probably includes the onset of the three redox states of the bound nitrosyl ligand, as well as corresponding redox steps for the sulfur species (HS ${ }^{-}, \mathrm{HS}^{-}, \mathrm{S}^{\circ}$ ) as crucial intermediates, thus highlighting the specific role of disulfides and polysulfides when $\mathrm{H}_{2} \mathrm{~S}$ is used as a nucleophile in place of thiols.

\section{4. $\{\mathrm{MNO}\}^{7}$ complexes. Partially bent $6 \mathrm{C}$ and $5 \mathrm{C}$ geometries. A diverse picture of electronic structures and nucleophilic reactivities}

\subsection{Synthesis, bonding, and spectroscopies}

Direct mixing of $\mathrm{NO}$ with labile $\mathrm{d}^{6} \mathrm{Fe}(\mathrm{II})$-aqua complexes forms stable $\{\mathrm{MNO}\}^{7}$ species, reaction (30). The products can be also obtained from the $\mathrm{n}=6$ or $\mathrm{n}=8$ precursors, by chemical/electrochemical means.

$\left[\mathrm{Fe}^{\mathrm{II}}\left(\mathrm{L}_{5}\right)\left(\mathrm{H}_{2} \mathrm{O}\right)\right]^{\mathrm{x}}+\mathrm{NO} \rightleftarrows\left[\mathrm{M}\left(\mathrm{L}_{5}\right)(\mathrm{NO})\right]^{\mathrm{x}}+\mathrm{H}_{2} \mathrm{O} \quad k_{\text {on }}, k_{\text {off }}$

The Enemark and Feltham formalism leaves room for large variations of the electronic structure mediated by metal-ligand covalency, leading all the way from $\mathrm{Fe}^{\mathrm{III}} \mathrm{NO}^{-}$to $\mathrm{Fe}^{\mathrm{II}} \mathrm{NO}$ and $\mathrm{Fe}^{\mathrm{I}} \mathrm{NO}^{+}$limiting electronic distributions. $[6,73]$ Complexes with ground states $S_{\mathrm{t}}=3 / 2$ or $S_{\mathrm{t}}=1 / 2$ have been identified. Figure 1B allows for high-spin or low-spin distributions, according to ligand field strengths. Non heme complexes like $[\mathrm{Fe}(\mathrm{EDTA})(\mathrm{NO})]$ and $\left[\mathrm{Fe}\left(\mathrm{H}_{2} \mathrm{O}\right)_{5}(\mathrm{NO})\right]^{2+}$ react with NO forming $S_{t}=3 / 2$ products, as also done by some Fe metalloproteins.[41,74] X-ray, Resonance Raman, XAFS, MCD and Mössbauer spectroscopies, and theoretical calculations, support an electronic description of nitrosyl products as $\mathrm{Fe}^{\mathrm{III}} \mathrm{NO}^{-}$, comprising antiferromagnetic coupling between high-spin ferric $(S=5 / 2)$ and ${ }^{3} \mathrm{NO}^{-}(S=1)$. For the $S_{\mathrm{t}}=$ 
$3 / 2\left[\mathrm{Fe}\left(\mathrm{L}_{5}\right)(\mathrm{NO})\right]^{\mathrm{x}}$ complexes in reaction (30), values of $k_{\text {on }}$ are $10^{6}-10^{8} \mathrm{M}^{-1} \mathrm{~s}^{-1}$, whereas $k_{\text {off }}$ varies around $10^{-1}-10^{3} \mathrm{~s}^{-1}$, depending on L. Water exchange measurements and activation parameters support dissociative-interchange mechanisms for these highly labile systems, which behave as potential catalysts for NO removal from gas streams.[41] Though the nitrosyl complexes with high-spin iron systems are most relevant to mechanistic studies on the NO-reductases,[74] we will not further address the $S=3 / 2$ systems in this article.

For $S_{\mathrm{t}}=1 / 2$ with a low spin $\mathrm{d}^{6}$ metal, the single electron must occupy the lower energy $\pi^{*}{ }_{\mathrm{NO}}$ orbital, and a $\sigma$ bond can be established with the vacant $\mathrm{d}_{\mathrm{z} 2}$ metal orbital, leading to a delocalized singly occupied molecular orbital (SOMO) over the Fe-N-O subunit, $\pi^{*}{ }_{\text {NO,dz2 }}$ (Fig.1B).[6] Figure 8 shows the latter bonding interaction, exemplified by a 6C ferrous heme nitrosyl with an axial histidine, and the antibonding combination of $\mathrm{d}_{\mathrm{z} 2}$ with the $\sigma$-orbital of histidine. The $\sigma$-trans effect of NO manifests in the competition of the $\sigma$-donor orbitals, $\pi^{*}{ }_{\mathrm{NO}}\left(\pi^{*}{ }_{\mathrm{h}}\right.$ in Figure 8$)$ and $\sigma$ (his), for the iron $\mathrm{d}_{\mathrm{z} 2}$ orbital.

A weakening (or eventually breaking) of the Fe-L ligand trans to NO can lead to either CNs 6 or 5 respectively, both biologically relevant. Given the non-zero spins, EPR is particularly informative on the detailed electronic structure, together with IR, MCD and Mössbauer spectroscopies, and X-ray diffraction.[45,75]
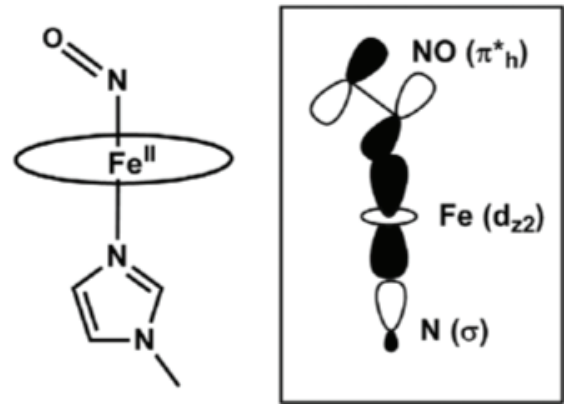

Figure 8. The key $\sigma$-bonding orbital for $6 \mathrm{C}$ heme-nitrosyls. From reference 113. 


\begin{tabular}{|c|c|c|c|c|c|c|c|}
\hline Compound & $S_{t}$ & $\begin{array}{l}v_{\mathrm{N}-\mathrm{O}} \\
-1 \\
\left(\mathrm{~cm}^{-1}\right)\end{array}$ & $\mathrm{d}_{\mathrm{M}-\mathrm{N} 0}(\AA)$ & $\begin{array}{l}d_{N-0} \\
(\AA)\end{array}$ & $\begin{array}{c}\angle_{\mathrm{MNO}} \\
\left({ }^{\circ}\right)\end{array}$ & $\begin{array}{l}\mathbf{d}_{\mathrm{M}-\mathrm{L}} \\
(\mathbb{A})\end{array}$ & Ref \\
\hline \multicolumn{8}{|l|}{ 6C } \\
\hline $\mathrm{Na}_{3}\left[\mathrm{Fe}(\mathrm{CN})_{5}(\mathrm{NO})\right] \cdot 2 \mathrm{NH}_{3}$ & $1 / 2$ & $\begin{array}{c}(1650) \\
1608^{\mathrm{b}}\end{array}$ & $(1.737)$ & $(1.199)$ & $(146.6)$ & (1.914) & 49,76 \\
\hline$[\mathrm{Fe}(\mathrm{cyclam}-\mathrm{ac})(\mathrm{NO})]\left(\mathrm{PF}_{6}\right)$ & $1 / 2$ & $\begin{array}{c}1615 \\
(1600)\end{array}$ & $\begin{array}{c}1.722 \\
(1.723)\end{array}$ & $\begin{array}{c}1.167 \\
(1.204)\end{array}$ & $\begin{array}{c}148.7 \\
(140.6)\end{array}$ & $\begin{array}{c}2.012 \\
(1.981)\end{array}$ & 30 \\
\hline$\left[\mathrm{Mb}^{\mathrm{II}} \mathrm{NO}\right]^{\mathrm{c}}$ & $1 / 2$ & 1613 & $1.76(2)$ & $1.12(1)$ & $150(2)$ & $2.05(2)$ & 31 \\
\hline$[\mathrm{Fe}(\mathrm{TPP})(\mathrm{MI})(\mathrm{NO})]^{\mathrm{d}}$ & $1 / 2$ & 1630 & 1.750 & 1.182 & 138 & 2.173 & 77 \\
\hline$[\mathrm{Fe}($ por $)(\mathrm{SPh})(\mathrm{NO})]$ & $1 / 2$ & $(1617)$ & $(1.766)$ & $(1.194)$ & (139) & $(2.513)$ & 6 \\
\hline$\left[\mathrm{Ru}\left(\mathrm{Me}_{3}[9] \mathrm{aneN}_{3}\right)(\mathrm{bpy})(\mathrm{NO})\right]\left(\mathrm{BF}_{4}\right)_{2}^{\mathrm{e}}$ & $1 / 2$ & $\begin{array}{c}1611 \\
(1620)\end{array}$ & $\begin{array}{c}1.852(2) \\
(1.90)\end{array}$ & $\begin{array}{c}1.177(3) \\
(1.22)\end{array}$ & $\begin{array}{c}141.6(2) \\
(142.4)\end{array}$ & $\begin{array}{c}2.169(2) \\
(2.22)\end{array}$ & 38 \\
\hline$\left[\mathrm{Ru}\left(\mathrm{Me}_{3}[9] \mathrm{aneN}_{3}\right)(\mathrm{bpym})(\mathrm{NO})\right]\left(\mathrm{BF}_{4}\right)_{2}^{\mathrm{e}}$ & $1 / 2$ & $\begin{array}{c}1606 \\
(1614)\end{array}$ & $\begin{array}{c}1.851(2) \\
(1.90)\end{array}$ & $\begin{array}{c}1.184(3) \\
(1.22)\end{array}$ & $\begin{array}{c}141.2(2) \\
(142.1)\end{array}$ & $\begin{array}{c}2.166(2) \\
(2.22)\end{array}$ & 39 \\
\hline \multicolumn{8}{|l|}{$5 \mathrm{C}$} \\
\hline$\left(\mathrm{NEt}_{4}\right)_{2}\left[\mathrm{Fe}(\mathrm{CN})_{4}(\mathrm{NO})\right] \mathrm{sqp}$ & $1 / 2$ & $1755^{\mathrm{f}}$ & 1.565 & 1.161 & 177.1 & & 78 \\
\hline$[\mathrm{Fe}(\mathrm{TPP})(\mathrm{NO})$ sqp & $1 / 2$ & 1697 & 1.740 & 1.42 & 146 & & 79 \\
\hline$\left[\mathrm{Fe}\left(\mathrm{TPPBr}_{8}\right)(\mathrm{NO})\right] \mathrm{sqp}^{\mathrm{g}}$ & $1 / 2$ & $1726^{\mathrm{e}}$ & $\begin{array}{c}1.75 \\
(1.711)\end{array}$ & $\begin{array}{c}1.42 \\
(1.182)\end{array}$ & $\begin{array}{c}146 \\
(144.4)\end{array}$ & & 80,81 \\
\hline \multicolumn{8}{|c|}{$\begin{array}{l}\text { a) Calculated DFT data in parenthesis. b) } v_{\mathrm{N}-\mathrm{O}} \text { in nujol. c) Geometrical data by XAFS; } v_{\mathrm{N}-\mathrm{O}} \text { by resonance Raman. d) } \\
\left.\text { DFT calculations in ref. } 77 \text {. e) } v_{\mathrm{N}-\mathrm{O}} \text { in ATR mode. f) } v_{\mathrm{N}-\mathrm{O}} \text { in } \mathrm{CH}_{3} \mathrm{CN} . \mathrm{g}\right) \text { X-ray exp. and DFT calculated values, from } \\
\text { refs. } 80 \text { and } 81 \text {, respectively. }\end{array}$} \\
\hline
\end{tabular}

\subsection{1. $6 \mathrm{C}$ complexes}

All indicators agree with the population of the $\pi^{*}{ }_{\text {MNO }}$ orbital upon reduction of the $\mathrm{n}=6$ species, supporting a Fe ${ }^{\mathrm{II}} \mathrm{NO}^{*}$ dominant electron distribution. Values of $v_{\mathrm{N}-\mathrm{O}}$ at $1610-1650 \mathrm{~cm}^{-1}$ are much lower by $\sim 300 \mathrm{~cm}^{-1}$. A significant decrease has been also found for the stretching mode $v_{\mathrm{Fe}-\mathrm{NO}}$ (viz., from $580 \mathrm{~cm}^{-1}$ in the $\mathrm{n}=6[\mathrm{Fe}(\mathrm{TPP})(\mathrm{NO})(\mathrm{MI})]^{+} \operatorname{complex}^{6}$ to $\sim 440$ $\mathrm{cm}^{-1}$ in [Fe(TPP)(NO)(MI)], (with the $\delta_{\mathrm{FeNO}}$ bending mode assigned at $\sim 560 \mathrm{~cm}^{-1}$ ). [77] The force constants were reported at 2.57 and $11.55 \mathrm{mdyn} / \AA$ for $v_{\mathrm{Fe}-\mathrm{NO}}$ and $v_{\mathrm{N}-\mathrm{O}}$, respectively. In addition to $\mathrm{Mb}^{\mathrm{II}} \mathrm{NO}$, other proteins like bovine heart $\mathrm{CCO}^{\mathrm{II}}$ NO and P450cam ${ }^{\mathrm{II}}-\mathrm{NO}$ reproduce the IR data. The $\angle \mathrm{MNOs}$ drop to $140-150^{\circ}$, and both $\mathrm{d}_{\mathrm{M}-\mathrm{NO}}$ and $\mathrm{d}_{\mathrm{N}-\mathrm{O}}$ are consistently enlarged.[6,10]

The $\mathrm{Fe}^{\mathrm{II}} \mathrm{NO}{ }^{*}$ distribution has been confirmed by Mössbauer spectroscopy; the greater and smaller values of $\delta$ and $\Delta E_{\mathrm{Q}}$ with respect to $n=6$ systems do not reflect oxidation state changes at the iron site but the different degrees of backbonding with the changing chemical character of the NO ligand. The $\pi$-acceptor abilities have been proposed to follow the trend $\mathrm{NO}^{+}>\mathrm{CO}>\mathrm{NO}^{*}{ }^{30}$

EPR studies with the series of $\left[\mathrm{M}(\mathrm{CN})_{5}(\mathrm{NO})\right]^{3-}$ anions $(\mathrm{M}=\mathrm{Fe}, \mathrm{Ru}, \mathrm{Os})$, generated in situ by reducing the $\mathrm{NO}^{+}-$ precursors in $\mathrm{CH}_{3} \mathrm{CN}$ frozen solutions at $3.5 \mathrm{~K}$, yielded a detailed picture of the influence of changing the metals for a same coligand environment.[82] The typical axial spectra with one ${ }^{14} \mathrm{~N}$ hyperfine coupling constant are diagnostic of the main $\mathrm{M}^{\mathrm{II}} \mathrm{NO}$ ' distribution. From the high-level DFT calculations, most pronounced changes in $\angle \mathrm{MNO}$ (close to $145^{\circ}$ ) and $\mathrm{d}_{\mathrm{N}-\mathrm{O}} / \mathrm{d}_{\mathrm{M}-\mathrm{NO}}$ were consistent with X-ray and IR data. The lowering of symmetry implies removal of degeneracy of the $\mathrm{e}_{2}$ orbitals, with the unpaired electron located in the $\pi^{*}{ }_{\sigma} \mathrm{SOMO}\left(\pi^{*}{ }_{\mathrm{NO}, \mathrm{dz} 2}\right)$, cf. Fig. 1B. The calculated compositions of 
the SOMO's for the three ions show that the spin density is not only confined to the nitrosyl part of the molecule (about two-thirds share on the nitrogen atom, with a sizable metal contribution). The strongly increasing spin-orbit coupling from $\mathrm{Fe}<\mathrm{Ru}<\mathrm{Os}$ has been detected through both the experimental and calculated data. The effect is most pronounced for Os, where $g_{3}$ and the calculated isotropic value $g_{\text {av }}$ are lowest and the total $g$ anisotropy $g_{1}-g_{3}$ is largest. Similar results arise from DFT data with the iron systems of Table 2: the cyclam-ac complexes and [Fe(por)(MI)(NO)]. The calculations support the smaller degree of back-bonding for NO (20\% mixture of $\pi^{*}{ }_{\sigma}$ in the bonding MO) compared to $\mathrm{NO}^{+}(28 \%)$. The EPR studies have been extended to diverse non-heme[83] and porphyrin $[84]\left[\mathrm{Ru}^{\mathrm{II}}\left(\mathrm{L}_{4}\right)(\mathrm{X})(\mathrm{NO})\right]^{\mathrm{x}}$ complexes.

A recent comprehensive EPR study with Ru-complexes allowed studying fine details on the influence of bidentate coligand variations for the $\left.\left[\mathrm{Ru}\left(\mathrm{Me}_{3}[9] \mathrm{aneN}_{3}\right)\right]\left(\mathrm{L}^{2}\right)(\mathrm{NO})\right]^{\mathrm{n}+}$ series. [39] Figure 9 shows the EPR spectra for three compounds with different $\mathrm{L}^{2}$ : 4,4'-(bpy) $\left([1-\mathrm{NO}]^{2+}\right)$, its methoxy-substituted derivative, [2-NO $]^{2+}$, and 2,2'-bipyrimidine, [3-NO $]^{2+}$ (cf. Table 2). Table 3 allows a close view to the spin-Hamiltonian parameters.

The trends in the average $g$ and $\Delta g$ values suggest an increment on the spin density on the metal fragment as the donor ability of $\mathrm{L}^{2}$ grows; also, the $A_{2}$ hyperfine coupling tensor indicates a decrease in the spin density on the $\mathrm{N}$ atom of $\mathrm{NO}$ along the same series. It was concluded that both trends are due to higher spin delocalization from the NO ligand to ruthenium with increasing donor properties of $\mathrm{L}^{2}$, which seemed counterintuitive in principle, though confirmed by the results in Table 4 on the computation of Mülliken spin densities and the compositions of the SOMOs.[39]

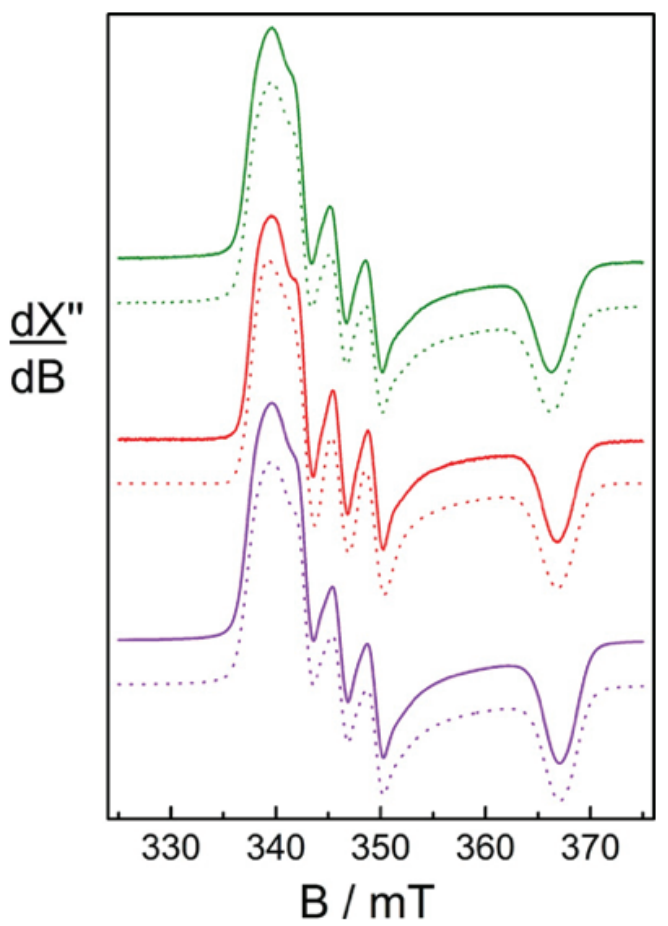

Figure 9. X-band EPR spectra of three $\left[\mathrm{Ru}\left(\mathrm{Me}_{3}[9] \operatorname{aneN}_{3}\right)\left(\mathrm{L}^{2}\right)(\mathrm{NO})\right]\left(\mathrm{BF}_{4}\right)_{2}$ compounds with different $\mathrm{L}^{2}$ coligands: 4,4'(bpy) (red, $[1 \mathrm{NO}]^{2+}$ ), its methoxy-substituted derivative, (violet, [2NO $]^{2+}$ ), and 2,2'-bipyrimidine (green, $[3 \mathrm{NO}]^{2+}$ ), in dry $\mathrm{CH}_{3} \mathrm{CN} / \mathrm{Bu}_{4} \mathrm{NPF}_{6}(0.2 \mathrm{M})$ at $85 \mathrm{~K}$. Experimental spectra as full lines and computer-simulated spectra as dotted lines. From reference 39.

Table 3. EPR Spectroscopic Data of the $\{\text { RuNO }\}^{7}$ Species $^{\text {a }}$

\begin{tabular}{|l|c|c|c|c|c|c|c|c|}
\hline & $g_{1}$ & $g_{2}$ & $g_{3}$ & $\Delta g$ & $g_{\mathrm{av}}{ }^{\mathrm{b}}$ & $A_{1}$ & $A_{2}$ & $A_{3}$ \\
\hline$[\mathbf{3 - N O}]^{2+}$ & $2.0312(1)$ & $1.9926(1)$ & $1.8823(1)$ & $0.1488(2)$ & $1.9697(1)$ & $12.1(2)$ & $30.42(9)$ & n.d. \\
\hline$[\mathbf{1 - N O}]^{2+}$ & $2.0303(1)$ & $1.9916(1)$ & $1.8792(1)$ & $0.1511(1)$ & $1.9681(1)$ & $10.96(7)$ & $30.35(5)$ & n.d. \\
\hline$[\mathbf{2 - N O}]^{2+}$ & $2.0307(1)$ & $1.9911(1)$ & $1.8780(1)$ & $0.1527(2)$ & $1.9676(1)$ & $12.7(1)$ & $29.8(1)$ & n.d. \\
\hline
\end{tabular}

${ }^{a} \mathrm{X}$-band EPR spectra obtained in $\mathrm{CH}_{3} \mathrm{CN} / \mathrm{Bu}_{4} \mathrm{NPF}_{6}(0.2 \mathrm{M})$ at $85 \mathrm{~K} . A_{1}, A_{2}$, and $A_{3}$ are shown in units of $10^{-4} \mathrm{~cm}^{-1}$. The numbers in parentheses show the $95 \%$ confidence interval. ${ }^{b} g_{\text {av. }}$ is calculated from $g_{\text {av. }}=\left[\left(g^{2}+g^{2}+g^{2}\right) / 3\right]^{1 / 2}$. n.d.: not distinguishable from 0. From reference 39. See Figure 9 for the identification of the three nitrosyl-complexes. 


\begin{tabular}{|l|c|c|c|c|}
\hline \multicolumn{5}{|c|}{ Table 4. Mülliken Spin Densities Calculated (DFT) for the $\{\mathrm{RuNO}\}^{7}$ Species.[39] } \\
\hline & Mülliken $\delta_{\text {spin }}$ & \multicolumn{2}{c|}{ Orbital composition of the SOMO / \% } \\
\hline & $\mathrm{Ru}$ & $\mathrm{NO}$ & $\mathrm{Ru}$ & $\mathrm{NO}$ \\
\hline$[\mathbf{3 - N O}]^{2+}$ & 0.0826 & 0.874 & 18.4 & 76.1 \\
\hline$[\mathbf{1 - N O}]^{2+}$ & 0.0876 & 0.871 & 19.5 & 75.2 \\
\hline$[\mathbf{2 - N O}]^{2+}$ & 0.0960 & 0.864 & 20.5 & 74.3 \\
\hline
\end{tabular}

Figure 10 represents the computed SOMO for $[1-\mathrm{NO}]^{2+}$, which results from the predominantly $\sigma$ overlap between the $\mathrm{d}_{\mathrm{z} 2}$ (and to a lower extent $\mathrm{d}_{\mathrm{xz}}$ ) Ru orbitals and the NO centered $\pi_{\text {RuNO }}^{*}$ orbital.

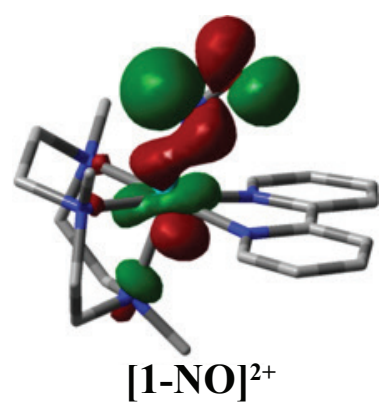

Figure 10. SOMO of the species $\left[\mathrm{Ru}\left(\mathrm{Me}_{3}[9] \mathrm{aneN}_{3}\right)\right]($ bpy $\left.)(\mathrm{NO})\right]^{2+},[1-\mathrm{NO}]^{2+}$, computed after a corresponding orbital transformation. From reference 38 .

The increase in spin delocalization from NO to Ru was ascribed to an increase in the energy of the $\mathrm{d}_{\mathrm{Ru}}$ orbitals when $\mathrm{L}^{2}$ behaves as a better donor; this draws the d-manifold closer in energy to the $\pi_{\text {RuNO }}^{*}$ orbital, thus enhancing not only the spin delocalization but most noticeably the $\sigma$-trans effect characteristic of $\{\mathrm{MNO}\}^{7}$ species, consistent with the observed lengthening of the trans Ru-N2 bond (Table 2).[39]

\subsubsection{C complexes}

We close Table 2 with results for selected 5C iron complexes, with cyanides and porphyrins as coligands. Distinctive features can be appreciated for sqp $\left.\left(\mathrm{NEt}_{4}\right)_{2}\left[\mathrm{Fe}(\mathrm{CN})_{4}(\mathrm{NO})\right]:[78] i\right) \angle \mathrm{FeNO}$ is close to linear. $i$ ) the Fe-N bond is shorter than others by $0.16 \AA$. iii) the Fe atom is most displaced upwards toward nitrosyl, by ca. $0.1 \AA$. iv) the Fe-CN distances (not shown here) are remarkably short ( $0.3 \AA$ shorter with respect to nitroprusside), revealing an enhanced $\sigma$-binding of cyanide to iron. All indicators suggest a dominant $\mathrm{Fe}^{\mathrm{I}} \mathrm{NO}^{+}$configuration, that is confirmed by the IR data showing a high upward shift of $v_{\mathrm{N}-\mathrm{O}}$ to $1746 \mathrm{~cm}^{-1}$. The EPR spectrum is also distinctive, with a $g$ value of 2.024 , interpreted in terms of coupling to a single ${ }^{14} \mathrm{~N}$ nucleus, $A\left({ }^{14} \mathrm{~N}\right)=15.2 \mathrm{G}$, and to four ${ }^{13} \mathrm{C}$ nuclei. Removal of axial cyanide from $\left[\mathrm{Fe}^{\mathrm{II}}(\mathrm{CN})_{5}(\mathrm{NO})\right]^{3-}$ to give $\left[\mathrm{Fe}(\mathrm{CN})_{4}(\mathrm{NO})\right]^{2-}$ causes the iron $d_{\mathrm{z}}^{2}$ orbital to shift from being an almost pure metal orbital to an admixed character, giving a SOMO $\sigma$-orbital bonding over the whole Fe-N-O fragment. $\left[\mathrm{Fe}^{\mathrm{II}}(\mathrm{CN})_{5}(\mathrm{NO})\right]^{3-}$ has a SOMO of $\pi$ type with respect to the FeNO direction, with $A\left({ }^{14} \mathrm{~N}\right)=38 \mathrm{G}$.

A comprehensive description of the electronic structures of $[\mathrm{Fe}(\mathrm{TPP})(\mathrm{NO})]$ and the $6 \mathrm{C}$ derivative $[\mathrm{Fe}(\mathrm{TPP})(\mathrm{MeIm})$ (NO)] has been accomplished for the first time[85] by using diverse spectroscopies: UV-vis, ${ }^{1} \mathrm{H}$ NMR, Vibrational (IR/ Raman), including isotope-substitutions and force-constant calculations by normal coordinate analysis, MCD and quantum chemical calculations. Binding equilibrium constants for diverse $\mathrm{N}$-trans ligands into the 5C species have been also determined. The $5 \mathrm{C}$ and $6 \mathrm{C}$ complexes contain $\angle \mathrm{FeNOs}$ around $140^{\circ}$ and similar medium-strong $\pi$-backbonds. For $5 \mathrm{C}$ complexes, $\sigma$ donation from the SOMO $\pi^{*}$ orbital of $\mathrm{NO}$ into $\mathrm{d}_{22}$ of $\mathrm{Fe}^{\mathrm{II}}$ forms a Fe-NO $\sigma$-bond that leads to a significant transfer of spin density from $\mathrm{NO}$ to iron; thus, the $5 \mathrm{C}$ complex has an intermediate $\mathrm{Fe}^{\mathrm{II}} \mathrm{NO} / \mathrm{Fe}^{\mathrm{I}} \mathrm{NO}^{+}$character (with $\sim 50 \%$ in Fe and NO), whilst the 6C analog shows to be a Fe ${ }^{\mathrm{II}} \mathrm{NO}^{\circ}$ complex. A similar situation holds for $5 \mathrm{C}$ [Fe( $\left.\left.\mathrm{TPPBr}_{8}\right)\left(\mathrm{NO}^{\circ}\right)\right]$. [81] 


\subsection{Labilization of trans ligands}

Some 6C complexes in Table 2 represent a generalized pattern for aqueous nitrosyls with monodentate labile transligands, to which we might add $\left[\mathrm{Fe}^{\mathrm{II}}(\mathrm{cyclam})(\mathrm{Cl})(\mathrm{NO})\right]^{+}$and $\left[\mathrm{Ru}^{\mathrm{II}}\left(\mathrm{NH}_{3}\right)_{4}(\mathrm{~L})(\mathrm{NO})\right]^{2+}$. [30,47] However, the Fe-cyclam-ac and $\mathrm{Ru}$-azamacrocycle complexes behave as robust species in solution because the trans-positions to nitrosyl are blocked by an arm of the polydentate ligand; nevertheless, the X-ray structures confirm relative elongations of the trans M-L bonds as well. The $6 \mathrm{C} \rightarrow 5 \mathrm{C}$ conversions behave as reversible equilibria, as described for the iron cyano-nitrosyls in reaction (31), with a binding constant $K_{31}=1.46 \times 10^{4} \mathrm{M}^{-1}\left(k_{\text {on }}=4.1 \times 10^{6} \mathrm{M}^{-1} \mathrm{~s}^{-1}, k_{\text {off }}=2.8 \times 10^{2} \mathrm{~s}^{-1}\right)$. [86] The value of $K_{31}$ indicates a weak trans labilization of cyanide, consistent with its strong $\sigma$-donor ability to iron. However, the $\mathrm{pH}$ influences the concentrations of $6 \mathrm{C} / 5 \mathrm{C}$ species, with the $5 \mathrm{C}$ one increasing with acidity, according to cyanide-trapping by protonation, reaction (32); thus, both species coexist $\sim 50 \%$ each at $\mathrm{pH}$ 7.4.[87] On the other hand, $6 \mathrm{C}$ iron nitrosyl hemes with weak N-binding imidazole ( $\mathrm{ImH})$ ligands have lower binding constants in the range $10-100 \mathrm{M}^{-1}$ and display stronger trans labilizations, (reaction 33).[77]

$$
\begin{aligned}
& {\left[\mathrm{Fe}(\mathrm{CN})_{4}(\mathrm{NO})\right]^{2-}+\mathrm{CN}^{-} \rightleftarrows\left[\mathrm{Fe}(\mathrm{CN})_{5}(\mathrm{NO})\right]^{3-} \quad K_{31}} \\
& \mathrm{HCN} \rightleftarrows \mathrm{CN}^{-}+\mathrm{H}^{+} \quad \mathrm{p} K_{\mathrm{a}}=9.2 \\
& {[\mathrm{Fe}(\text { por })(\mathrm{NO})]+\mathrm{ImH} \rightleftarrows[\mathrm{Fe}(\text { por })(\operatorname{ImH})(\mathrm{NO})] \quad K_{33}}
\end{aligned}
$$

The release of $\mathrm{N}$-histidine from $\mathrm{sGC}$ revealed a role for $\mathrm{NO}$ as an essential cellular signaling agent. Ensuing the very fast $\mathrm{NO}$-coordination into the $5 \mathrm{C}$ high spin $\mathrm{Fe}^{\mathrm{II}}$ center in $\mathrm{SGC}$, the transient low spin $6 \mathrm{C}$ intermediate releases the proximal histidine ligand, thus triggering a conformational change that activates the catalytic domain of the enzyme, mediating the conversion of GTP to the biochemical messenger cyclic guanosine monophosphate, cGMP, with final vasodilation. The mechanistic details on this important bioreaction are still under scrutiny; [88-90] we expand later on this issue, after discussing the chemical properties of $\left[\mathrm{Fe}(\mathrm{CN})_{5} \mathrm{NO}\right]^{3-}$ below.

\subsection{NO-ligand interchange, dinitrosyl formation and disproportionation reactions of one-electron-reduced nitroprusside. Implications for SGC activation/deactivation}

Given that the current use of nitroprusside in vascular therapy implies a rapid onset of the physiological vasodilatory response upon injection in the bodily fluids, the thiolates appeared as responsible for the build-up of $\left[\mathrm{Fe}(\mathrm{CN})_{5} \mathrm{NO}\right]^{3-}$ after addition into the $\mathrm{Fe}-\mathrm{NO}^{+}$moiety, with ensuing decay of $\left[\mathrm{Fe}(\mathrm{CN})_{5} \mathrm{NOSR}\right]^{3-}$, cf. reactions (26) and (27). $\mathrm{As}\left[\mathrm{Fe}(\mathrm{CN})_{5} \mathrm{NO}\right]^{3-}$ is inert toward NO-release $\left.\left(k_{-\mathrm{NO}}=\sim 10^{-5} \mathrm{M}^{-1} \mathrm{~s}^{-1}\right),[43] 5 \mathrm{C} \mathrm{Fe}(\mathrm{CN})_{4} \mathrm{NO}\right]^{2-}$ has been suggested as the putative NO-labile species. We afforded a detailed study on the spontaneous thermal decomposition of equilibrated solutions of $\left[\mathrm{Fe}(\mathrm{CN})_{5} \mathrm{NO}\right]^{3-}$ and $\left[\mathrm{Fe}(\mathrm{CN})_{4} \mathrm{NO}\right]^{2-}$ in the $\mathrm{pH}$ range 4-10. Scheme 3 summarizes the reactivity picture, supported by a combined use of UV-vis, IR and EPR spectroscopies.[91]

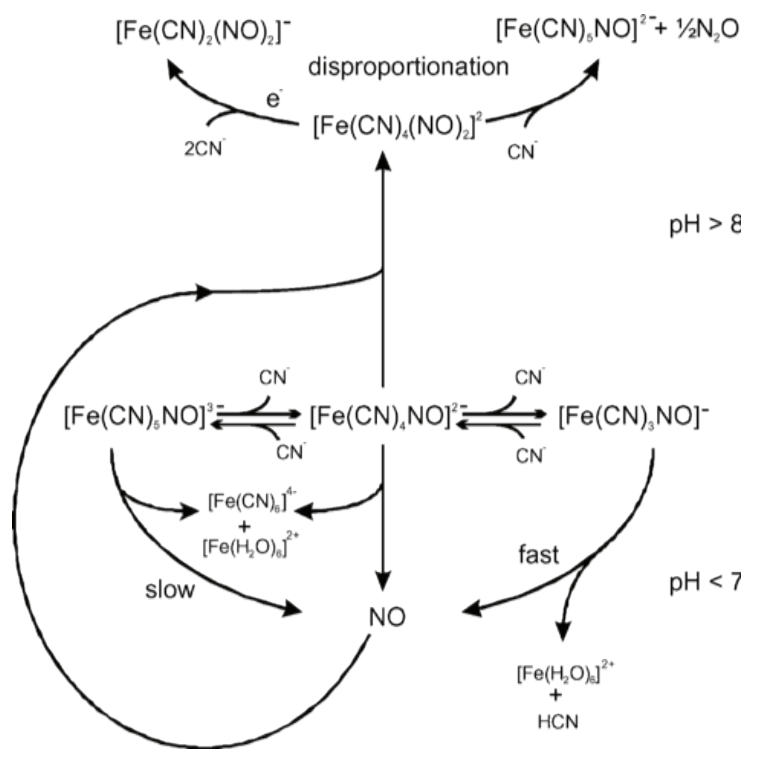

Scheme 3 
The $\mathrm{pH}$ conditions were crucial for analyzing the results. At $\mathrm{pH} 7$, initially predominant $\left[\mathrm{Fe}(\mathrm{CN})_{4} \mathrm{NO}\right]^{2-}\left(\lambda_{\max }, 615\right.$ $\mathrm{nm}$ ) decays also slowly, $k_{\text {off }} \sim 10^{-5} \mathrm{~s}^{-1}$. A faster decomposition occurs at $\mathrm{pH} 4-5$, with successive cyanide- and NO-release, forming Prussian blue-type precipitates. It has been proposed that $\left[\mathrm{Fe}(\mathrm{CN})_{4} \mathrm{NO}\right]^{2-}$ might be a precursor of fast NO-release in biorelevant media if the cyano-ligands were exposed to donor interactions with specific acceptor sites in protein residues, promoting decomposition under physiological conditions.[92] At pH $>8,\left[\mathrm{Fe}(\mathrm{CN})_{5} \mathrm{NO}\right]^{3-}\left(\lambda_{\max }, 345 \mathrm{~nm}\right)$ becomes predominant, and the slow $\mathrm{NO}^{\circ}$-release leads to the formation of an EPR-silent intermediate, $\mathrm{I}_{1}$, with a characteristic UVvis spectrum, and $v_{\mathrm{N}-\mathrm{O}}$ at $1695 \mathrm{~cm}^{-1}$. $\mathrm{I}_{1}$ is a precursor of $\mathrm{NO}$-disproportionation into $\left[\mathrm{Fe}(\mathrm{CN})_{5} \mathrm{NO}\right]^{2-}$ and $\mathrm{N}_{2} \mathrm{O}$, displaying a rigorous 1:0.5 molar stoichiometry. The IR and EPR evidence suggest that $\mathrm{I}_{1}$ is a dinitrosyl compound, $\left[\mathrm{Fe}(\mathrm{CN})_{4}(\mathrm{NO})_{2}\right]^{2-}$ (probably a trans-syn species, based on preliminary DFT calculations), proposed to be formed by self-dissociation of $\mathrm{NO}$ from $\left[\mathrm{Fe}(\mathrm{CN})_{5} \mathrm{NO}\right]^{3-}$ and rebinding into the aqua-site generated by the trans-cyanide labilization. Interestingly, a closely related complex, $\left[\mathrm{Fe}(\text { por)(NO) })_{2}\right.$, has been prepared and characterized, although at low temperatures, showing very similar DFT structural and spectroscopic properties as $\mathrm{I}_{1} \cdot[93,94]$ Thus, the identification of $\mathrm{I}_{1}$ as $\left[\mathrm{Fe}(\mathrm{CN})_{4}(\mathrm{NO})_{2}\right]^{2-}$ under room-temperature conditions is quite unusual; we confirmed a product with similar properties as $\mathrm{I}_{1}$ for the reaction of $\left[\mathrm{Fe}(\mathrm{CN})_{4} \mathrm{NO}\right]^{2-}$ with excess $\mathrm{NO}$, with $k_{\text {on }}=4.3 \times 10^{4} \mathrm{M}^{-1} \mathrm{~s}^{-1}$. [91] Remarkably, the decay of $\mathrm{I}_{1}$ leads to a new EPR active intermediate $\mathrm{I}_{2}$, indicative of the so-called " $g=2.03$ " dinitrosyls, which are biologically relevant and labile species, active toward vasodilation. [92] These $\left[\mathrm{Fe}(\mathrm{L})_{2}(\mathrm{NO})_{2}\right]$ complexes have a pseudo-tetrahedral arrangement for $\mathrm{L}=$ thiolates, imidazolates, and likely for cyanide as well.

We consider useful to analyze the above results in the context of available data on the mechanism of sGC activation. Although the crystal structure of the complete protein is lacking, sGC is known to be a heterodimer with two $\alpha-\beta$ subunits, one of them $(\beta)$ containing a high spin $5 \mathrm{C}$ ferrous heme with proximal histidine coordination. [88] It is accepted that the first step comprises fast NO binding $\left(k_{\text {on }}=4.5 \times 10^{8} \mathrm{M}^{-1} \mathrm{~s}^{-1}\right)$ giving a highly reactive $6 \mathrm{C}$ NO complex as a precursor of histidine release and consequent enzyme activation, implying a structural reordering that leads to vasodilation. Based on a measured second order rate law in NO found for the activation rate of sGC under excess NO-conditions, the formation of a dinitrosyl intermediate has been under controversy when considering the detailed mechanistic issues.[88] From recent work under physiological conditions it might be assumed that the dinitrosyl species does not form. [89,90] Estrin and coworkers studied a functional heme analog of sGC, cytochrome c', which includes three amino acid residues positioned near the distal and proximal sites.[95] Figure 11 shows a calculated structure corresponding to the first 6C intermediate, still containing bound histidine.

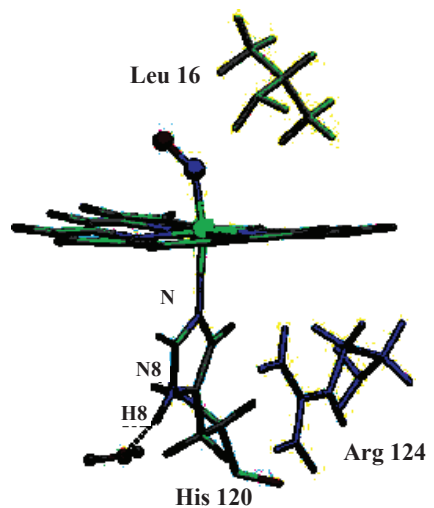

Figure 11. Calculated first 6C NO-intermediate upon reaction of cyt c' (from AXCP, alcaligenes xylosoxidans) with NO. From reference 95 .



Figure 12. 6C di-NO complex in cyt c' from AXCP (alcaligenes xylosoxidans), proposed to be formed upon histidine displacement in the complex of Figure 11 by a second NO. From reference 95. 
The conditions for the histidine release have been studied in detail, and Scheme 4 has been proposed for the successive steps during the activation process.[95] After the first NO-binding event, the $6 \mathrm{C}$ reactive intermediate leads to a $5 \mathrm{C}-\mathrm{NO}$ heme complex and free histidine, in a spontaneous uncatalyzed process, $k_{\text {act }}(4)$. Under excess NO, a faster activation ensues under a second-order regime, $k_{\text {act }}(3)$. Whilst the first $6 \mathrm{C} \rightarrow 5 \mathrm{C}$ slow conversion contains a NO bound at the distal site, the fast process leads to additional NO-binding at the proximal site, either through direct occupation of the free site arising after histidine release, or through a concerted interchange of histidine with NO. Figure 12 shows a calculated structure for the $6 \mathrm{C}$ dinitrosyl intermediate, surprisingly like the one experimentally found and calculated for [Fe(por) $\left.(\mathrm{NO})_{2}\right],[93,94]$ as well as for $\left[\mathrm{Fe}(\mathrm{CN})_{4}(\mathrm{NO})_{2}\right]^{2-}\left(\mathrm{I}_{1}\right) \cdot[91]$

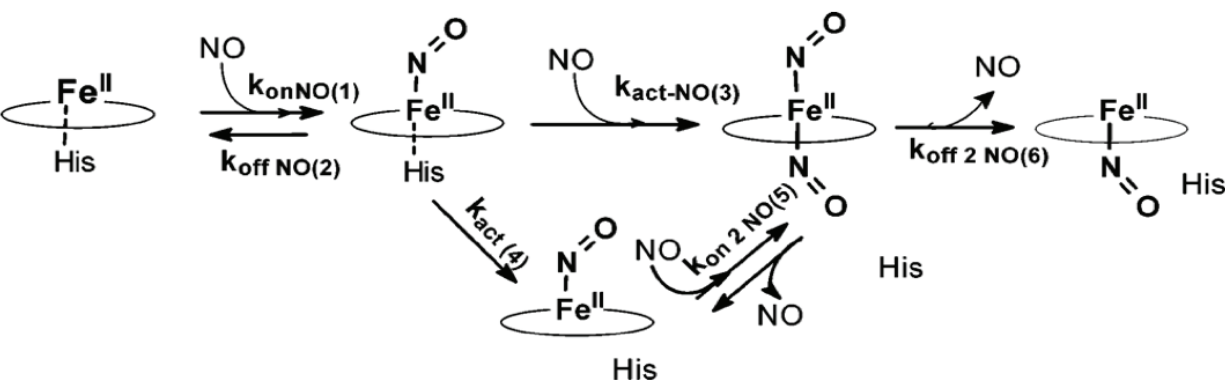

\section{Scheme 4}

The final step implies a release of NO giving a 5C-NO heme. How the second NO is released with histidine rebinding for the active site regeneration remains unknown, however. In their comprehensive study, the authors extended the analysis of the activation process to the movements of free histidine 120 and arginine 124 residues in the proximal environment, as well as a leucine 16 in the distal one (see Figure 11). We will not extend here on the relevance of the latter studies for comparing with the role of sGC, for which many structural mechanistic questions are still unsolved. Instead, we believe that given the general instability of the dinitrosyl species and the demonstrated disproportionation route for $\left[\mathrm{Fe}(\mathrm{CN})_{4}(\mathrm{NO})_{2}\right]^{2-}\left(\mathrm{I}_{1}\right)$, the cyt c' intermediate could also lead to bound $\mathrm{NO}^{-} / \mathrm{HNO}$ and $\mathrm{NO}^{+}$at the proximal and distal sites, respectively, as suggested by a calculated linear Fe-N-O group at an energy minimum of the distal site,[95] suggesting a fleeting $\mathrm{NO}^{+}$-character and a putative site for thiolate attack followed by RSNO formation and release. Besides, the strong donor $\mathrm{NO}^{-}$at the proximal site might facilitate the ligand release at the distal site and/or react with the excess NO either through $\mathrm{NO}^{-} / \mathrm{NO}$ interchange or $\mathrm{N}_{2} \mathrm{O}$ release. The latter reactivity modes could lead to final rebinding of histidine and recovery of the high spin $5 \mathrm{C} \mathrm{Fe}^{\mathrm{II}}$ resting state, allowing for the catalytic turnover steps evolving through the $6 \mathrm{C}$ mono- and di-nitrosyls. Whilst the relevance of a role for a second NO in the regulation of the conformational protein change seems well supported by the kinetic data, the full reactivity route for the dinitrosyl intermediate (eventually comprising a third NO molecule reacting with the dinitrosyl), might merit further consideration by the biochemical community.

\subsection{Nucleophilic reactivity toward $\mathrm{O}_{2}$ (dioxygenation reactions)}

A nucleophilic reactivity might be anticipated for the electron-rich NO-complexes. This has been observed for $\left[\mathrm{Fe}(\mathrm{CN})_{5}(\mathrm{NO})\right]^{3-}$ (under excess cyanide conditions), and reaction (34) describes the stoichiometry.[96]

$4\left[\mathrm{Fe}(\mathrm{CN})_{5} \mathrm{NO}\right]^{3-}+\mathrm{O}_{2}+2 \mathrm{H}_{2} \mathrm{O} \rightarrow 4\left[\mathrm{Fe}(\mathrm{CN})_{5} \mathrm{NO}^{2-}+4 \mathrm{OH}^{-}\right.$

A second-order rate law operates: $-1 / 4 \mathrm{~d}\left[\mathrm{Fe}(\mathrm{CN})_{5} \mathrm{NO}^{3-}\right] / \mathrm{dt}=k_{34}\left[\mathrm{Fe}(\mathrm{CN})_{5} \mathrm{NO}^{3-}\right]\left[\mathrm{O}_{2}\right]$, with $k_{34}=(3.5 \pm 0.2) \times 10^{5} \mathrm{M}^{-1} \mathrm{~s}^{-1}$ at $25^{\circ} \mathrm{C}, \mathrm{pH} 10$. The rate constant was insensitive to changes in $\mathrm{pH}(9-11)$ and ionic strength $(0.1-1 \mathrm{M})$. However, for $\mathrm{pH}<10$ and without added cyanide, the oxidation rate decreased markedly. We discarded an initial outer-sphere electron transfer step, given the endergonic barrier for the one-electron $\mathrm{O}_{2}$ reduction. DFT computations allowed proposing reaction (35) as an initial addition step, forming a new covalent bond between $\mathrm{NO}$ and $\mathrm{O}_{2}$, leading to an $\mathrm{Fe}^{\mathrm{III}}$-peroxynitrite species, as shown in Figure 13. In the reaction of free $\mathrm{NO}$ with $\mathrm{O}_{2}$, either ONOO or a species with some degree of association, $\mathrm{NO} \cdots$ $\mathrm{O}_{2}$ have been proposed in the first step.[15]

The process follows through the fast reactions (36) and (37), both probably involving several steps, in which the oxidation equivalents remain bound to the metal all along the full process, according with the experimentally found $4: 1$ global stoichiometry, with no other by-products.

$\left[\mathrm{Fe}^{\mathrm{II}}(\mathrm{CN})_{5} \mathrm{NO}\right]^{3-}+\mathrm{O}_{2} \rightleftarrows\left[\mathrm{Fe}^{\mathrm{III}}(\mathrm{CN})_{5} \mathrm{~N}(\mathrm{O}) \mathrm{O}_{2}\right]^{3-}$ 


$$
\begin{aligned}
& {\left[\mathrm{Fe}^{\mathrm{III}}(\mathrm{CN})_{5} \mathrm{~N}(\mathrm{O}) \mathrm{O}_{2}\right]^{3-}+\left[\mathrm{Fe}^{\mathrm{II}}(\mathrm{CN})_{5} \mathrm{NO}\right]^{3-} \rightarrow 2\left[\mathrm{Fe}^{\mathrm{III}}(\mathrm{CN})_{5} \mathrm{NO}_{2}\right]^{3-}} \\
& {\left[\mathrm{Fe}^{\mathrm{III}}(\mathrm{CN})_{5} \mathrm{NO}_{2}\right]^{3-}+\left[\mathrm{Fe}^{\mathrm{II}}(\mathrm{CN})_{5} \mathrm{NO}\right]^{3-}+\mathrm{H}_{2} \mathrm{O} \rightarrow 2\left[\mathrm{Fe}(\mathrm{CN})_{5} \mathrm{NO}\right]^{2-}+2 \mathrm{OH}^{-}}
\end{aligned}
$$

The spin unrestricted DFT calculations provided strong evidence for identification of the first intermediate; the geometry optimization procedure demonstrates that the SOMO is localized on iron(III) and not at the terminal O-atom, with Mülliken spin densities close to one, calculated either in vacuum or in solvated conditions $\left(\mathrm{PCM}^{+} 6 \mathrm{H}_{2} \mathrm{O}\right)$. $\mathrm{Given}$ that the geometrical parameters and stretching frequencies are consistent with a bound N-peroxynitrite anion, we might discard the alternative descriptions containing either $\mathrm{Fe}(\mathrm{II})-\mathrm{N}(\mathrm{O}) \mathrm{O}_{2}$, or the $\mathrm{Fe}(\mathrm{III})-\mathrm{OON}(\mathrm{O})^{-}$isomer.

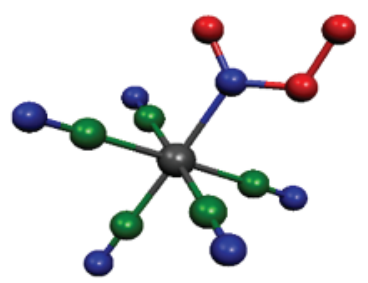

Figure 13. DFT-calculated intermediate, $\left[\mathrm{Fe}^{\mathrm{III}}(\mathrm{CN})_{5}\left(\mathrm{~N}(\mathrm{O}) \mathrm{O}_{2}\right)\right]^{3-}, \mathrm{B} 3 \mathrm{LYP} / 6-31 \uparrow \dagger$, with $\mathrm{PCM}+6 \mathrm{H}_{2} \mathrm{O}$. For $\mathrm{N}(\mathrm{O}) \mathrm{O}_{2}^{-}$bound to Fe: $\mathrm{d}(\mathrm{N}=\mathrm{O}), 1.205 \AA ; \mathrm{v}(\mathrm{N}=\mathrm{O}), 1590 \mathrm{~cm}^{-1} ; \mathrm{d}(\mathrm{N}-\mathrm{O}), 1.352 \AA, v(\mathrm{~N}-\mathrm{O}), 784 \mathrm{~cm}^{-1} ; \mathrm{d}(\mathrm{O}-\mathrm{O}), 1.369 \AA ; \mathrm{O}(\mathrm{O}-\mathrm{O}), 913 \mathrm{~cm}^{-1}$. See the Supp. Inf. in Ref. 96 for details on the calculations and other parameters derived from the geometry optimization.

Under steady state conditions for $\left[\mathrm{Fe}^{\mathrm{III}}(\mathrm{CN})_{5} \mathrm{~N}(\mathrm{O}) \mathrm{O}_{2}\right]^{3-}$, and using a limiting approach, a first-order rate law in each reactant is obtained, with $k_{35}=k_{\mathrm{ad}}=k_{\mathrm{O} 2}$. Second order rate laws have been found for the autoxidation reactions of other nitrosyl complexes with $\mathrm{n}=7$. [97,99] Figure 14 displays a plot of $\ln k_{\mathrm{O} 2}$ against $E_{\mathrm{NO}+\mathrm{NO}}$.

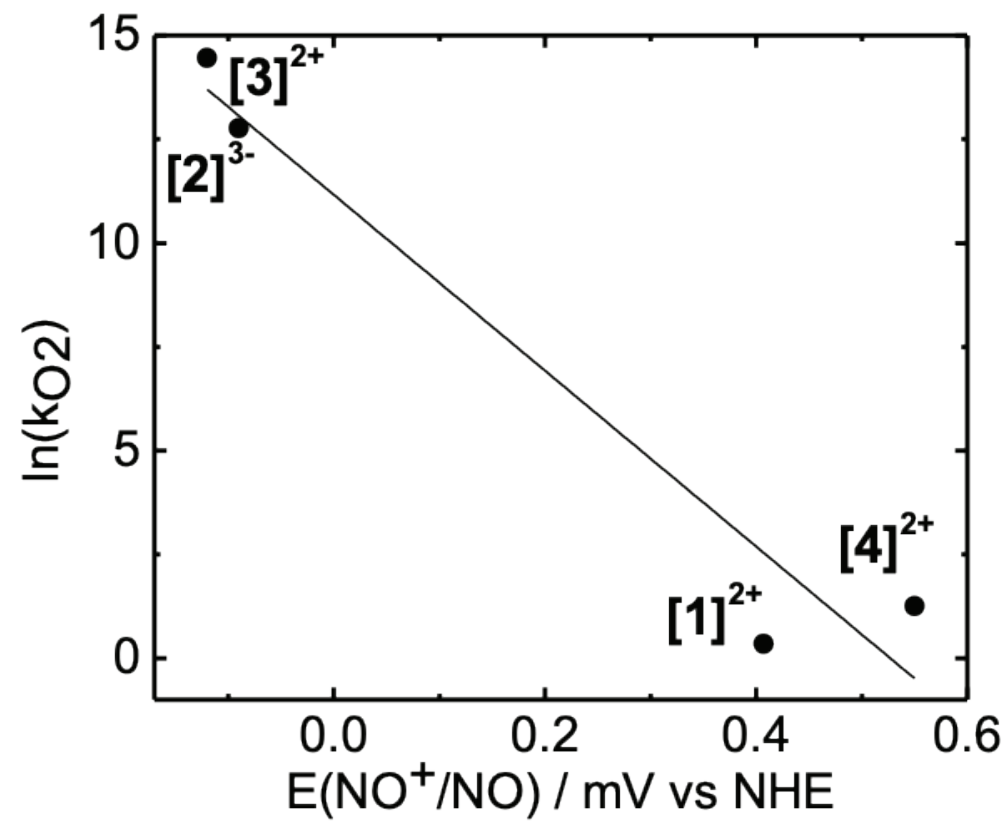

Figure 14. Plot of $\ln k_{\mathrm{O} 2} v s E_{\mathrm{NO}+} /$ NO for the reactions of $\mathrm{O}_{2}$ with different complexes: [1]: $\left[\mathrm{Ru}\left(\mathrm{Me}_{3}[9] \mathrm{aneN}_{3}\right)(\mathrm{bpy})\right.$ $(\mathrm{NO})]^{2+} ;[97][2]:\left[\mathrm{Fe}^{\mathrm{II}}(\mathrm{CN})_{5}(\mathrm{NO})\right]^{3-} ;[97][3]:\left[\mathrm{Ru}^{\mathrm{II}}\left(\mathrm{NH}_{3}\right)_{5}(\mathrm{NO})\right]^{2+},[98]$ and $\left.[4]: \mathrm{Ru}^{\mathrm{II}}(\mathrm{bpy})(\mathrm{tpm})(\mathrm{NO})\right]^{2+}$.[99] Extracted from reference [97].

The negative slope of $-21 \pm 1 \mathrm{~V}^{-1}$ agrees with the theoretical Marcus-type behavior for bimolecular reactions with associative character. Indeed, a better correlation might be expected by including data for new complexes, preferentially in the mid-potential region. The slow-reacting complexes display significant deviations, as also observed for $\mathrm{Mb}^{\mathrm{II}} \mathrm{NO}$, 
for which a corresponding point was included in a similar plot;[12] (it could be added in Fig. 14, close to [1] $]^{2+}$ ). The deviations are not unexpected, due to the possible competing NO-dissociation in the rate-determining step $\left(k_{\text {off(NO) }} \sim 10^{-4}\right.$ $\mathrm{s}^{-1}$ for $\left.\mathrm{Mb}^{\mathrm{II}} \mathrm{NO}\right)$. [12,96] On the other hand, the autoxidation of the electron rich complex $\left[\mathrm{Ru}^{\mathrm{II}}(\mathrm{DMAP})_{4}(\mathrm{NO})(\mathrm{OH})\right]^{+}$was unmeasurably fast (we estimate a point at the upper-left side of the plot, out of Fig. 13).[100] Not unexpectedly, the latter figure resembles Fig. 4, bearing a positive slope, covering the electrophilic additions of $\mathrm{OH}^{-}$into $\left[\mathrm{ML}_{5}\left(\mathrm{NO}^{+}\right)\right] \mathrm{complexes}$

It can be concluded that $6 \mathrm{C}$ is a necessary condition to achieve autoxidation of NO-complexes, given the unreactivity of $5 \mathrm{C}\left[\mathrm{Fe}(\mathrm{CN})_{4} \mathrm{NO}\right]^{2-}$ at neutral/low $\mathrm{pH}$, in agreement with the electron push by the sixth ligand that increases the radical character of $\mathrm{NO}$ (see the previous analysis of the $\mathrm{EPR}$ results for $6 \mathrm{C} / 5 \mathrm{C}$ systems). Other $5 \mathrm{C}$ complexes were found to react with $\mathrm{O}_{2}$ in aprotic solvents, but only in the presence of a base, which allowed formation of the $6 \mathrm{C}$ reactive species. [12] Indeed, that the redox potentials of the $\mathrm{MNO}^{+} / \mathrm{MNO}^{*}$ couples could predict the NO-autoxidation reactivity is quite significant; eventually, some $\mathrm{NO}^{*}$-coordination compounds could provide a fast route for $\mathrm{NO}^{*}$-consumption, as shown below.

In the NOS-catalyzed endogenous production of $\mathrm{NO}$ by oxidation of L-arginine with $\mathrm{O}_{2}$, a $6 \mathrm{C} \mathrm{Fe}$-NO intermediate (containing cysteinate as a trans-ligand to NO) played a crucial role in the global catalytic/regulatory cycle by reacting with $\mathrm{O}_{2}$ and giving $\mathrm{NO}_{3}^{-}$, which was rapidly released.[101] In this way, regeneration of the labile aqua-site (5C high-spin $\mathrm{Fe}^{\mathrm{III}}$ ) allowed performing the catalytic turnover through subsequent reduction to $\mathrm{Fe}(\mathrm{II})$ and $\mathrm{O}_{2}$-coordination for reacting with the arginine substrate. By using variants of $\mathrm{n}$ - and i-NOS isoforms, the rate constants for dioxygenation reactions of bound $\mathrm{NO}, k_{\mathrm{O} 2}$, were found in the range $10^{2}-10^{4} \mathrm{M}^{-1} \mathrm{~S}^{-1}$, depending on the presence/absence of substrate (L-arg), cofactor $\left(\mathrm{BH}_{4}\right)$ and/or H-bonding interactions either at the distal- or proximal heme sites. Oxygen binding to the NOS ferrous heme is extremely fast (ill-defined $k_{\mathrm{O} 2}$, reported to be higher than $10^{5} \mathrm{M}^{-1} \mathrm{~s}^{-1}$ ), [101] and thus the corresponding point might be well located up- and left-wards (out of the plot) in Figure 14. Thus, the mechanisms appear to be similar for the heme- and non heme systems (both affording N-bound peroxynitrite initial intermediates), by using the values of $k_{\mathrm{O} 2}$ por pure NOS and $E_{\mathrm{NO}+\mathrm{NO}}(\sim-0.3 \mathrm{~V})$. However, the smaller denitrosylation rates for the NOS-surrogates lead to strong deviations. This is not a surprise, given that in contrast to the diffusional encounter of reactants for the non heme nitrosyls, a restricted access of $\mathrm{O}_{2}$ to the distal pocket has been demonstrated for the NOS isozymes;[101] thus, the rates are not controlled solely by $k_{\mathrm{O} 2}$ (direct reactivity of $\mathrm{O}_{2}$ to nitrosyl), and therefore the observed denitrosylation rates become much lower for the enzymatic systems.

\section{Strongly bent $6 \mathrm{C}$ and $5 \mathrm{C}\{\mathrm{MNO}\}^{8}$ complexes. Highly reducing and nucleophilic}

The title compounds containing $\mathrm{Fe}^{\mathrm{II}}$ and $\mathrm{Ru} \mathrm{II}^{\mathrm{II}}$ centers have been generated (and sometimes isolated) from one-electron electrochemical or chemical reductions of the $\{\mathrm{MNO}\}^{7}$ analogs using hydrides, dithionite, cobaltocene, etc., under anaerobic conditions in non-aqueous media. Aqueous $\mathrm{Co}^{\mathrm{III}}-\mathrm{NO}^{-}$complexes can be generated through oxidation of $\mathrm{Co}^{\mathrm{II}}$ reactants. There is a need of well characterized iron complexes in aqueous solutions. [17]

Figure $1 \mathrm{~b}$ shows that for $\mathrm{n}=8$ conditions either both $\pi^{*}{ }_{\mathrm{NO}}$ MOs can be $\operatorname{singly}$ occupied $\left(S_{\mathrm{t}}=1\right)$, or two electrons can fully locate at the lower energy orbital $\left(S_{\mathrm{t}}=0\right)$. In the latter case, both $6 \mathrm{C}$ and $5 \mathrm{C}$ compounds might be predicted, though $5 \mathrm{C}$ is likely favored, given the very strong trans interaction associated with the most pronounced $\sigma$ donation from $\pi^{*}{ }_{\text {NO }}$ to $\mathrm{d}_{\mathrm{z} 2}$, with an increase in the antibonding character of the trans M-L bond. As shown below, these predictions are well realized.[102]

Table 5 show selected examples for $6 \mathrm{C}$ and $5 \mathrm{C}$ situations. We include the scarce examples of related Fe- and $\mathrm{Ru}-$ complexes already displayed in Tables 1 and 2, namely those containing the same coligands. The Co-examples reflect the abundance of this metal for binding nitroxyl ligands, which becomes useful here for searching in the bonding changes upon metal variations.[103,104] 


\begin{tabular}{|c|c|c|c|c|c|c|c|}
\hline Compound & $S_{t}$ & $\begin{array}{c}v_{\mathrm{N}-\mathrm{O}} \\
\left(\begin{array}{c}-1 \\
(\mathrm{~cm})\end{array}\right)\end{array}$ & $\begin{array}{c}d_{\text {M-NO }} \\
(\mathbb{A}) \\
\end{array}$ & $\begin{array}{l}d_{\mathrm{N}-0} \\
(\AA)\end{array}$ & $\begin{array}{c}\angle_{\mathrm{MNO}} \\
0 \\
0 \\
\end{array}$ & $\begin{array}{l}d_{M-L} \\
(\AA) \\
(\AA)\end{array}$ & Ref \\
\hline \multicolumn{8}{|l|}{$6 \mathrm{C}$} \\
\hline$\left[\mathrm{Fe}(\text { cyclam-ac)NO }]^{a}\right.$ & 0 & $1271^{\mathrm{b}}(1274)$ & $(1.752)$ & $(1.261)$ & $(122.4)$ & $(2.127)$ & 30 \\
\hline$\left[\mathrm{Ru}^{2}\left(\mathrm{Me}_{3}[9] \mathrm{aneN}_{3}\right)(\mathrm{bpy})(\mathrm{NO})\right]^{+}$ & 0 & $1315^{\mathrm{c}}(1404)$ & $(1.91)$ & $(1.27)$ & $(122.9)$ & $(2.41)$ & 39 \\
\hline$\left[\mathrm{Co}(\mathrm{en})_{2}(\mathrm{Cl})(\mathrm{NO})\right]^{+}$ & 0 & 1611 & $1.820(11)$ & $1.043(17)$ & $124.4(11)$ & & 103 \\
\hline \multicolumn{8}{|l|}{$5 \mathrm{C}$} \\
\hline$\left[\mathrm{Fe}(\mathrm{CN})_{4}(\mathrm{NO})\right]^{3-}$ tbp, ${ }^{\mathrm{e}}$ & 0 & $(1581)$ & $(1.637)$ & $(1.22)$ & $(171.2)$ & & 46 \\
\hline$[\mathrm{Co}(\mathrm{TPP})(\mathrm{NO})] \mathrm{sqp}$ & 0 & 1681 & 1.830 & 1.149 & 123.4 & & 104 \\
\hline$\left[\mathrm{Fe}\left(\mathrm{TPPBr}_{8}\right)(\mathrm{NO})\right]^{-} \mathrm{sqp}^{\mathrm{f}}$ & 0 & $1540^{\mathrm{g}}$ & $1.814(4)$ & $1.194(5)$ & $122.4(3)$ & & 105 \\
\hline
\end{tabular}

a) Values in parenthesis are from DFT calculations. b) in $\mathrm{CD}_{3} \mathrm{CN}$ solution. c) in $\mathrm{CH}_{3} \mathrm{CN}$ solution. d) isolated as a $\mathrm{ClO}_{4}^{-}$salt. e) not isolated, only DFT data. It is probably a product of the NMR titration of $\left[\mathrm{Fe}(\mathrm{CN})_{5}(\mathrm{HNO})\right]^{3-}$ with $\mathrm{OH}^{-}$, after reaching $\mathrm{pH} 10$, see text and Figure 15. f) Structural data from an isolated $\mathrm{Co}(\mathrm{Cp})_{2}^{+}$salt; corresponding DFT calculations in ref. 81. g) in $\mathrm{CH}_{2} \mathrm{Cl}_{2}$ solution or as an evaporated solid film, ref. 81.

For [ Fe(cyclam-ac)(NO)], the pronounced bending of $\angle \mathrm{FeNO}$ (near $120^{\circ}, \mathrm{sp}^{2}$ nitrogen), the elongated bonds in the Fe-N-O moieties, and a notoriously low value of $v_{\mathrm{N}-\mathrm{O}}$ at $1271 \mathrm{~cm}^{-1}$, confirmed by isotopic labelling and theoretical calculations, allowed proposing a low-spin Fe" $\mathrm{NO}^{-}$distribution, supported by $S_{\mathrm{t}}=0$ and Mössbauer results.[30] A similar behavior of


as compared to the $\mathrm{n}=6,7$ analogs.[39] The $\mathrm{NO}^{-}$ligand appears to engage in stable $\mathrm{M}^{\mathrm{II}}$-NO- bonds in both complexes, inert to dissociation. Though still not able to release the trans-ligand, the enhanced trans-releasing effect manifests in the elongation of the trans $\mathrm{Fe}-\mathrm{O}$ and $\mathrm{Ru}-\mathrm{N}_{(2)}$ bonds by 0.15 and $0.19 \AA$ respectively with respect to the corresponding $\mathrm{n}=7$ complexes. A detailed look at all indicators for both $\mathrm{Fe}$ and $\mathrm{Ru}$ series demonstrate that the back bonding acceptor capacity of the nitrosyl group increases strongly according to $\mathrm{NO}^{-}<\mathrm{NO}<\mathrm{NO}^{+}$, with conversion from a strong nucleophile to a strong electrophile. Interestingly, the $6 \mathrm{C} \mathrm{Co}{ }^{\text {III }}$ nitroxyl complex shows an increased value of $v_{\mathrm{N}-\mathrm{O}}$, probably related to the weaker $\pi$-interaction for $\mathrm{M}^{\mathrm{III}}$ as compared to $\mathrm{M}^{\mathrm{II}}$ centers.[103] The nitroxylcobalamine analog (NOCbl, not shown) behaves similarly.[12]

Notoriously, there is no $6 \mathrm{C}\left[\mathrm{Fe}(\mathrm{CN})_{5}(\mathrm{NO})\right]^{4-}$ complex in Table 5; it was calculated by DFT as unstable in water, leading to $5 \mathrm{C}$ tbp $\left[\mathrm{Fe}(\mathrm{CN})_{4}(\mathrm{NO})\right]^{3-}$ upon cyanide release.[46] Similarly, $6 \mathrm{C}[\mathrm{Fe}(\mathrm{NO})(\mathrm{Cl})(\mathrm{cyclam})]$ decomposes readily by releasing the chloride ligand in $\mathrm{CH}_{3} \mathrm{CN}$.[30] The DFT data for $5 \mathrm{C}$ tbp $\left[\mathrm{Fe}(\mathrm{CN})_{4}(\mathrm{NO})\right]^{3-}$ (not isolated) shows a close to linear $\angle \mathrm{FeNO}$ and a short Fe-N distance; by also considering the value of $v_{\mathrm{N}-\mathrm{O}}$ at $1581 \mathrm{~cm}^{-1}$, an $\mathrm{Fe}^{\mathrm{I}} \mathrm{NO}$ electronic distribution was proposed, and the protonation feasibility was estimated.[46] The $5 \mathrm{C}\left[\mathrm{Fe}(\text { por)(NO)] }]^{-}\right.$was also unstable, though Table 5 includes a stable species, isolated by reducing an $\mathrm{n}=7$ electron-poor model iron porphyrin in $\mathrm{CH}_{2} \mathrm{Cl}_{2}$ with cobaltocene, leading to $\left[\mathrm{Co}\left(\mathrm{C}_{5} \mathrm{H}_{5}\right)_{2}\right]\left[\mathrm{Fe}\left(\mathrm{TFPBr}_{8}\right)(\mathrm{NO})\right] \cdot[81,105] \mathrm{It}$ has been described as having an intermediate $\mathrm{Fe}^{\mathrm{II}} \mathrm{NO} /$ $\mathrm{Fe}^{\mathrm{I} N O}$ distribution. This strategy allowed preparing a similar heme-like salt of $\left[\mathrm{Fe}\left(\mathrm{LN}_{4}\right)(\mathrm{NO})\right]$; [12] as well as a picketfence porphyrin [Fe(3,5-Me-BAFP)(NO) $]^{-}$, in THF solution.[102]

Trans labilizations and facile generation of $5 \mathrm{C}$ complexes explain the abundance of sqp Co-nitroxyl porphyrins and some $\left[\mathrm{Co}\left(\mathrm{LN}_{4}\right)(\mathrm{NO}]\right.$ analogs.[12] A common low-spin $\mathrm{Co}^{\mathrm{III}} \mathrm{NO}^{-}$electronic distribution is currently accepted for all $6 \mathrm{C}$ and $5 \mathrm{C}$ Co-complexes. On the other hand, well characterized examples with metals of the $2^{\text {nd }}$ or $3^{\text {rd }}$ transition series are known (tpb NO- complexes of $\mathrm{Os}^{\mathrm{II}}$, $\mathrm{Ir}^{\mathrm{III}}, \mathrm{Re}^{\mathrm{I}}$, and even $\mathrm{Pt}^{\mathrm{IV}}$ ).[17]

Given the extreme electron-rich character of $\mathrm{NO}^{-}$complexes, the M-N-O moieties are prone to react with electrophilic reagents. This was early observed with $5 \mathrm{C}\left[\mathrm{CoL}_{4} \mathrm{NO}\right]$ complexes $\left(\mathrm{L}_{4}\right.$, multidentate planar anions) reacting with $\mathrm{O}_{2}$ in acetone, in the presence of nitrogen- and phosphorus bases $\mathrm{B}$, to yield the corresponding $6 \mathrm{C}$ nitro-compounds, $\left[\mathrm{CoL}_{4}\left(\mathrm{NO}_{2}\right)\right.$ (B)]. The bimolecular rate constants for the $\mathrm{O}_{2}$-additions depended on the basicity of the $\mathrm{B}$ ligands trans to the nitroxyl group, and peroxynitrite intermediates have been proposed.[12,27] A similar reactivity toward $\mathrm{O}_{2}$ has been observed for the "based-on" 6C NOCbl, and for other complexes in Table 5, which indeed react with $\mathrm{O}_{2} \cdot[12]$ Like the $\mathrm{n}=7$ species, $6 \mathrm{C}$ appears as a requirement for $\mathrm{O}_{2}$-reactivity. Protonation at the nitrogen lone pair of bound- $\mathrm{NO}^{-}$is also feasible, as seen below. 


\section{HNO (nitroxyl, azanone) complexes $(n=8)$}

\subsection{Synthesis, spectroscopic characterization, and trans-L releasing ability of bound HNO}

6C HNO non heme complexes have been prepared with $\mathrm{Fe}, \mathrm{Ru}$, Os, Ir, and Re metals, with ancillary coligands, since the pioneering work leading to X-ray structures of $\left[\mathrm{Os}(\mathrm{Cl})_{2}(\mathrm{CO})\left(\mathrm{PPh}_{3}\right)_{2}(\mathrm{HNO})\right]$ and $\left.\left[\mathrm{Ir}(\mathrm{H})(\mathrm{Cl})_{2}\left(\mathrm{PPh}_{3}\right)_{2}\right)(\mathrm{HNO})\right]$. Most isolated complexes are insoluble in water. Good characterizations of bound $\mathrm{HNO}$ were achieved using ${ }^{1} \mathrm{H}$ NMR, IR, and RR spectroscopies. Both $\sigma$ and mainly $\pi$ interactions contribute to HNO stabilization upon coordination.[17] In Table 6, we first include two examples of aqueous systems comprising $\left[\mathrm{Fe}^{\mathrm{II}}(\mathrm{CN})_{5}(\mathrm{HNO})\right]^{3-}$ and $\mathrm{Mb}^{\mathrm{II}}(\mathrm{HNO})$, together with related $\mathrm{Fe}-$, Ru-, and Os-models. The values of $v_{\mathrm{N}-\mathrm{O}}$ at $1350-1390 \mathrm{~cm}^{-1}$ remain nearly constant for all complexes; remarkably, they are also coincident with the values found for diverse structurally related $\left[\mathrm{Fe}^{\mathrm{II}}(\mathrm{CN})_{5}(\mathrm{~L})\right]^{\mathrm{n}-}$ nitroso compounds, with $\mathrm{L}=\mathrm{NOBz}$, NOSR, etc.[12] The distances and angles are close to those for the $6 \mathrm{C} \mathrm{NO}-$-analogs (cf. Table 5), though $v_{\mathrm{N}-\mathrm{O}}$ affords greater values in $\mathrm{Fe}^{\mathrm{II}}$-HNO than in $\mathrm{Fe}^{\mathrm{II}}-\mathrm{NO}^{-}$, probably related to different solvations.

\begin{tabular}{|c|c|c|c|c|c|c|c|}
\hline Compound $^{\mathrm{a}}$ & $\begin{array}{l}v_{\mathrm{N}-\mathrm{O}} \\
(\mathrm{cm})\end{array}$ & $\begin{array}{l}\mathbf{d}_{\mathrm{M}-0} \\
(\boldsymbol{A})\end{array}$ & $\begin{array}{l}\mathbf{d}_{\mathrm{N}-0} \\
(\tilde{A})\end{array}$ & $\underset{\mathrm{MNO}}{\angle_{()}}$ & $\begin{array}{l}d_{\mathrm{v}-\mathrm{L}} \\
(\mathbb{A})\end{array}$ & $\begin{array}{c}{ }^{1} \mathrm{H} \text { NMR } \\
(\delta, \mathrm{ppm}) /(J \\
\mathrm{Hz})\end{array}$ & Ref. \\
\hline$\left[\mathrm{Fe}(\mathrm{CN})_{5}(\mathrm{HNO})\right]^{3-}$ & $1384^{b}$ & $(1.783)$ & $(1.249)$ & $(137.5)$ & $(1.915)$ & $20.0^{\mathrm{b}} / 71.14$ & 45,106 \\
\hline$[\mathrm{Mb}(\mathrm{HNO})]$ & $1385^{\mathrm{c}}$ & $1.82(2)$ & $1.24(1)$ & 131.6 & 2.09 & $14.8^{\mathrm{c}} / 72.5$ & 31 \\
\hline$\left[\begin{array}{l}\mathrm{Fe}(\text { cyclam-ac })(\mathrm{HNO})]^{+} \\
\end{array}\right.$ & $(1351)$ & $(1.780)$ & $(1.268)$ & $(126.3)$ & $(1.994)$ & & 30 \\
\hline$\left[\mathrm{Ru}\left(\mathrm{Me}_{3}[9] \mathrm{aneN}_{3}\right)(\mathrm{bpy})(\mathrm{HNO})\right]^{2+}$ & (1376) & $(1.93)$ & $(1.28)$ & $(127.5)$ & $(2.22)$ & & 38 \\
\hline$\left[\mathrm{Ru}\left(\mathrm{py}^{\mathrm{bu}} \mathrm{S}_{4}\right)(\mathrm{HNO})\right]^{+}$ & $1358^{\mathrm{d}}$ & $1.875(7)$ & $1.242(9)$ & $130.0(6)$ & & $19.56^{\mathrm{e}}$ & 108 \\
\hline$[\mathrm{Ru}(\mathrm{ttp})(1-\mathrm{MeIm})(\mathrm{HNO})]$ & $1380^{\mathrm{d}}$ & & & & & $13.64^{\mathrm{f}} / 71.1$ & 109 \\
\hline$\left[\mathrm{Os}(\mathrm{Cl})_{2}(\mathrm{CO})\left(\mathrm{PPh}_{3}\right)_{2}(\mathrm{HNO})\right]$ & $1410^{\mathrm{g}}$ & $1.915(6)$ & $1.193(7)$ & $136.9(6)$ & & $21.2^{\mathrm{h} / 75}$ & 110 \\
\hline
\end{tabular}

a) Data in parenthesis correspond to DFT calculations. b) $\mathrm{pH} 6$ for ATR/RR; $25 \% \mathrm{D}_{2} \mathrm{O}$ for NMR. c) geometrical and vibrational data in aqueous/glycerol at $10 \mathrm{~K}$. NMR data at $\mathrm{pH} 10$ in $\mathrm{D}_{2} \mathrm{O}$. d) in $\mathrm{KBr}$. e) in $\mathrm{THF}^{-\mathrm{d}_{8}}$. f) in $\mathrm{CDCl}_{3} . \mathrm{g}$ ) in nujol. h) in benzene- $\mathrm{d}_{6}$.

Figure 15 describes the two-step titration of aqueous nitroprusside with dithionite at $p H$ 10.[106] Just after the addition of the first drops of dithionite, a red color develops which immediately disappears upon stirring, giving a yellow-orange absorption band centered at $345 \mathrm{~nm}$ that grows steadily up to the completion of the first-equivalent reduction. This is indicative of formation of the one-electron reduced product $\left[\mathrm{Fe}(\mathrm{CN})_{5}(\mathrm{NO})\right]^{3-}$ in the first step, $[86,87]$ although seemingly not in a direct way, see below section 6.3. Through the onset of the second-equivalent reduction, the latter species decays and transforms into a final red product with $\lambda_{\max }$ at $445 \mathrm{~nm}\left(\mathrm{I}_{445}\right)$, which is moderately stable for hours, slowly turning back to $\left[\mathrm{Fe}(\mathrm{CN})_{5}(\mathrm{NO})\right]^{3-}$, with a $\mathrm{t}_{1 / 2}=50 \mathrm{~min}$. 




Figure 15. UV-vis titration ( $\left.\mathrm{pH} 10, \mathrm{~T}=25^{\circ} \mathrm{C}\right)$, of $3 \times 10^{-4} \quad \mathrm{M}\left[\mathrm{Fe}^{\mathrm{II}}(\mathrm{CN})_{5}(\mathrm{NO})\right]^{2-}(1)$ with two sequential 1-equivalent additions of $\mathrm{S}_{2} \mathrm{O}_{4}{ }^{2-}$, giving the reduced complexes: $2,\left[\mathrm{Fe}^{\mathrm{II}}(\mathrm{CN})_{5}(\mathrm{NO})\right]^{3-}$, and 3: $\mathrm{I}_{445}$. The latter product 3 is probably a mixture of two-electron reduced complexes, see text. From reference 106.

By shifting the $\mathrm{pH}$ from 10 to 6-7 immediately after the end of dithionite-titration, the absorbance maximum at $445 \mathrm{~nm}$ was maintained, and $\mathrm{I}_{445}$ became even more robust under anaerobic conditions, with an extremely slow first order decay, $k_{\text {obs }}=\sim 10^{-7} \mathrm{~s}^{-1}$. Thus, $\mathrm{I}_{445}$ did not generate $\mathrm{N}_{2} \mathrm{O}$, neither released cyanide in time scale of hours.[107] We might tentatively identify $\mathrm{I}_{445}$ (at $\mathrm{pH} 10$ ) as a mixture of two-electron reduced products, namely $\left[\mathrm{Fe}(\mathrm{CN})_{5}(\mathrm{HNO})\right]^{3-},\left[\mathrm{Fe}(\mathrm{CN})_{5}(\mathrm{NO})\right]^{4-}$, and $\left[\mathrm{Fe}(\mathrm{CN})_{4}(\mathrm{NO})\right]^{3-}$, as analyzed below.

Figure 16 shows the titration of the robust $\mathrm{I}_{445}$ complex generated at $\mathrm{pH} 6$, with $\mathrm{OH}^{-}$, as followed by ${ }^{1} \mathrm{H} \mathrm{NMR}$. The inset (top left) displays the initial NMR features, with a notoriously downfield ${ }^{1} \mathrm{H}$ signal, split into a doublet upon coupling within the ${ }^{15} \mathrm{~N}$ labeled species (Table 6). Indeed, the ${ }^{1} \mathrm{H}$ signal shows unequivocally that $\mathrm{I}_{445}$ corresponds to $\left[\mathrm{Fe}(\mathrm{CN})_{5}(\mathrm{HNO})\right]^{3-}$ at $\mathrm{pH}$ 6, also supported by complementary spectroscopic evidence (IR, RR). The intensity of the NMR signal decays along the titration, with complete disappearance in the 8.8-10 pH-range. An apparent $\mathrm{p} K_{\mathrm{a}}$ of 7.7 was assigned initially to deprotonation of $\left[\mathrm{Fe}(\mathrm{CN})_{5}(\mathrm{HNO})\right]^{3-}$ giving $\left[\mathrm{Fe}^{\mathrm{II}}(\mathrm{CN})_{5}(\mathrm{NO})\right]^{4-}$, eq 38 . That assignment was put into question by new ${ }^{17} \mathrm{O}$ NMR evidence stating that the ${ }^{17} \mathrm{O}$ signal was maintained up to $\mathrm{pH} 10$, which allowed proposing a $\mathrm{p} K_{\mathrm{a}}$ at $\sim 10-11,[111]$ more in agreement with the estimated value for $\mathrm{Mb}^{\mathrm{II}}$-HNO.[112] The intriguing 7.7 number was traced to an artifact related to a rapid H-exchange between bound HNO and water, acid and/or base-catalyzed.[111]

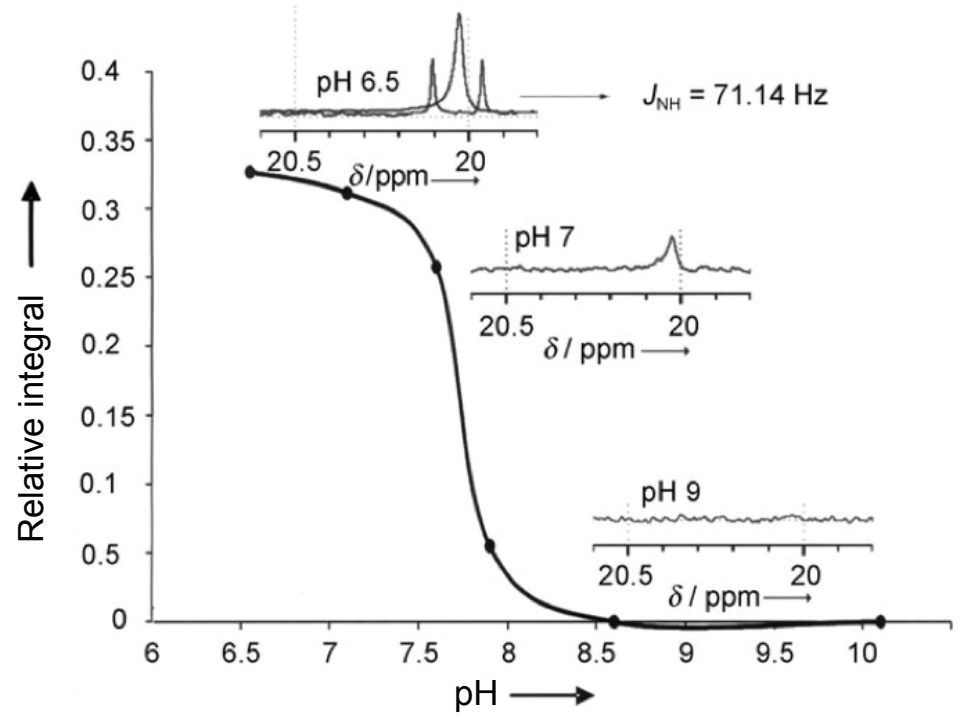

Figure 16. ${ }^{1} \mathrm{H} \mathrm{NMR}$ titration of $\left[\mathrm{Fe}(\mathrm{CN})_{5}(\mathrm{HNO})\right]^{3-}$, with $\mathrm{OH}^{-}$. Inset, top left: signal splitting upon ${ }^{15} \mathrm{~N}$ labeling of the $\mathrm{Fe}^{\mathrm{II}}$ (nitrosyl) moieties. From reference 106. 
Based on calibrated DFT calculations, Lehnert and colleagues have suggested that $\left[\mathrm{Fe}(\mathrm{CN})_{4}(\mathrm{NO})\right]^{3-}$, resulting from the fast trans-cyanide labilization from $\left[\mathrm{Fe}(\mathrm{CN})_{5}(\mathrm{NO})\right]^{4-}$ during the ongoing titration process (eq 39), might suffer a competitive protonation with free cyanide, eqs 40 and $41\left(\mathrm{p} K_{\mathrm{a}}(\mathrm{HCN})=9.2\right)$. Therefore, the 7.7 feature would correspond to the $\mathrm{p} K_{\mathrm{a}}$ of $\left[\mathrm{Fe}(\mathrm{CN})_{4}(\mathrm{HNO})\right]^{2-} \cdot[17]$

$$
\begin{aligned}
& {\left[\mathrm{Fe}(\mathrm{CN})_{5}(\mathrm{HNO})\right]^{3-} \rightleftarrows\left[\mathrm{Fe}(\mathrm{CN})_{5}(\mathrm{NO})\right]^{4-}+\mathrm{H}^{+} \quad \text { (38) } \quad K_{38} \quad \mathrm{p} K_{\mathrm{a} 38}=10-11 \text { ? }} \\
& {\left[\mathrm{Fe}(\mathrm{CN})_{5}(\mathrm{NO})\right]^{4-} \rightleftarrows\left[\mathrm{Fe}(\mathrm{CN})_{4}(\mathrm{NO})\right]^{3-}+\mathrm{CN}^{-} \quad \text { (39) } K_{39}} \\
& {\left[\mathrm{Fe}(\mathrm{CN})_{4}(\mathrm{NO})\right]^{3-}+\mathrm{H}^{+}===\left[\mathrm{Fe}(\mathrm{CN})_{4}(\mathrm{HNO})\right]^{2-} \quad(40) \quad K_{40}} \\
& \mathrm{CN}^{-}+\mathrm{H}^{+} \rightleftarrows \mathrm{HCN}
\end{aligned}
$$

The onset of the precedent equilibria along the addition of $\mathrm{OH}^{-}$and the consideration of available and estimated values of $K$ in reactions 38-41 allow proposing that $\left[\mathrm{Fe}(\mathrm{CN})_{5}(\mathrm{NO})\right]^{4-}$ is the dominant nitroxyl species at the end of titration $(\mathrm{pH}$ $10)$, with some equilibrated $\left[\mathrm{Fe}(\mathrm{CN})_{5}(\mathrm{HNO})\right]^{3-}$ and $\left[\mathrm{Fe}(\mathrm{CN})_{4}(\mathrm{NO})\right]^{3-}$. We might conclude that both the ${ }^{1} \mathrm{H}$ and ${ }^{17} \mathrm{O} \mathrm{NMR}$ evidence, as well as our results on the unchanged absorptivity of $\mathrm{I}_{445}$ in the $\mathrm{pH}$ range 6-10 [106] strongly support a new $\mathrm{p} K_{\mathrm{a}}$ estimation in the range $10-11$ for the $\left[\mathrm{Fe}(\mathrm{CN})_{5}(\mathrm{HNO})\right]^{3-} \rightarrow\left[\mathrm{Fe}^{\mathrm{II}}(\mathrm{CN})_{5}(\mathrm{NO})\right]^{4-}$ conversion.

In high contrast with $\left[\mathrm{Fe}(\mathrm{CN})_{5}(\mathrm{NO})\right]^{4-}$ (whose trans-cyanide labilization might be a few orders of magnitude stronger than for $\left[\mathrm{Fe}(\mathrm{CN})_{5}(\mathrm{NO})\right]^{3-}$, cf. $\left.K_{31}\right)$, the absence of trans-cyanide labilization in $\left[\mathrm{Fe}(\mathrm{CN})_{5}(\mathrm{HNO})\right]^{3-}$ becomes remarkable. It relates to the N-protonation, which decreases the $\sigma$-bonding of HNO toward the metal. Besides, cyanides are good $\sigma$-donors that enrich the electron density at $\mathrm{Fe}^{\mathrm{II}}$ and strengthen the $\pi$ bonding interaction with $\mathrm{HNO}$. The nearly equal axial and equatorial Fe-C distances calculated for $\left[\mathrm{Fe}(\mathrm{CN})_{5}(\mathrm{HNO})\right]^{3-},[46]$ and DFT calculations with other HNO-complexes[17] are consistent with experimental results on HNO being unable to activate sGC.[17,113]

The need for synthesizing other iron heme models for best disclosing the biorelevant properties of bound HNO has been elusive because of the putative instabilities of the used iron-porphyrin species toward disproportionation, as observed for $5 \mathrm{C} \mathrm{NO}^{-}$-complexes in non-aqueous solvents. By adding acetic acid to [Fe(3,5-Me-BAFP)(NO) $]^{-}$in THF, the UV-vis changes in the Soret bands were assigned to the binding of HNO in a 5C complex, which seems consistent.[102] Pellegrino and Doctorovich isolated the $\mathrm{n}=7$ sodium salt of [Fe(TPPS)(NO) $]^{4-}$, and observed the UV-vis changes upon one-electron reduction in aqueous medium.[114] By using CV methodologies described below, the dependence of $E_{\mathrm{NO}}$ ${ }_{\mathrm{H}+/ \mathrm{HNO}}$ on the $\mathrm{pH}$ led to a $\mathrm{p} K_{\mathrm{a}}$ of 9.7 for the supposed $5 \mathrm{C}[\mathrm{Fe}(\mathrm{TPPS})(\mathrm{HNO})]^{\mathrm{n}}$. The conclusion is also plausible, though the product might be a $6 \mathrm{C}$ species, probably with $\mathrm{OH}^{-}$or phosphate binding to the $5 \mathrm{C}$ intermediate.

\subsection{The influence of changing the coligands on the $\mathrm{pK}$ a of bound $\mathrm{HNO}$, correlated with changes in the redox potentials}

By expanding the experimental approach on the $\left[\mathrm{Ru}\left(\mathrm{Me}_{3}[9] \text { aneN } \mathrm{N}_{3}\right)(\mathrm{bpy})(\mathrm{NO})\right]^{3,2,1+}$ species that allowed determining the $\mathrm{p} K_{\mathrm{a}}$ of the HNO-bound one by using a potential/pH diagram,[38] Slep and coworkers made a significant synthetic progress by isolating three members of the $n=7$ series with $\mathrm{L}^{2}$ coligands of different donor abilities, namely $\left[\mathrm{Ru}\left(\mathrm{Me}_{3}[9] \mathrm{aneN}_{3}\right)\right.$ $($ bpy $)(\mathrm{NO})]^{2+}\left([1-\mathrm{NO}]^{2+}\right),\left[\mathrm{Ru}\left(\mathrm{Me}_{3}[9] \mathrm{aneN}_{3}\right)(\mathrm{MeObpy})(\mathrm{NO})\right]^{2+}\left([2-\mathrm{NO}]^{2+}\right)$ and $\left[\mathrm{Ru}\left(\mathrm{Me}_{3}[9] \mathrm{aneN}_{3}\right)(\mathrm{bpym})(\mathrm{NO})\right]^{2+}([3-$ $\mathrm{NO}^{2+}$ ).[39] In this way, reversible cyclic voltammograms (Figure 17) were obtained by dissolving the pure solids (very stable under anaerobic conditions) in acetonitrile solutions, and by oxidizing and reducing them, with corresponding one-electron waves giving the $n=6$ and $n=8$ species, respectively. Figure 18 discloses the UV-vis spectra starting with $[3-\mathrm{NO}]^{2+}$ in aqueous medium, obtained with spectroelectrochemical reductions complemented by controlled potential coulometry. The one-electron nature of the redox events was confirmed, and two distinct spectra emerged upon reduction in acid or alkaline solutions, at $\mathrm{pH} 2.5$ and 12.5. The latter situation corresponds to the actual $\{\mathrm{RuNO}\}^{7 / 8}$ one-electron conversion represented by eq 42, while the former involves a pH-dependent proton-coupled one-electron reduction, eq 43. By fitting the experimental data with an adequate Nernstian model, numerical values for both standard redox potentials can be obtained, as well as for $K_{a}$, the acidity constant of bound HNO.

$$
\begin{aligned}
& {\left[\mathrm{Ru}\left(\mathrm{Me}_{3}[9] \mathrm{aneN}_{3}\right)\left(\mathrm{L}^{2}\right)(\mathrm{NO})\right]^{2+}+\mathrm{e}^{-} \rightarrow\left[\mathrm{Ru}\left(\mathrm{Me}_{3}[9] \operatorname{aneN}_{3}\right)\left(\mathrm{L}^{2}\right)(\mathrm{NO})\right]^{+}} \\
& {\left[\mathrm{Ru}\left(\mathrm{Me}_{3}[9] \operatorname{aneN}_{3}\right)\left(\mathrm{L}^{2}\right)(\mathrm{NO})\right]^{2+}+\mathrm{e}^{-}+\mathrm{H}^{+} \rightarrow\left[\mathrm{Ru}\left(\mathrm{Me}_{3}[9] \operatorname{aneN}_{3}\right)\left(\mathrm{L}^{2}\right)(\mathrm{HNO})\right]^{2+}}
\end{aligned}
$$




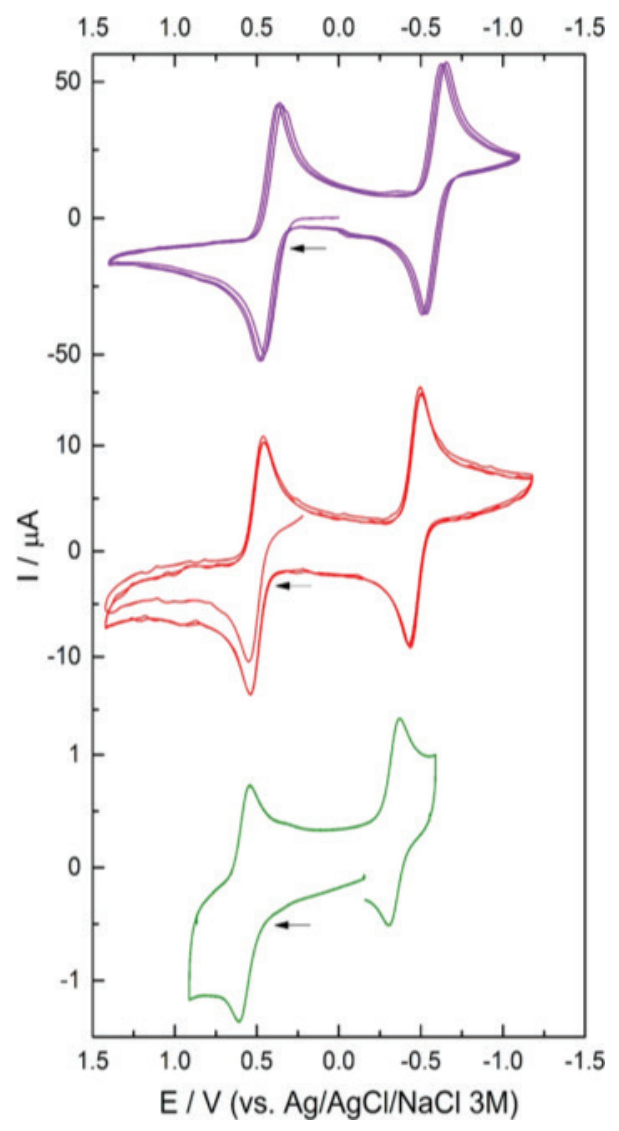

Figure 17. Cyclic Voltammograms obtained $\mathrm{f}$ / V vs. Ag/AgCl/NaCl 3M) olet), and [3-NO $]^{2+}$ (green) in dry CH${ }_{3} \mathrm{CN} /$ $\mathrm{Bu}_{4} \mathrm{NPF}_{6}(0.2 \mathrm{M})$ at $298 \mathrm{~K}$. Scan rate, $100 \mathrm{mV} \mathrm{s}^{-1}, E v s \mathrm{Ag} / \mathrm{AgCl} / \mathrm{NaCl}(3 \mathrm{M})$. From reference 39.

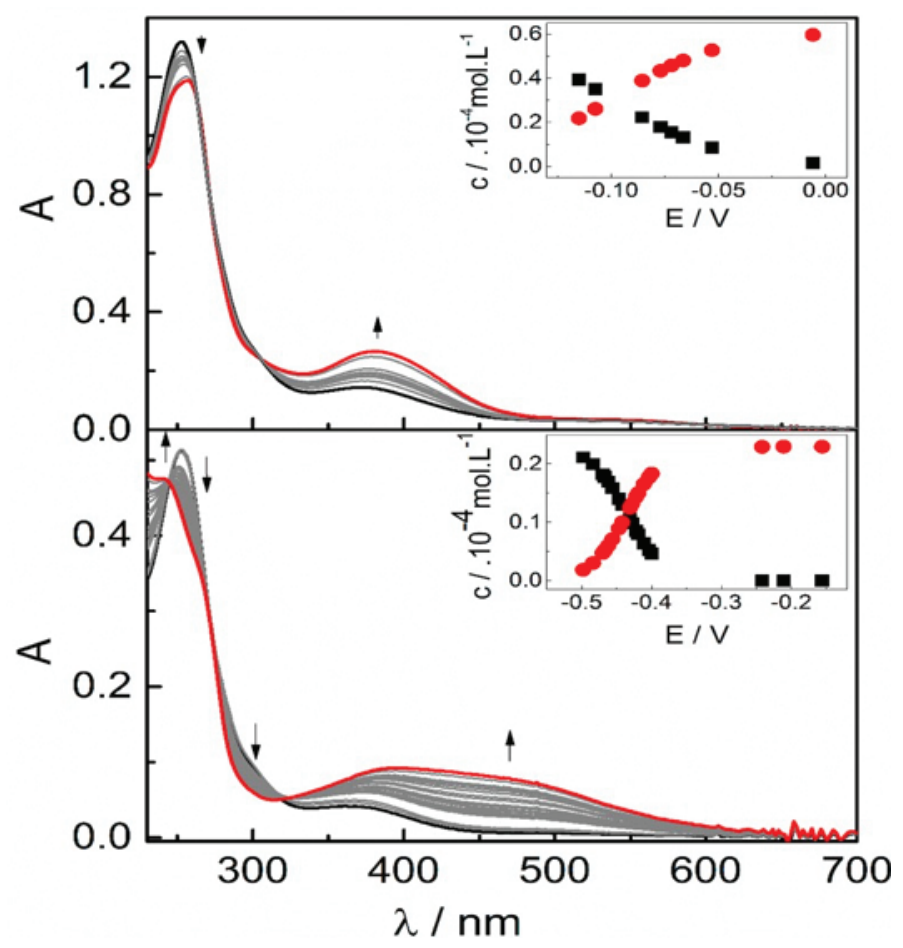

Figure 18. UV-vis spectra obtained by spectroelectro $\lambda / \mathrm{nm}$ of $[3-\mathrm{NO}]^{2+}$ in aqueous media $[I=1 \mathrm{M} \mathrm{NaCl}$ and $E$ vs $\mathrm{Ag} / \mathrm{AgCl} / \mathrm{NaCl}(3 \mathrm{M})]$ at $298 \mathrm{~K}$ under anaerobic conditions. The insets show the fraction of the different species as obtained from global analysis. Top: One-electron reduction at $\mathrm{pH} 2.5$ (phosphate buffer). Bottom: One-electron reduction at pH 12.5 (phosphate buffer). From reference 39. 
Figure 19 displays an overlap of Pourbaix diagrams, obtained for each of the three complexes, that allow visualizing the corresponding $\mathrm{p} K_{\mathrm{a}}$ 's of the HNO-complexes. The latter information is gathered in Table 7. The $E^{\circ}$ values for the redox couples $[\mathrm{RuNO}\}^{6 / 7}$ and $\{\mathrm{RuNO}\}^{7 / 8}$ behave similarly, with a remarkable decrease in the order $[3-\mathrm{NO}]^{2+}>[1-\mathrm{NO}]^{2+}>[2-$ $\mathrm{NO}]^{2+}$. The trends reflect the increasing donor properties of $\mathrm{L}^{2}$, as also described for the acetonitrile solution experiments. The most striking result is the impressive change in the $\mathrm{p} K$ alues of bound HNO spanning a range of three $\mathrm{pH}$ units triggered by relatively subtle modifications of $\mathrm{L}^{2}$, with virtually no detectable structural changes of the complexes. The linear correlation between $\mathrm{p} K_{\mathrm{a}}$ values and the reduction potential for the $[\mathrm{RuNO}\}^{6 / 7}$ and $\{\mathrm{RuNO}\}^{7 / 8}$ conversions is reasonable, as both are likewise affected by the electronic density modulation introduced by $\mathrm{L}^{2}$. These remarkable results highlight the bioinorganic relevance of allowing modulation of $\mathrm{HNO} / \mathrm{NO}^{-}$conversions in metallonitrosyl systems that might influence either the trans release and/or the reducing capabilities, based on the contrasting structural and redox properties of bound $\mathrm{HNO}$ vs $\mathrm{NO}^{-}$.

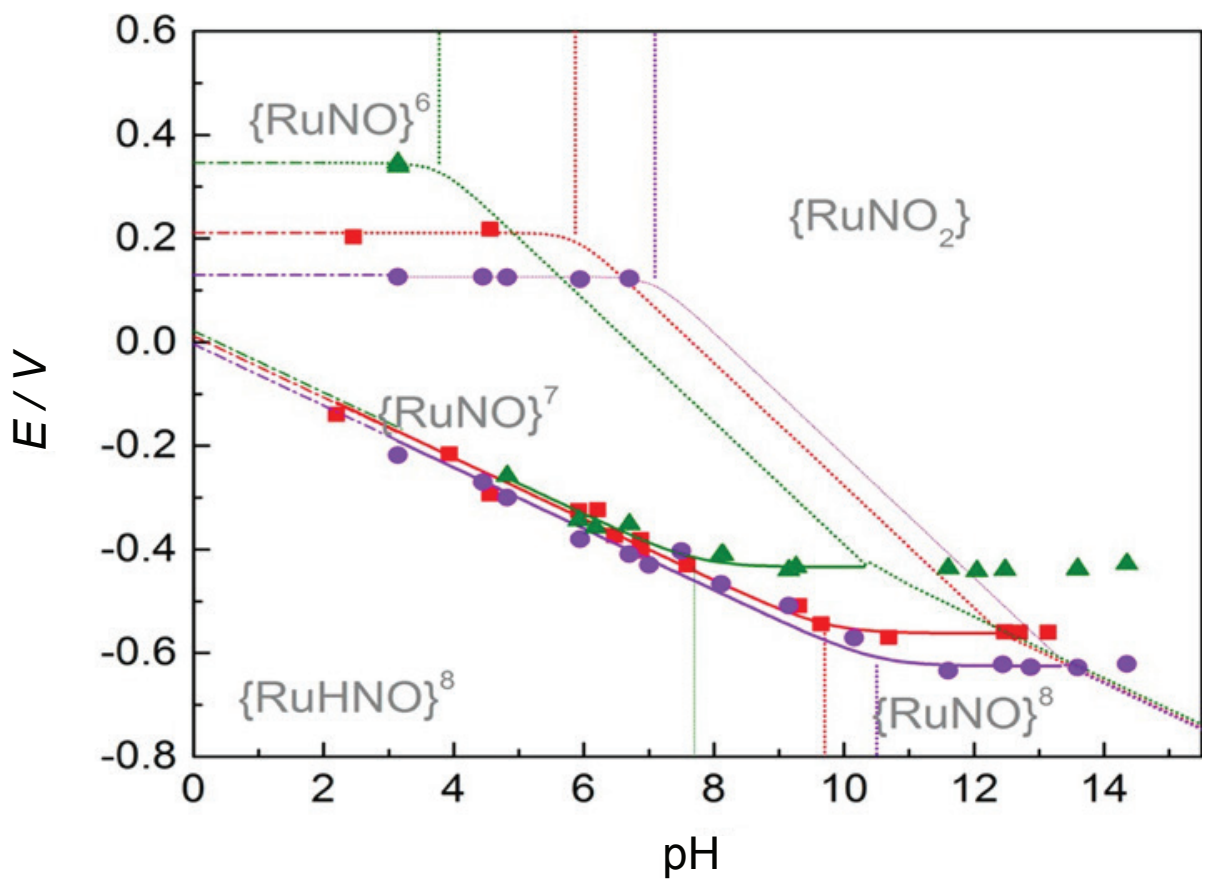

Figure 19. Comparison of the Pourbaix diagrams obtained for $[1-\mathrm{NO}]^{2+}$ (red), $[2-\mathrm{NO}]^{2+}$ (violet), and $[3-\mathrm{NO}]^{2+}$ (green), collected by CV/SWV/SEC in different buffer solutions $[I=1 \mathrm{M} \mathrm{NaCl}$, at $298 \mathrm{~K}, E$ vs $\mathrm{Ag} / \mathrm{AgCl} / \mathrm{NaCl}(3 \mathrm{M})]$. From reference 39 .

\begin{tabular}{|c|c|c|c|}
\hline \multicolumn{4}{|c|}{ Table 7. Reduction Potentials and $\mathrm{p} K_{\mathrm{a}}(\mathrm{HNO})$ Obtained from the Pourbaix Diagrams ${ }^{\mathrm{a}}$} \\
\hline & $E_{\text {KOHNo }} / \mathrm{V}$ & $E_{\mathrm{N} \text { ONO }}-\mathrm{V}$ & $\mathrm{p} K_{\mathrm{a} \text { HNo }}$ \\
\hline$[3-\mathrm{NO}]^{n+}$ & $0.021(5)$ & $-0.434(4)$ & $7.7(1)$ \\
\hline$[1-\mathrm{NO}]^{n+}$ & $0.011(9)$ & $-0.562(8)$ & $9.7(2)$ \\
\hline$[2-\mathrm{NO}]^{n+}$ & $-0.004(9)$ & $-0.625(8)$ & $10.5(2)$ \\
\hline
\end{tabular}

\subsection{The redox properties of bound HNO and NO-}

This issue is crucially relevant for biological systems and merits a detailed consideration. We found that $\left[\mathrm{Fe}(\mathrm{CN})_{5}(\mathrm{HNO})\right]^{3-}$ was unreactive at $\mathrm{pH} 6$ toward weak oxidants like methylviologen $\left(\mathrm{MV}^{2+}, E=-0.44 \mathrm{~V}\right)$ and nitroprusside $(E=0.05$ V). [107] By using the mild oxidant $\left[\mathrm{Fe}(\mathrm{CN})_{6}\right]^{3-}(E=0.4 \mathrm{~V})$, a slow reactivity of $\left[\mathrm{Fe}(\mathrm{CN})_{5}(\mathrm{HNO})\right]^{3-}$ through a second order rate law was observed for reaction (44), with $k_{44}=70 \mathrm{M}^{-1} \mathrm{~s}^{-1}$, much lower than the rate constants for $\left[\mathrm{Fe}(\mathrm{CN})_{6}\right]^{3-}$ reacting with other $\left[\mathrm{Fe}^{\mathrm{II}}(\mathrm{CN})_{5}(\mathrm{~L})\right]^{\mathrm{n}-}$ ions by metal-centered redox interchange $\left(k \sim 10^{5} \mathrm{M}^{-1} \mathrm{~s}^{-1}\right)$. The magnitude of $k_{44}$ is similar to that found for free $\mathrm{HNO}$ reacting with $\left.\left[\mathrm{Fe}(\mathrm{CN})_{6}\right)\right]^{3-}$, and also consistent with the redox potential estimated 
through the reversible one-electron wave found in the $\mathrm{CV}$ of $\left[\mathrm{Fe}(\mathrm{CN})_{5}(\mathrm{HNO})\right]^{3-}$ at $\mathrm{pH} 6\left(E_{1 / 2}=0.32 \mathrm{~V}\right)$, assigned to the $\left[\mathrm{Fe}(\mathrm{CN})_{5}(\mathrm{NO})\right]^{3-}, \mathrm{H}^{+} /\left[\mathrm{Fe}(\mathrm{CN})_{5}(\mathrm{HNO})\right]^{3-}$ redox couple.[107]

$$
\left.\left[\mathrm{Fe}(\mathrm{CN})_{5}(\mathrm{HNO})\right]^{3-}+2\left[\mathrm{Fe}(\mathrm{CN})_{6}\right)\right]^{3-} \rightarrow\left[\mathrm{Fe}(\mathrm{CN})_{5}(\mathrm{NO})\right]^{2-}+\mathrm{H}^{+}+2\left[\mathrm{Fe}(\mathrm{CN})_{6}\right]^{4-}
$$

A mechanistic analysis in terms of Marcus cross-reaction predictions suggests a NO-centered proton-coupled PCET route for reaction (44), associated with a high reorganization energy. The latter results put into question the claimed high reducing power of $\mathrm{HNO}$, either free or bound to metal centers (cf. eq $5, \sim-0.5 \mathrm{~V}$ at $\mathrm{pH}$ 7).[7]

In remarkable contrast, the results at $\mathrm{pH} 10$ with the same weak oxidants led to immediate production of the viologen radical, reaction (45), as well as to a quantitative formation of the comproportionation product, $\left[\mathrm{Fe}(\mathrm{CN})_{5}(\mathrm{NO})\right]^{3-}$, reaction (46).[107] The latter reaction explains the striking red $\rightarrow$ orange color changes upon stirring during the initial onset of dithionite titration, see above 6.1. This is confirmatory evidence of emerging deprotonation of bound $\mathrm{HNO}$ at $\mathrm{pH} 10$, and consequently a much higher reducing power of bound $\mathrm{NO}^{-}$compared to $\mathrm{HNO}$.

$$
\begin{aligned}
& {\left[\mathrm{Fe}(\mathrm{CN})_{5}(\mathrm{HNO})\right]^{3-}+\mathrm{MV}^{2+}+\mathrm{OH}^{-} \rightarrow\left[\mathrm{Fe}(\mathrm{CN})_{5}(\mathrm{NO})\right]^{3-}+\mathrm{MV}^{+}+\mathrm{H}_{2} \mathrm{O}} \\
& {\left[\mathrm{Fe}(\mathrm{CN})_{5}(\mathrm{HNO})\right]^{3-}+\left[\mathrm{Fe}(\mathrm{CN})_{5}(\mathrm{NO})\right]^{2-}+\mathrm{OH}^{-} \rightarrow 2\left[\mathrm{Fe}(\mathrm{CN})_{5}(\mathrm{NO})\right]^{3-}+\mathrm{H}_{2} \mathrm{O}}
\end{aligned}
$$

It can be concluded that the nitroxyl-binding chemical properties are regulated by the $\mathrm{pH}$ and redox state of the environment. As demonstrated for the non-heme systems, iron-heme proteins could afford such a regulatory mission on demand, by an appropriate use of ligands (either in axial or equatorial positions), as well as by a controlled location of either external electric fields or specific H-bonding interactions with backbone residues close to the reactive sites.

\section{Conclusions}

A comprehensive picture of the structure and reactivity of nitric oxide (NO) and redox derivatives $\left(\mathrm{NO}^{+}, \mathrm{NO}^{-} / \mathrm{HNO}^{2}\right.$ $\mathrm{NO}_{\mathrm{x}}$ ) has been presented, focusing on the coordination chemistry in transition metal centers, mainly iron and ruthenium. Though the properties can be roughly described by the total electron content in the frontier metal/ $\pi^{*}{ }_{\text {NO }}$ orbitals, a deeper insight has been provided that takes into account the influence of the axial and/or equatorial coligands, as well as the second-sphere interactions, for controlling the $\sigma-\pi$ interactions and the actual atomic electronic distributions. Different reactivity modes of the M-N-O groups, mainly ligand formation/dissociations, electrophilic and nucleophilic additions, disproportionations, acid-base and redox reactions have been addressed in a biologically relevant context, by using an adequate model approach that combines the structural, spectroscopic, and theoretical information most relevant for understanding the enzyme functions. New results on the chemical interactions with $\mathrm{O}_{2}$ and other gasotransmitters like $\mathrm{H}_{2} \mathrm{~S}$ point to new developments in the field of biological signaling.

\section{Acknowledgements}

To my coworking colleagues and students at INQUIMAE, in the "end of the world" and not so in the end, as reported in the citations, that have sustained and enriched our scientific approach. Support from CONICET, the University of Buenos Aires and the Volkswagen Foundation are gratefully acknowledged.

\section{References}

[1] Bianco, C. L.; Toscano, J. P.; Fukuto, J. M. An Integrated View of the Chemical Biology of NO, CO, $\mathrm{H}_{2} \mathrm{~S}$, and $\mathrm{O}_{2}$. In Nitric Oxide, Elsevier Inc., 2017, Chapter 2, pp. 9-21.

[2] Kevil, C.; Cortese-Krott, M. M.; Nagy, P.; Papapetropoulos, A.; Feelisch, M. Szabo, C. Cooperative Interactions Between $\mathrm{NO}$ and $\mathrm{H}_{2} \mathrm{~S}$ : Chemistry, Biology, Physiology, Pathophysiology. In Nitric Oxide, Elsevier Inc., 2017, Chapter 5 , pp. 83-85.

[3] Ignarro, L. J. Nitric Oxide is not just blowing in the wind. Brit. J. Pharmacol. 2019, 176, 131-146.

[4] Yu, M.; Lamattina, L.; Spoel, S. H.; Loake, G. J. Nitric Oxide function in plant biology: a redox cue in deconvolution. New Phytol. 2014, 202, 1142-1156.

[5] Feelisch, M.; Stamler, J. S., Eds. Methods in Nitric Oxide Research, J. Wiley \& Sons: Chichester, 1996. 
[6] Goodrich, L. E.; Paulat, F.; Praneeth, V. K. K.; Lehnert, N. Electronic Structure of Heme-Nitrosyls and its Significance for Nitric Oxide Reactivity, Sensing, Transport and Toxicity in Biological Systems. Inorg. Chem. 2010, 49, $6293-6316$.

[7] Ford, P.C.; Miranda, K. M. The Solution Chemistry of Nitric Oxide and Other Reactive Nitrogen Species. Nitric Oxide, 2020, 103, 31-46.

[8] Cortese-Krott, M.; Koning, A.; Kühnle, G.; Nagy, P.; Bianco, C.; Pasch, A.; Wink, D.; Fukuto, J.; Jackson, A.; van Goor, H.; Olson, K.; Feelisch, M. The Reactive Species Interactome: Evolutionary Emergence, Biological Significance, and Opportunities for Redox Metabolomics and Personalized Medicine. Antioxid. Redox Signaling. 2017, 27, 684-712.

[9] Broniowska, K. A.; Hogg, N. The Chemical Biology of S-Nitrosothiols. Antioxid. Redox Signaling. 2012, 17, $969-980$.

[10] Lehnert, N.; Berto, T. C.; Galinato, M. G. I.; Goodrich, L. E. The Role of Heme-Nitrosyls in the Biosynthesis, Transport, Sensing, and Detoxification of Nitric Oxide (NO) in Biological Systems: Enzymes and Model Complexes. In Handbook of Porphyrin Science; World Scientific: NJ, 2011, 14, 1-247 (Chapter 263).

[11] Olabe, J. A. The coordination chemistry of nitrosyl in cyanoferrates. An exhibit of bioinorganic relevant reactions. Dalton Trans. 2008, 3633-3648.

[12] Bari, S. E.; Olabe, J. A.; Slep, L. D. Three Redox States of Metallonitrosyls in Aqueous Solution. Adv. Inorg. Chem. 2015, 67, 87-144.

[13] Marcolongo, J. P.; Zeida, A.; Slep, L. D.; Olabe, J. A. Thionitrous Acid/Thionitrite and Perthionitrite Intermediates in the "Crosstalk" of $\mathrm{NO}$ and $\mathrm{H}_{2} \mathrm{~S}$. Adv. Inorg. Chem. 2017, 70, 277-309.

[14] Stanbury, D. M. Reactivity of Inorganic Radicals in Aqueous Solution. In Physical Inorganic Chemistry, Reactions, Processes, and Applications, Bakac, A. Ed., Wiley, 2010, Chapter 9, pp 395-427.

[15] Goldstein, S.; Czapski, G. Kinetics of Nitric Oxide Autoxidation in Aqueous Solution in the Absence and Presence of Various Reductants. The Nature of the Oxidizing Intermediates. J. Am. Chem. Soc. 1995, 117, 12078-12084.

[16] Fukuto, J. A recent history of nitroxyl chemistry, pharmacology, and therapeutic potential. Brit. J. Pharmacol. 2019, $176,135-146$.

[17] Doctorovich, F.; Farmer, P. J.; Martí, M. M. Eds. The Chemistry and Biology of Nitroxyl (HNO), Elsevier Inc. 2017.

[18] Poskrebyshev, G. A.; Shafirovich, V.; Lymar, S. V. Disproportionation Pathways of Aqueous Hyponitrite Radicals



[19] Bringas, M.; Semelak, J.; Estrin, D. A. Theoretical investigation of the mechanism of the nitroxyl decomposition in aqueous solution. J. Inorg. Biochem. 2016, 162, 102-108.

[20] Wright, A. M.; Hayton, T. W. Understanding the Role of Hyponitrite in Nitric Oxide Reduction. Inorg. Chem. 2015, $54,9330-9341$.

[21] Speelman, A. L.; Lehnert, N. Heme versus Non-Heme Iron-Nitroxyl $\{\mathrm{FeN}(\mathrm{H}) \mathrm{O}\}^{8}$ Complexes: Electronic Structure and Biologically Relevant Reactivity. Acc. Chem. Res. 2014, 47, 1106-1116.

[22] Suárez, S. A.; Neuman, N. I.; Muñoz, M.; Alvarez, L.; Bikiel, D.E.; Brondino, C. D.; Ivanovic-Burmazovic, I.; Miljkovic, J. L.; Filipovic, M. R.; Martí, M. A.; Doctorovich, F. Nitric Oxide Is Reduced to HNO by Proton-Coupled Nucleophilic Attack by Ascorbate, Tyrosine, and Other Alcohols. A New Route to HNO in Biological Media? J. Am. Chem. Soc. 2015, 137, 4720-4727.

[23] Suárez, S. A.; Muñoz, M.; Alvarez, L.; Venancio, M. F.; Rocha, W. R.; Bikiel, D. E.; Martí, M. A.; Doctorovich, F. HNO Is Produced by the Reaction of NO with Thiols. J. Am. Chem. Soc. 2017, 139, 14483-14487.

[24] Venancio, M. F.; Doctorovich, F.; Rocha, W. R. Solvation and Proton-Coupled Electron Transfer Reduction Potential of ${ }^{2} \mathrm{NO}$ to ${ }^{1} \mathrm{HNO}$ in Aqueous Solution: A Theoretical Investigation. J. Phys. Chem. B 2017, 121, 6618-6625.

[25] Enemark, J. H.; Feltham, R. D. Principles of structure, bonding and reactivity for metal nitrosyl complexes. Coord. Chem. Rev. 1974, 13, 339-406.

[26] McCleverty, J. A. Chemistry of Nitric Oxide Relevant to Biology. Chem. Rev. 2004, 104, 403-418. 
[27] Olabe, J. A. Chemistry of Bound Nitrogen Monoxide and Related Redox Species. In Physical Inorganic Chemistry, Reactions, Processes, and Applications, Bakac, A. Ed., Wiley, 2010, Chapter 7, pp 281-337.

[28] Carducci, M. D.; Pressprich, M. R.; Coppens, P. Diffraction Studies of Photoexcited Crystals: Metastable NitrosylLinkage Isomers of Sodium Nitroprusside. J. Am. Chem. Soc. 1997, 119, 2669-2678.

[29] Chacón Villalba, M. E.; Güida, J. A.; Varetti, E. L.; Aymonino, P. J. The Structure of the FeNO Group in Two Metastable States (MS1 and MS2) of the Nitroprusside Anion in $\mathrm{Na}_{2}\left[\mathrm{Fe}(\mathrm{CN})_{5} \mathrm{NO}\right] \cdot 2 \mathrm{H}_{2} \mathrm{O}$. Infrared Spectra and Quantum Chemistry Calculations for the Normal and the ${ }^{15} \mathrm{NO}$ and $\mathrm{N}^{18} \mathrm{O}$ Isotopic Substituted Substance. Inorg. Chem. 2003, 42, 2622-2627.

[30] García Serres, R.; Grapperhaus, C. A.; Bothe, E.; Bill, E.; Weyhermüller, T.; Neese, F.; Wieghardt, K. Structural, Spectroscopic, and Computational Study of an Octahedral, Non-Heme $\{\text { FeNO }\}^{6-8}$ Series: $[\mathrm{Fe}(\mathrm{NO})(\mathrm{cyclam}-\mathrm{ac})]^{+2,+1,0}$. J. Am. Chem. Soc. 2004, 126, 5138-5153.

[31] Immoos, C. E.; Sulc, F. J.; Farmer, P. J.; Czarnecki, K.; Bocian, D.; Levina, A.; Aitken, J. B.; Armstrong, R.; Lay, P. A. Bonding in HNO-Myoglobin as Characterized by X-ray Absorption and Resonance Raman Spectroscopies. J. Am. Chem. Soc. 2005, 127, 814-815.

[32] Praneeth, V. K. K.; Paulat, F.; Berto, T. C.; DeBeer George, S.; Nather, C.; Sulok, C. D.; Lehnert, N. Electronic Structure of Six-Coordinate Iron(III)-Porphyrin Adducts: The Elusive Iron(III)-NO(radical) State and Its Influence on the Properties of These Complexes. J. Am. Chem. Soc. 2008, 130, 15288-15303.

[33] McQuarters, A. B.; Kampf, J. W.; Alp, E. E.; Hu, M.; Zhao, J.; Lehnert, N. Ferric Heme-Nitrosyl Complexes: Kinetically Robust or Unstable Intermediates? Inorg. Chem. 2017, 56, 10513-10528.

[34] Xu, N.; Goodrich, L. E.; Lehnert, N.; Powell, D. R.; Richter-Addo, G. B. Preparation of the Elusive [(por)Fe(NO) (O-ligand)] Complex by Diffusion of Nitric Oxide into a Crystal of the Precursor. Angew. Chem. Int. Ed. 2013, 52, 3896-3900.

[35] Xu, N.; Powell, D. R.; Cheng, L.; Richter-Addo, G. B. The first structurally characterized nitrosyl heme thiolate. Chem. Commun. 2006, 2030-2032.

[36] Hunt, A. P.; Lehnert, N. The Thiolate Trans Effect in Heme $\{\mathrm{FeNO}\}{ }^{6}$ Complexes and Beyond: Insight into the Nature of the Push Effect. Inorg. Chem. 2019, 58, 17, 11317-11332.

[37] Shimizu, H.; Obayashi, E.; Gomi, Y.; Arakawat, S.; Park, Y.; Nakamura, S.; Adachi, I.; Shoun, H.; Shiro, Y. Proton delivery in NO reduction by fungal nitric-oxide reductase: Cryogenic crystallography, spectroscopy, and kinetics of ferric-NO complexes of wild-type and mutant enzymes. J. Biol. Chem. 2000, 275, 4816-4825.

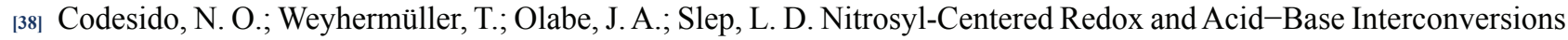
in $\left[\mathrm{Ru}\left(\mathrm{Me}_{3}[9] \mathrm{aneN}_{3}\right)(\text { bpy })(\mathrm{NO})\right]^{3,2,1+}$. The $\mathrm{p} K_{\mathrm{a}}$ of HNO for its Nitroxyl Derivative in Aqueous Solution. Inorg. Chem. 2014, 53, 981-997.

[39] Levin, N.; Codesido, N. O.; Marcolongo, J. P.; Alborés, P.; Weyhermüller, T.; Olabe, J. A.; Slep, L. D. Remarkable Changes of the Acidity of Bound Nitroxyl (HNO) in the $\left[\mathrm{Ru}\left(\mathrm{Me}_{3}[9] \mathrm{aneN}_{3}\right)\left(\mathrm{L}^{2}\right)(\mathrm{NO})\right]^{\mathrm{n}+}$ Family $(\mathrm{n}=1-3)$. Systematic Structural and Chemical Exploration and Bioinorganic Chemistry Implications. Inorg. Chem. 2018, 57, 12270-12281.

[40] Ford, P. C.; Melo Pereira, J. C.; Miranda, K. M. Mechanisms of nitric oxide reactions mediated by biologically relevant metal centers. Struct. Bond. 2014, 154, 99-136.

[41] Franke, A.; Roncaroli, F.; van Eldik, R. Mechanistic Studies on the Activation of NO by Iron and Cobalt Complexes. Eur. J. Inorg. Chem. 2007, 773-798.

[42] Roncaroli, F.; Olabe, J. A.; van Eldik, R. Kinetics and Mechanism of the Formation of Nitroprusside from Aquapentacyanoferrate(III) and NO: Complex-Formation is Controlled by Outer-Sphere Electron Transfer. Inorg. Chem. 2002, 41, 5417-5425.

[43] Roncaroli, F.; Olabe, J. A.; van Eldik, R. Kinetics and Mechanism of the Interaction of Nitric Oxide with Pentacyanoferrate(II). Formation and Dissociation of $\left[\mathrm{Fe}(\mathrm{CN})_{5} \mathrm{NO}\right]^{3-}$. Inorg. Chem. 2003, 42, 4179-4189. 
[44] Speelman, A. L.; Zhang, B.; Krebs, C.; Lehnert, N. Structural and Spectroscopic Characterization of a High-Spin $\{\text { FeNO }\}^{6}$ Complex with an Iron(IV)-NO- Electronic Structure. Angew. Chem. Int. Ed. 2016, 55, 6685-6688.

[45] Wyllie, G. R. A.; Scheidt, W. R. Solid-State Structures of Metalloporphyrin NO xompounds Chem. Rev. 2002, 102, 1067-1089.

[46] Estrin, D. A.; Baraldo, L. M.; Slep, L. D.; Barja, B. C.; Olabe, J.A.; Paglieri, L.; Corongiu, G. Theoretical and Experimental Study of Medium Effects on the Structure and Spectroscopy of the $\left[\mathrm{Fe}(\mathrm{CN})_{5} \mathrm{NO}\right]^{2-}$ Ion. Inorg. Chem. 1996, 35, 3897-3903.

[47] Bezerra, C. W. B.; da Silva, S. C.; Gambardella, M. T. P.; Santos, R. H. A.; Plicas, L. M. A.; Tfouni, E.; Franco, D. W. Water $\pi$-Donation in trans-Tetrammineruthenium(II): Effect on Coordinated Water Properties Induced by a Trans NO Ligand. Inorg. Chem. 1999, 38, 5660-5667.

[48] Manoharan, P. T.; Gray, H. B. Electronic Structures of Metal Pentacyanonitrosyls. Inorg. Chem. 1966, 6, 823-839.

[49] González Lebrero,_M. C.; Scherlis, D. A.; Estiú, G. L.; Olabe, J. A.; Estrin, D. A. Theoretical Investigation of the Electronic Structure of Pentacyano(L)ferrate(II) Complexes with $\mathrm{NO}^{+}, \mathrm{NO}$ and $\mathrm{NO}^{-}$Ligands. Redox Interconversion, Protonation and Cyanide-Releasing Reactions. Inorg. Chem. 2001, 40, 4127-4133.

[50] Roncaroli, F.; Ruggiero, M. E.; Franco, D. W.; Estiú, G. L.; Olabe, J. A. Kinetic, Mechanistic, and DFT Study of the Electrophylic Reactions of Nitrosyl Complexes with Hydroxide. Inorg. Chem. 2002, 41, 5760-5769.

[51] Olabe, J. A.; Estiú, G. L. Theoretical Characterization of Stable $\eta^{1}-\mathrm{N}_{2} \mathrm{O}, \eta^{2}-\mathrm{N}_{2} \mathrm{O}, \eta^{1}-\mathrm{N}_{2}$, and $\eta^{2}-\mathrm{N}_{2}$ Bound-Species. Intermediates in the Addition Reactions of Nitrogen Hydrides with the Pentacyanonitrosylferrate(II) Ion. Inorg. Chem. 2003, 42, 4873-4880.

[52] Morando, P. J.; Borghi, E. B.; Schteingart, L. M.; Blesa, M. A. The Reaction of Cysteine with the Pentacyanonitrosylferrate(II) Ion. J. Chem. Soc. Dalton Trans. 1981, 435-440.

[53] Johnson, M. D.; Wilkins, R. G. Kinetics of the primary interaction of pentacyanonitrosylferrate(2-) (nitroprusside) with aliphatic thiols. Inorg. Chem. 1984, 23, 231-235.

[54] Roncaroli, F.; Olabe, J. A. The Reactions of Nitrosyl Complexes with Cysteine. Inorg. Chem. 2005, 44, 4719-4727.

[55] Quiroga, S. L.; Almaraz, A. E.; Amorebieta, V. T.; Perissinotti, L. L.; Olabe, J. A. Addition and Redox Reactivity of Hydrogen Sulfides $\left(\mathrm{H}_{2} \mathrm{~S} / \mathrm{HS}^{-}\right)$with Nitroprusside: New Chemistry of Nitrososulfide Ligands. Chem. Eur. J. 2011, 17, 4145-4146.

[56] Roncaroli, F.; Videla, M.; Slep, L. D.; Olabe, J. A. New features in the redox coordination chemistry of metal nitrosyls $\left\{\mathrm{M}-N O^{+}\right.$; M-NO; M-NO$\left.{ }^{-}(\mathrm{HNO})\right\}$, Coord. Chem. Rev. 2007, 251, 1903-1930.

[57] Doctorovich F.; Trapani, C. The reaction of pentacyanonitrosylferrate(II) with primary amines as a source of stabilized aliphatic diazonium ions: a new route to secondary amines. Tetrahedron Letters, 1999, 40, 4635-4638.

[58] Doctorovich, F.; Escola, N.; Trapani, C.; Estrin, D. A.; Turjanski, A. G.; González Lebrero, M. C.; Stabilization of Aliphatic and Aromatic Diazonium Ions by Coordination: An Experimental and Theoretical Study. Organometallics 2000, 19, 3810-3817.

[59] Doctorovich, F.; Granara, M.; Di Salvo, F. The reaction of $\left[\mathrm{Ru}(\mathrm{bpy})_{2}(\mathrm{NO}) \mathrm{Cl}\right]^{2+}$ and $\left[\mathrm{Fe}(\mathrm{CN})_{5} \mathrm{NO}\right]^{2-}$ with benzylamine: coordinated nitrosyl as an oxidizing agent. Transition Met. Chem. 2001, 26, 505-509.

[60] Doctorovich, F.; Di Salvo, F. Performing Organic Chemistry with Inorganic Compounds: Electrophilic Reactivity of Selected Nitrosyl Complexes. Acc. Chem. Res. 2007, 40, 985-993.

[61] Gutiérrez, M. M.;Amorebieta, V.T.; Estiú, G. L.; Olabe J.A. The Electrophylic Reactions ofPentacyanonitrosylferrate(II) with Hydrazine and Substituted Derivatives. Catalitic Reduction of Nitrite and Theoretical Prediction of $\eta^{1}-, \eta^{2}-\mathrm{N}_{2} \mathrm{O}$ Bound Intermediates. J. Am. Chem. Soc. 2002, 124, 10307-10319.

[62] Bykov, D.; Neese, F. Six-Electron Reduction of Nitrite to Ammonia by Cytochrome c Nitrite Reductase. Insights from Density Functional Theory Studies. Inorg. Chem. 2015, 54, 9303-9316. 
[63] Alluisetti, G. E.; Almaraz, A. E.; Amorebieta, V. T.; Doctorovich, F.; Olabe, J. A. Metal-Catalyzed Anaerobic Disproportionation of Hydroxylamine: Role of Diazene and Nitroxyl Intermediates in the Formation of $\mathrm{N}_{2}, \mathrm{~N}_{2} \mathrm{O}, \mathrm{NO}^{+}$, and $\mathrm{NH}_{3}$. J. Am. Chem. Soc. 2004, 126 13432-13442.

[64] Bari, S. E.; Amorebieta, V. T.; Gutierrez, M. M.; Olabe, J. A.; Doctorovich, F. J. Disproportionation of hydroxylamine by water-soluble iron(III) porphyrinate compounds. J. Inorg. Biochem. 2010, 104, 30-36.

[65] Gutiérrez, M. M.; Alluisetti, G. E.; Gaviglio, C.; Doctorovich, F.; Olabe, F. D.; Amorebieta, V. T. Catalytic disproportionation of N-alkylhydroxylamines bound to pentacyanoferrates. Dalton Trans. 2009, 1187-1194.

[66] Gutiérrez, M. M.; Olabe, J. A.; Amorebieta, V. T. Disproportionation of $O$-Methylhydroxylamine Catalyzed by Aquapentacyanoferrate(II). Inorg. Chem. 2011, 50, 8817-8825.

[67] Filipovic, M. R.; Eberhardt, M.; Prokopovic, V.; Mijuskovic, A.;Orescanin-Dusic, Z.; Reeh, P.; Ivanovic-Burmazovic, I. Beyond $\mathrm{H}_{2} \mathrm{~S}$ and NO Interplay: Hydrogen Sulfide and Nitroprusside React Directly to Give Nitroxyl (HNO). A New Pharmacological Source of HNO. J. Med. Chem. 2013, 56, 1499-1508.

${ }_{[68]}$ Gao, Y.; Toubaei, A.; Kong, X.; Wu, G. Solving the 170-Year-Old Mystery about Red-Violet and Blue Transient Intermediates in the Gmelin Reaction. Chem. Eur. J. 2015, 21, 1-7.

[69] Cortese-Krott, M. M.; Butler, A.; Woolins, J. D.; Feelisch, M. Inorganic sulfur-nitrogen compounds: from gunpowder chemistry to the forefront of biological signaling. Dalton Trans. 2016, 45, 5908-5919.

[70] Marcolongo, J. P.; Morzan, U. N.; Zeida, A.; Scherlis, D. A.; Olabe, J. A. Nitrosodisulfide [S,NO]- (perthionitrite) is a true intermediate during the "cross-talk" of nitrosyl and sulphide. Phys. Chem. Chem. Phys. 2016, 18, 30047-30052.

[71] Ivanovic-Burmazovic, I.; Filipovic, M. R. Saying NO to $\mathrm{H}_{2} \mathrm{~S}$ : A Story of HNO, HSNO, and SSNO-. Inorg. Chem. 2019, 58, 4039-4051.

[72] Marcolongo, J. P.; Venancio, M. F.; Rocha, W. R.; Doctorovich, F.; Olabe, J. A. NO/H $\mathrm{H}_{2} \mathrm{~S}$ “Crosstalk” Reactions. The Role of Thionitrites $\left(\mathrm{SNO}^{-}\right)$and Perthionitrites (SSNO$\left.{ }^{-}\right)$. Inorg. Chem. 2019, 58, 14981-4997.

[73] Hunt, A. P.; Lehnert, N. Heme-Nitrosyls: Electronic Structure Implications for Function in Biology. Acc. Chem. Res. 2015, 48, 2117-2125.

[74] Berto, T. C.; Speelman, A. L.; Zheng, S.; Lehnert, N. Mono- and dinuclear non-heme iron-nitrosyl complexes: Models for key intermediates in bacterial nitric oxide reductases. Coord. Chem. Rev. 2013, 257, 244-259.

[75] Lehnert, N.; Scheidt, W. R.; Wolf, M. W. Structure and Bonding in Heme-Nitrosyl Complexes and Implications for Biology. Struct. Bond. 2014, 154, 155-224.

[76] Nast, R.; Schmidt, J. Cyanonitrosylferrate und Cyanocarbonylnitrosyl-ferrate niedriger Oxydationsstuffen. Z. anorg. Allg. Chem. 1976, 421, 15-23.

[77] Lehnert, N.; Sage, J. T.; Silvernail, N.; Scheidt, W. R.; Alp. E. E.; Sturhahn, W.; Zhao, J. Oriented Single-Crystal Nuclear Resonance Vibrational Spectroscopy of [Fe(TPP)(MI)(NO)]: Quantitative Assessment of the trans Effect of NO. Inorg. Chem. 2010, 49, 7197-7215.

[78] Schmidt, J.; Kühr, H.; Dorn, W. L.; Kopf, J. Nitrosyl-Tetracyano-Ferrat(I). Inorg. Nucl. Chem. Lett. 1974, 10 , 55-61.

[79] Silvernail, N. J.; Olmstead, M. M.; Noll, B. C.; Scheidt, W. R. Tetragonal to Triclinic-A Phase Change for [Fe(TPP) (NO)]. Inorg. Chem. 2009, 48, 971-977.

[80] Bohle, D. S.; Hung, C. H. Ligand Promoted Rapid Dissociations from Ferrous Porphyrin Nitrosyls. J. Am. Chem. Soc. 1995, 117, 9584-9585.

[81] Pellegrino, J.; Bari, S. E.; Bikiel, D. E.; Doctorovich. Successful Stabilization of the Elusive Species $\{\text { FeNO }\}^{8}$ in a Heme Model. J. Am. Chem. Soc. 2010, 132, 989-995.

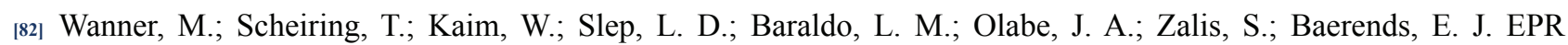
Characteristics of the $\left[(\mathrm{NC})_{5} \mathrm{M}(\mathrm{NO})\right]^{3-}$ Ions $(\mathrm{M}=\mathrm{Fe}, \mathrm{Ru}, \mathrm{Os})$. An Experimental and DFT Study Establishing NO as a Ligand. Inorg. Chem. 2001, 40, 5704-5707. 
[83] Frantz, S.; Sarkar, B.; Sieger, M.; Kaim, W.; Roncaroli, F.; Olabe, J. A.; Zalis, S. EPR Insensitivity of the MetalNitrosyl Spin-Bearing Moiety in Complexes [L $\left.\mathrm{Ru}^{\mathrm{II}}-\mathrm{NO}\right]^{\mathrm{k}}$. Eur. J. Inorg. Chem. 2004, 2902-2907.

[84] Singh, P.; Das, A. K.; Sarkar, B.; Niemeyer, M.; Roncaroli, F.; Olabe, J.A.; Fiedler, J.;Zalis, S.; Kaim, W. Redox Properties of Ruthenium Nitrosyl Porphyrin Complexes with Different Axial Ligation: Structural, Spectroelectrochemical (IR, UV-VIS-NIR, ESR) and Theoretical Studies. Inorg. Chem. 2008, 47, 7106-7113.

[85] Praneeth, W. W. W.; Nather, C.; Peters, G.; Lehnert, N. Spectroscopic Propoerties and Electronic Structure of Fiveand Six-Coordinate Iron(II) Porphyrin NO Complexes: Effect of the Axial N-Donor Ligand. Inorg. Chem. 2006, 45, $2795-2811$.

[86] Cheney, R. P.; Simic, M. G.; Hoffman, M. Z.; Taub, I. A.; Asmus, K. D. One-Electron Reduction of Pentacyanonitrosylferrate(II) Ion in Aqueous Solution. Inorg. Chem. 1997, 16, 2187-2192.

[87] Schwane, J. D.; Ashby, M. T. FTIR Investigation of the Intermediates Formed in the Reaction of Nitroprusside with Thiolates. J. Am Chem. Soc. 2002, 124, 6822-6823.

[88] Derbyshire, E. R.; Marletta, M. A. Structure and Regulation of Soluble Guanylate Cyclase. Annu. Rev. Biochem. 2012, 81, 533-559.

[89] Guo, Y.; Suess, D. L.; Herzik Jr., M. A.; Iavarone, A. T.; Britt, R. D.; Marletta, M. A. Nature Chemical Biology, 2017, $13,1216-1221$.

[90] Guo Y.; Marletta, M. A. Structural Insight into H-NOX Gas Sensing and Cognate Signaling Regulation. ChemBioChem 2019, 20, 7-19.

[91] Roncaroli, F.; van Eldik, R.; Olabe, J. A. Release of NO from Reduced Nitroprusside Ion. Iron-Dinitrosyl Formation and NO-Disproportionation Reactions. Inorg. Chem. 2005, 44, 2781-2790.

[92] Butler, A. R.; Megson, I. L. Non-Heme Iron Nitrosyls in Biology. Chem. Rev. 2002, 102, 1155-1165.

[93] Lorkovic, I.; Ford, P. C. Nitric Oxide Addition to the Ferrous Nitrosyl Porphyrins Fe(P)(NO) Gives trans-Fe(P)(NO) in Low-Temperature Solutions. J. Am. Chem. Soc. 2000, 122, 6516-6517.

[94] Conradie, J.; Wondimagegn, T.; Ghosh, A. Molecular Structure and Conformation of Dinitrosylheme. J. Am. Chem. Soc. 2003, 125, 4968-4969.

[95] Martí, M.; Capece, L.; Crespo, A.; Doctorovich, F.; Estrin, D. A. Nitric Oxide Interaction with Cytochrome c' and its Relevance to Guanylate Cyclase. Why Does the Iron Histidine Bond Break? J. Am. Chem. Soc. 2005, 127, 7721-7728.

[96] Videla, M.; Roncaroli, F.; Slep, L. D.; Olabe, J. A. Reactivity of Reduced Nitroprusside, $\left[\mathrm{Fe}(\mathrm{CN})_{5} \mathrm{NO}^{3-}\right]^{3-}$ toward Oxygen. J. Am. Chem. Soc., 2007, 129, 278-279.

[97] Levin, N.; Osa Codesido, N.; Bill, E.; Weyhermüller, T.; Segantin Gaspari, A. P.; Santana da Silva, R.; Olabe, J. A.; Slep, L. D. Structural, Spectroscopìc, and Photochemical Investigation of an Octahedral NO-Releasing $\{\text { RuNO }\}^{7}$ Species. Inorg. Chem. 2016, 55, 7808-7810.

[98] Armor, J. N.; Hoffman, M. Z. Reactivity of coordinated nitrosyls. IV. One-electron reactivity of ruthenium(III) nitrosylpentaammine ion in aqueous solution. Inorg. Chem. 1975, 14, 444-446.

[99] Videla, M.; Jacinto, J. S.; Baggio, R.; Garland, M. T.; Singh, P.; Kaim, W.; Slep, L. D.; Olabe, J. A. New Ruthenium Nitrosyl-Complexes with Tris(1-pyrazolyl)methane (tpm) and 2,2'-Bipyridine (bpy) Coligands. Structure, Spectroscopy, Electrophilic and Nucleophilic Reactivities of Bound Nitrosyl. Inorg. Chem. 2006, 45, 8608-8617.

${ }_{[100]}$ Osa Codesido N.; De Candia, A. G.; Weyhermüller, T.; Olabe, J. A.; Slep, L. D. An electron-rich $\{\text { RuNO }\}^{6} \operatorname{complex:~}$ trans-[Ru(DMAP $\left.)_{4}(\mathrm{NO})(\mathrm{OH})\right]^{2+}\left(\mathrm{DMAP}=4-\mathrm{N}, \mathrm{N}^{\prime}(\right.$ dimethylaminopyridine $)$. Structure and reactivity. Eur. J. Inorg. Chem., 2012, 4301-4309.

[101] Tejero, J.; Hunt, A. P.; Santolini, J.; Lehnert, N.; Stuehr, D. J. Mechanism and regulation of ferrous heme-nitric oxide (NO) oxidation in NO synthases. J. Biol. Chem. 2019, 294, 7904-7916. 



Reactivity of Low-Spin $\{\mathrm{FeNO}\}^{8}$ Porphyrin Model Complexes: New Insight from a Bis-Picket Fence Porphyrin. Inorg. Chem. 2013, 52, 7766-7780.

[103] Weaver, D. L.; Snyder, D. A. Crystal and molecular structure of trans-chloronitrosylbis(ethylenediamine)cobalt(III) perchlorate. Inorg. Chem. 1970, 9, 2760-2767.

[104] Grande,L.M.; Noll, B.C.; Oliver,A.G.; Scheidt, W.R. Dynamics of NOMotion in Solid-State[Co(tetraphenylporphinato) (NO)]. Inorg. Chem. 2010, 49, 6552-6557.

${ }_{[105]} \mathrm{Hu}, \mathrm{B}$; $\mathrm{Li}$, J. One Electron Makes Differences: From Heme $\{\mathrm{FeNO}\}^{7}$ to $\{\mathrm{FeNO}\}^{8 .}$ Angew. Chem. Int. Ed. 2015, 52, 10579-10582.

[106] Montenegro, A. C.; Amorebieta, V. T.; Slep, L. D.; Martín, D. F.; Roncaroli, F.; Murgida, D. H.; Bari, S. E.; Olabe, J. A. Three Redox States of Nitrosyl: $\mathrm{NO}^{+}, \mathrm{NO}^{*}$ and $\mathrm{NO}^{-} / \mathrm{HNO}$ Interconvert Reversibly on the Same Pentacyanoferrate(II) Platform. Angew. Chem. Int. Ed. 2009, 48/23, 4213-4216.

[107] Montenegro, A. C.; Bari, S. E.; Olabe, J. A. Reactivity of iron(II)-bound nitrosyl hydride (HNO, nitroxyl) in aqueous solution. J. Inorg. Biochem. 2013, 118, 108-114.

${ }_{[108]}$ Sellmann, D.; Gottschalk-Gaudig, T.; Haussinger, D.; Heinemann, F. W.; Hess, B. A. $\left[\operatorname{Ru}(H N O)\left({ }^{\prime}\right.\right.$ py $\left.\left.^{\text {bu }} \mathrm{S}_{4}{ }^{\prime}\right)\right]$, the First HNO Complex Resulting from Hydride Addition to a NO Complex ('py ${ }^{\text {bu }} \mathrm{S}_{4}{ }^{2-}=2,6-\mathrm{Bis}(2$-mercapto- 3,5-di-tertbutylphenylthio)dimethylpyridine(2-)). Chem. Eur. J. 2001, 7, 2099-2103.

${ }_{[109]}$ Lee, J.; Richter-Addo, G. B. A nitrosyl hydride complex of a heme model $[\mathrm{Ru}(\mathrm{ttp})(\mathrm{HNO})(1-\mathrm{MeIm})](\mathrm{ttp}=$ tetratolylporphyrinato dianion). J. Inorg. Biochem. 2004, 98, 1247-1250.

[110] Wilson, R. D.; Ibers, J. A. Coordinated nitrosyl hydride: structural and spectroscopic study of dichlorocarbonyl(nitrosyl hydride)bis(triphenylphosphine)osmium(II). Inorg. Chem. 1979, 18, 336-343.

[111] Gao, Y.; Toubaei, A.; Kong, X.; Wu, G. Acidity and Hydrogen Exchange Dynamics of Iron(II)-Bound Nitroxyl in Aqueous Solution. Angew. Chem. 2014, 126, 11731-11735.

[112] Lin, R.; Farmer, P. J. The HNO Adduct of Myoglobin: Synthesis and Characterization. J. Am. Chem. Soc. 2000, 122, 2393-2394.

[113] Goodrich, L. E.; Lehnert, N. The trans effect of nitroxyl (HNO) in ferrous heme systems: Implications for soluble guanylate cyclase activation by HNO. J. Inorg. Biochem. 2013, 118, 179-186.

[114] Mazzeo, A.; Pellegrino, J.; Doctorovich, F. Water-Soluble Nitroxyl Porphyrin Complexes Fe ${ }^{\mathrm{II} T P P S H N O}$ and $\mathrm{Fe}^{\mathrm{II}}$ TPPSNO- Obtained from Isolated Fe ${ }^{\mathrm{II}} \mathrm{TPPSNO}$. J. Am. Chem. Soc. 2019, 141, 18521-18530.

\section{Bio}

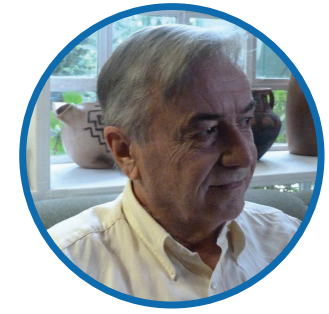

\section{José A. Olabe}

José A. Olabe was born in San Sebastián (Spain), and performed undergraduate, doctoral and postdoctoral studies at La Plata
University (Argentina). He was a Visiting Professor at SUNY, Stony Brook, and is an Emeritus Professor at the University of Buenos Aires. As a member of the National Research Council, his research interest deals with the coordination chemistry of small nitrogenated molecules to biologically relevant transition metal centers, with emphasis on the kinetic and mechanistic properties. 